Florida International University FIU Digital Commons

\title{
Design of Low Impact Development and Green Infrastructure at Flood Prone Areas in the City of Miami Beach, FLORIDA, USA
}

Noura Alsarawi

nalsa003@fiu.edu

DOI: $10.25148 /$ etd.FIDC006897

Follow this and additional works at: https://digitalcommons.fiu.edu/etd

Part of the Civil Engineering Commons, Environmental Design Commons, Environmental Engineering Commons, Sustainability Commons, Urban, Community and Regional Planning Commons, and the Water Resource Management Commons

\section{Recommended Citation}

Alsarawi, Noura, "Design of Low Impact Development and Green Infrastructure at Flood Prone Areas in the City of Miami Beach, FLORIDA, USA" (2018). FIU Electronic Theses and Dissertations. 3739.

https://digitalcommons.fiu.edu/etd/3739 


\section{FLORIDA INTERNATIONAL UNIVERSITY}

Miami, Florida

DESIGN OF LOW IMPACT DEVELOPMENT AND GREEN INFRASTRUCTURE AT FLOOD PRONE AREAS IN THE CITY OF MIAMI BEACH, FLORIDA, USA

A thesis submitted in partial fulfillment of

the requirements for the degree of

MASTER OF SCIENCE

in

ENVIRONMENTAL ENGINEERING

by

Noura Alsarawi 
To: Dean John L. Volakis

College of Engineering and Computing

This thesis, written by Noura Alsarawi, and entitled Design of Low Impact Development and Green Infrastructure at Flood Prone Areas in the City of Miami Beach, Florida, USA, having been approved in respect to style and intellectual content, is referred to you for judgement.

We have read this thesis and recommend that it be approved.

Walter Tang

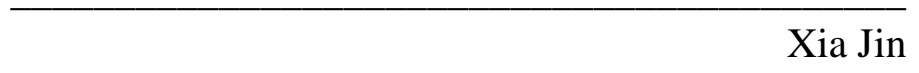

Xia Jin

Hector R. Fuentes, Major Professor

Date of Defense: June 29, 2018

The thesis of Noura Alsarawi is approved.

Dean John L. Volakis
College of Engineering and Computing

College of Engineering and Computing

Andrés G. Gil

Vice President for Research and Economic Development and Dean of the University Graduate School

Florida International University, 2018 


\section{DEDICATION}

This thesis is dedicated to my loving parents

\section{Mohammed Alsarawi}

$\&$

Muna Alrefaei

without you, none of my success would be possible. 


\section{ACKNOWLEDGMENTS}

I would like to extend my sincere gratitude to my major advisor Professor Hector R. Fuentes. I am proud and honored to have had the privilege of completing my Master's Degree under your guidance and supervision. Your passion in this field of study has always been an inspiration. Thank you for your brilliant comments, suggestions, and the hours' worth of brainstorming. Words cannot explain how grateful I am.

I would also like to thank my committee members, Professor Xia Jin and Professor Walter Tang. Professor Jin's contribution to this thesis started in the GIS for Civil and Environmental Engineering lecture hall. Without your excellent teaching and mentoring skills, this thesis would not be possible. Professor Tang's insightful comments and suggestions have opened my eyes to exploring new and innovative ideas.

I would like to extend my gratitude to the Kuwait Ministry of Higher Education for sponsoring my studies and giving me the opportunity to get the best education possible. I will be forever grateful. Special thanks to Mr. Robert Dickinson from Innovyze for his technical support and his informative insightful blogs. I would also thank my dear friend Mr. Carlos Tamayo for helping me whenever I needed his expertise. Special thanks to Dr. Sheyla Santana from the FIU GIS Center for helping me with GIS data.

To my parents, Mohammed Alsarawi and Muna Alrefaei, thank you for encouraging me in all my pursuits and for inspiring me to follow my dreams. To my siblings, Khalid, Ranya, and Abdulrahman, thank you for your endless support and for always being there for me. To my friends, Muzun Alshenaifi and Alaa Alanezi, thank you for listening, offering me advice, and supporting me throughout this entire process. 


\begin{abstract}
OF THE THESIS
DESIGN OF LOW IMPACT DEVELOPMENT AND GREEN INFRASTRUCTURE

AT FLOOD PRONE AREAS IN THE CITY OF MIAMI BEACH, FLORIDA, USA

by
\end{abstract}

Noura Alsarawi

Florida International University, 2018

Miami, Florida

Professor Hector R. Fuentes, Major Professor

This thesis investigates the effectiveness of Low Impact Development Infrastructure (LIDI) and Green Infrastructure (GI) in reducing flooding resulting from heavy rainfall events and sea-level rise, and in improving stormwater quality in the City of Miami Beach (CMB). InfoSWMM was used to simulate the 5, 10, and 100-year, 24-hour storm events, total suspended solids (TSS), biochemical oxygen demand (BOD), and chemical oxygen demand (COD) loadings, and in evaluating the potential of selected LIDI and GI solutions in North Shore neighborhood.

Post-development results revealed a decrease of $48 \%, 46 \%$, and $39 \%$ in runoff, a decrease of $57 \%, 60 \%$, and $62 \%$ in TSS, a decrease of $82 \%, 82 \%$, and $84 \%$ in BOD, and a decrease of $69 \%, 69 \%$, and $70 \%$ in COD loadings. SWMM 5.1 was also used to simulate the king tide effect in a cross section in Indian Creek Drive. The proposed design simulations successfully demonstrated the potential to control flooding, showing that innovative technologies offer the city opportunities to cope with climate impacts. This study should be most helpful to the CMB to support its management of flooding under any adaptation scenarios that may possibly result from climate changes. Flooding could be again caused as a result of changes in inland flooding from precipitation patterns or from sea-level rise or both. 


\section{TABLE OF CONTENTS}

CHAPTER

PAGE

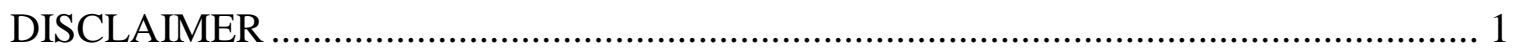

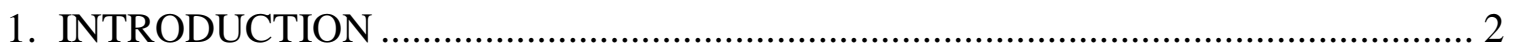

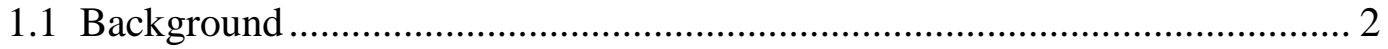

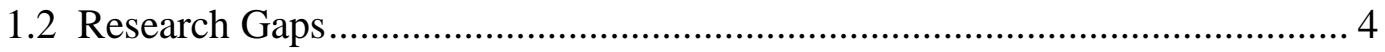

1.3 Central Hypothesis and Research Objectives ............................................... 5

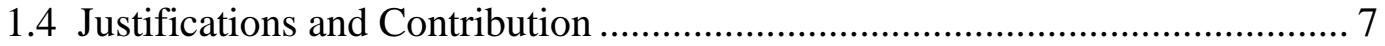

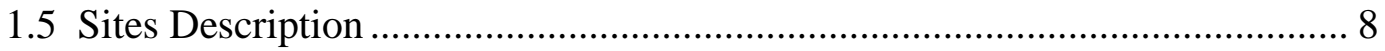

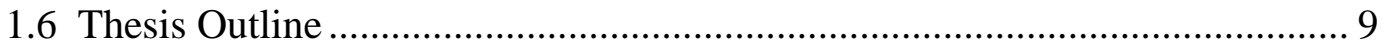

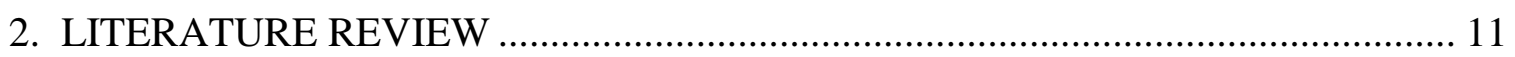

2.1 The Effects of Urbanization on Stormwater Quality and Quantity ............... 11

2.2 Low Impact Development and Green Infrastructure Advantages .................. 13

2.3 Low Impact Development and Green Infrastructure Success Stories ........... 16

2.3.1 Sustainable Drainage System in Cambourne Village, England...... 16

2.3.2 Bioswales in Boronda Crossing Shopping Center in Northwestern

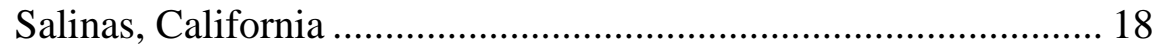

2.3.3 Rainwater Harvesting, Bioretention Swales, and Pervious Pavement in Bronx River Watershed in New York City, New York ............................................................................. 18

2.3.4 Permeable Pavement in St. Louis, Missouri .................................... 19

2.3.5 Blue roof and Green Blue Roof in Seoul Metropolitan Area,

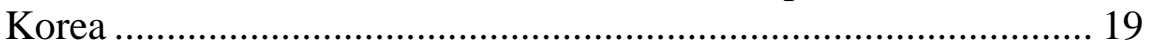

2.4 Model Theory and Specifications ............................................................ 20

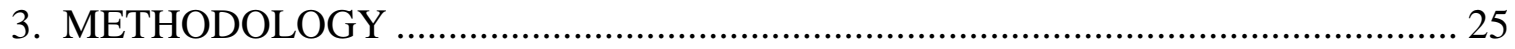

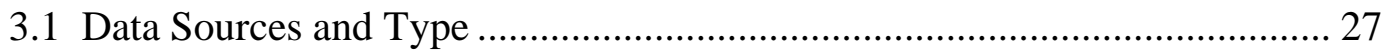

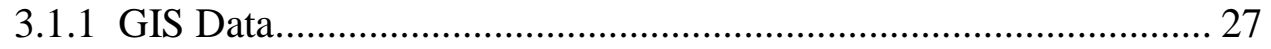

3.1.2 Meteorological Data.................................................................. 28

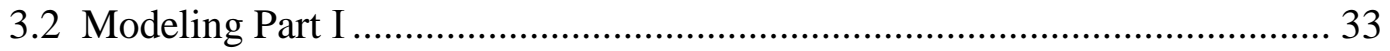

3.2.1 Ground Characteristics................................................................ 34 
3.2.2 Low Impact Development and Green Infrastructure Siting

Criteria. 36

3.3 Modelling Part II

3.3.1 North Shore Study Site Subcatchment Characteristics and Simulation Options ............................................................................ 40

3.3.2 Soil Characteristics and Green-Ampt Infiltration Parameters ........ 41

3.3.3 Water Quality Simulation ............................................................. 41

3.3.4 Low Impact Development and Green Infrastructure Design Parameters and Considerations ...................................................... 42

3.3.4.1 Bioretention Cell Proposed Solution ............................. 43

3.3.4.2 Green Roof Proposed Solution ..................................... 45

3.3.4.3 Grassed Swale Proposed Solution ................................ 46

3.3.4.4 Rain Barrel Proposed Solution ....................................... 47

3.3.4.5 Pervious Concrete Proposed Solution ........................... 47

3.3.5 Low Impact Development and Green Infrastructure

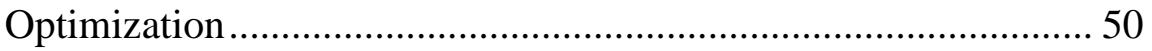

3.4 EPA SWMM 5.1 Modeling of Indian Creek Drive Location ......................... 50

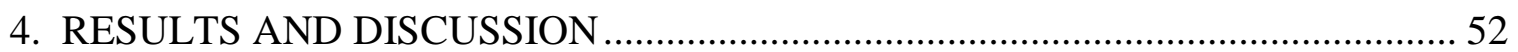

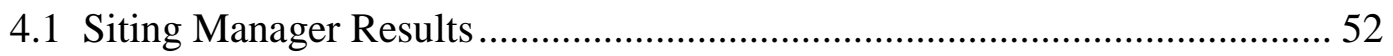

4.1.1 Flamingo Lummus Neighborhood ................................................ 53

4.1.2 South Pointe Neighborhood .......................................................... 54

4.1.3 City Center Neighborhood ............................................................. 54

4.1.4 Bayshore Neighborhood ............................................................. 55

4.1.5 North Shore Neighborhood.......................................................... 57

4.2 Pre-development Scenario Results ............................................................ 57

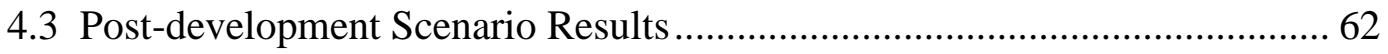

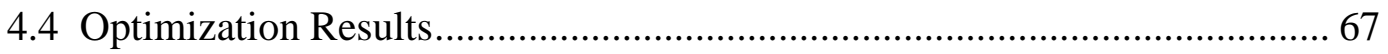

4.5 EPA SWMM 5.1 Modeling Results of Indian Creek Drive Location ............ 70

5. CONCLUSIONS, ASSUMPTIONS AND LIMITATIONS, AND

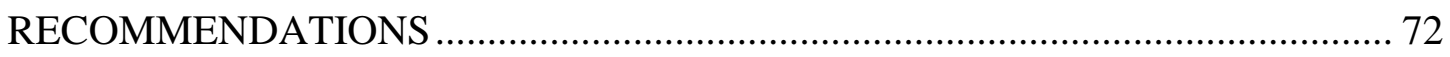

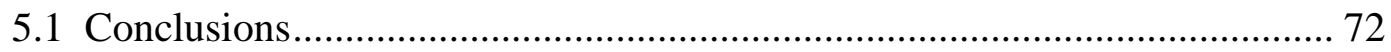

5.2 Assumptions and Limitations ....................................................................... 73 


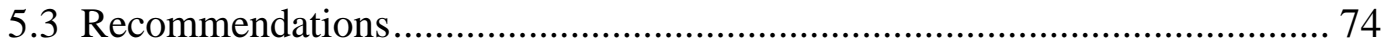

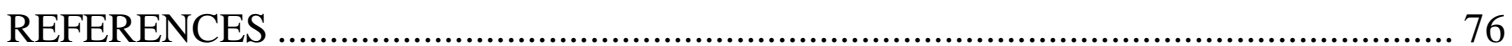

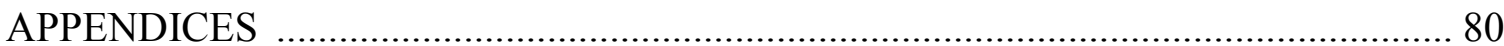




\section{LIST OF TABLES}

TABLE

PAGE

2-1. Typical Pollutant Loadings (lb/acre-yr) from Different Land Uses .......................... 13

2-2. Cost Comparison Between LIDI/GI and Gray Infrastructure …………………........ 16

2-3. Comparison of InfoSWMM and SWMM 5.1 Capabilities ......................................2 24

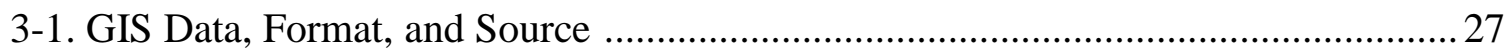

3-2. Calculated 5-year, 24-hour Storm Event Cumulative Depths and Average

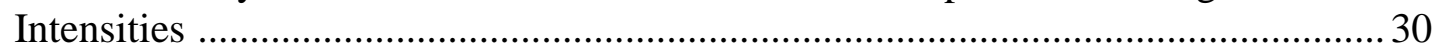

3-3. Calculated 10-year, 24-hour Storm Event Cumulative Depths and Average Intensities

3-4. Calculated 100-year,24-hour Storm Event Cumulative Depths and Average Intensities 32

3-5. Recommended Ground Conditions for LIDI and GI Placement .............................. 38

3-6. LIDI and GI Design Parameters ...................................................................... 49

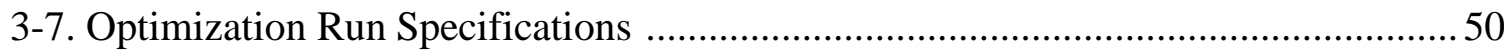

4-1. Pre-development 5-year, 24-hour Storm Event Continuity

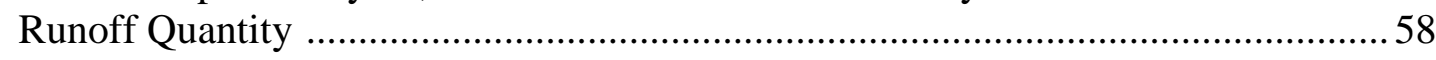

4-2. Pre-development 5-year, 24-hour Storm Event Continuity

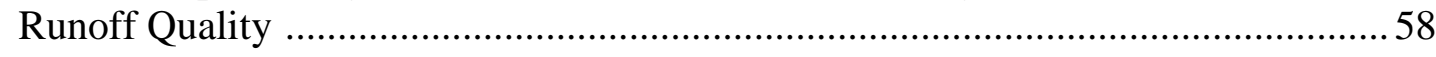

4-3. Pre-development 10-year, 24-hour Storm Event Continuity Runoff Quantity 59

4-4. Pre-development 10-year, 24-hour Storm Event Continuity Runoff Quality 59

4-5. Pre-development 100-year, 24-hour Storm Event Continuity Runoff Quantity 60

4-6. Pre-development 100-year, 24-hour Storm Event Continuity Runoff Quality 60

4-7. Post-development 5-year, 24-hour Storm Event Continuity 
Runoff Quantity

4-8. Post-development 5-year, 24-hour Storm Event Continuity

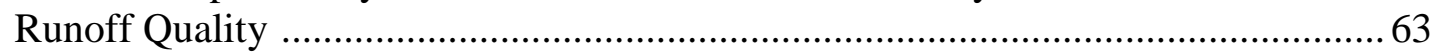

4-9. Post-development 10-year, 24-hour Storm Event Continuity Runoff Quantity 64

4-10. Post-development 10-year, 24-hour Storm Event Continuity Runoff Quality 64

4-11. Post-development 100-year, 24-hour Storm Event Continuity Runoff Quantity 65

4-12. Post-development 100-year, 24-hour Storm Event Continuity Runoff Quality 65

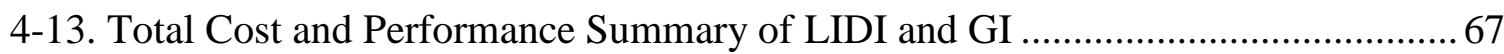

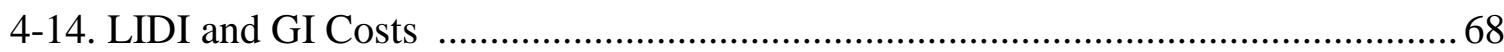

4-15. Dual BMP System Effectiveness in Controlling King Tide Flooding ................... 70 


\section{LIST OF FIGURES}

FIGURE

PAGE

1-1. The City of Miami Beach Flood Risk Level ……………......................................... 3

1-2. (A) Top View Image of the Indian Creek Drive Site (B) Cross Section of the Current Project Site .............................................................................. 8

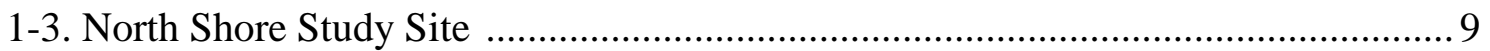

2-1. Effect of Urbanization on the Natural Hydrologic Cycle ...................................... 11

2-2. Lamb Drove Sustainable Drainage System Proposal ......................................... 17

2-3. Comparison of Water Discharge Pre and Post-development ................................. 17

2-4. Comparison of Water Quality Constituents Pre and Post-development................... 17

2-5. Processes Considered in the EPA SWMM 5.1 Model ........................................ 20

2-6. EPA SWMM 5.1 Nonlinear Reservoir Method .................................................. 22

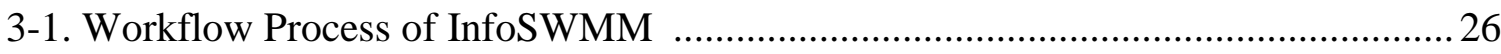

3-2. 5-year, 24-hour Design Storm Hyetograph .................................................. 30

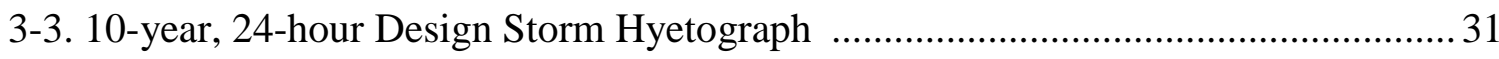

3-4. 100-year, 24-hour Design Storm Hyetograph .............................................. 32

3-5. City of Miami Beach Neighborhoods Map .................................................... 33

3-6. Specifying Ground Conditions in the Siting Manager ....................................... 35

3-7. (A) Land Use Code Field (B) Urban Land Use Type Field (C) Soil Code Field (D) Land Ownership Field ................................................................ 35

3-8. LIDI and GI Siting Criteria for (A) Green Roof (B) Bioretention Cell (C) Porous Pavement (D) Grassed Swale (E) Infiltration Trench (F) Sand Filter

(G) Constructed Wetland (H) Rain Barrel ........................................................ 39

3-9. Bioretention Cell Proposed Solution ............................................................. 44

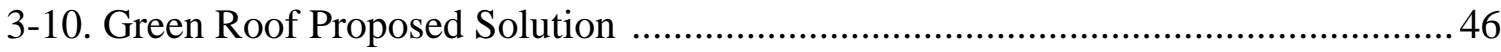




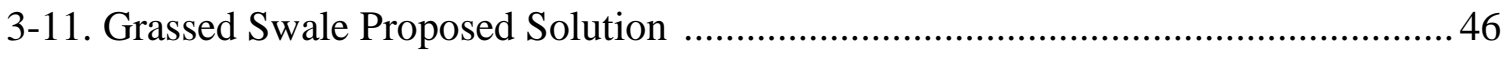

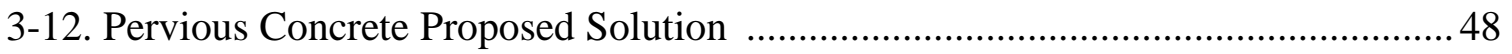

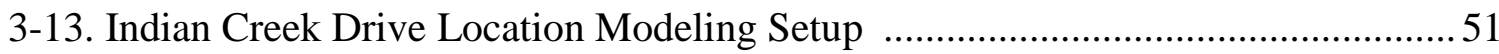

4-1. Flamingo Lummus Neighborhood Siting Results ...........................................53

4-2. South Pointe Neighborhood Siting Results .................................................... 54

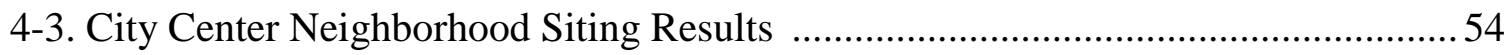

4-4. Bayshore Neighborhood Siting Results Part I ............................................... 55

4-5. Bayshore Neighborhood Siting Results Part II ..................................................56

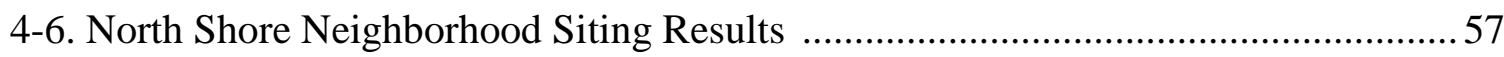

4-7. Pre-development 5-year, 24-hour Rainfall-Runoff Graph .................................. 58

4-8. Pre-development 10-year, 24-hour Rainfall-Runoff Graph ..................................59

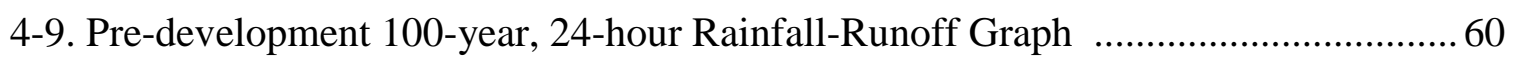

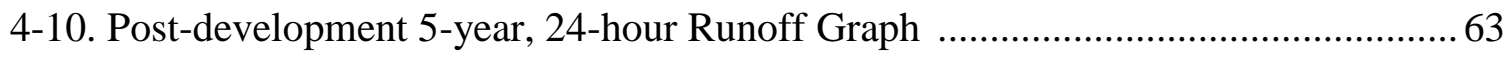

4-11. Post-development 10-year, 24-hour Runoff Graph ............................................ 64

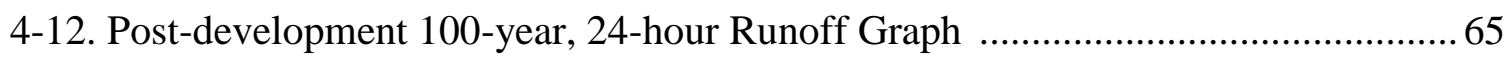

4-13. Indian Creek Drive Dual BMP Proposed Solution .......................................... 71 


\section{ABBREVIATIONS AND ACRONYMS}

\begin{tabular}{ll} 
BMP & Best Management Practices \\
BOD & Biochemical Oxygen Demand \\
COD & Chemical Oxygen Demand \\
CMB & City of Miami Beach \\
CN & Curve Number \\
EPA & Environmental Protection Agency \\
EMC & Event Mean Concentration \\
FEMA & Federal Emergency Management Agency \\
GIS & Geographic Information System \\
GI & Green Infrastructure \\
GHG & Greenhouse Gasses \\
HSG & Hydrologic Soil Group \\
IDF & Intensity-Duration-Frequency \\
LIDI & Low Impact Development Infrastructure \\
NLCD & National Land Cover Database \\
NRCS & National Resource Conservative Services \\
NSGA-II & Non-dominated Sorting Genetic Algorithm \\
NAVD 88 & North American Vertical Datum 1988 \\
SWMM & Stormwater Management Model \\
TSS & Total Suspended Solids \\
UHI & Urban Heat Island \\
\hline &
\end{tabular}




\section{DISCLAIMER}

This thesis was prepared as a part of Master's degree completion at Florida International University. The author, Professor Hector R. Fuentes, the department of Civil and Environmental Engineering, Florida International University, and all sources referenced in this research:

1. Do not guarantee the accuracy of all scenarios and simulations that were created and evaluated, their cost estimation, conclusions, recommendations, content of this study and used references.

2. Do not guarantee the completeness of the information contained in this research or represent that its use would not infringe upon privately owned rights.

3. Do not assume liability or responsibility of any consequential damages from the use of any information, method or process presented in this research, which should be used considered within the scope, assumptions and limitations of the investigation and study.

In addition, this thesis does not reflect the official views or policies of any sponsoring, participating or contributing organizations and individuals. 


\section{INTRODUCTION}

\subsection{Background}

Flood events in the City of Miami Beach (CMB) have significantly increased over the last decade. The increased flooding is part of an acceleration of sea-level rise and storm surges during hurricane seasons in coastal cities in Southeast Florida. These frequent flood events occur mainly due to heavy rainfall events and exceptionally high tide conditions. According to the international disaster database, of all the disaster types in the United States, flooding ranks first in frequency and second in fatalities [1]. In fact, $80 \%$ of hurricane related fatalities occurred outside of the storm surge zone and are caused by inland flooding [2]. According to the Southeast Florida regional climate change sea level rise work group, sea-level rise is projected to be 6 to 10 inches by 2030 , 14 to 26 inches by 2060, and 31 to 61 inches by 2100 [3]. In addition, the counties of Palm Beach, Broward and Miami-Dade are affected by at least three types of floods because they are located in the southeastern corner of Florida; (a) storm surge flooding in coastal areas, (b) flash floods due to heavy downpours during storms, and (c) when water bodies, such as rivers, canals and lakes overflow [1]. The flat topography of Florida and the fact that the $\mathrm{CMB}$ consists of natural and man-made barrier islands prioritize the need of controlling rain-induced flooding to avoid major coastal flooding hazards especially when high tide conditions occur. According to the Federal Emergency Management Agency (FEMA), all properties within the CMB are located in or near a special flood hazard area (Figure 1-1). Therefore, all properties are vulnerable to flooding. Recently, the City of Miami has been identified as the economically most vulnerable city to sealevel rise in the world [4]. 


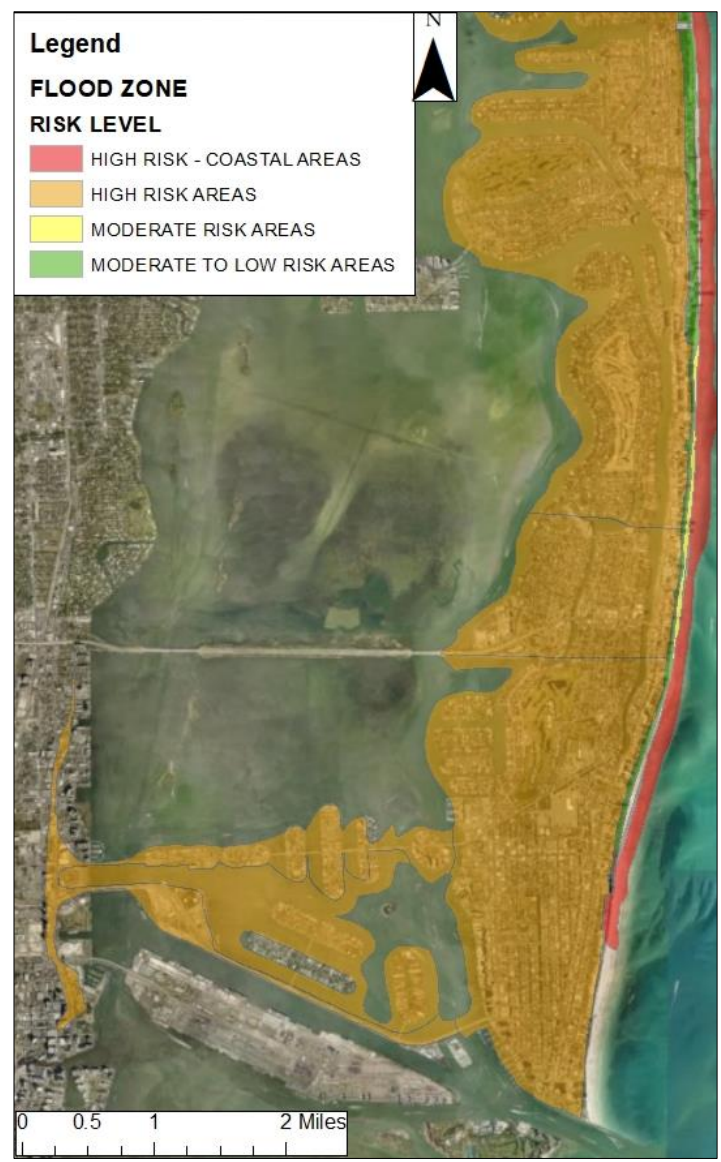

Figure 1-1. The City of Miami Beach Flood Risk Level (Flood Zone GIS Data [5], Background Map [6])

The CMB is almost completely urbanized. Urbanization increases surface runoff during storm events and degrades water quality, which can result in more frequent and severe flooding, habitat loss, property deterioration, and damage to human and ecosystem communities [7]. Urban areas can greatly affect the natural drainage system as increasing the amount of impervious surfaces reduces the ability of rainwater to infiltrate, and therefore, results in increasing runoff volume. In addition, as water flows over the impervious areas, it carries all kinds of contaminants; sediment, chemicals, bacteria, viruses, and other pollutants are carried into receiving waterbodies resulting in degraded water quality. The introduction of contaminants of physical, chemical, and biological 
origin resulting from various anthropogenic activities common in urban areas [8] coupled with the increased runoff from urbanization is a leading cause of nonpoint source pollution [9].

Urbanization is often an issue in tourist destination cities, yet it is a very important factor for a thriving economy. A modern solution for overcoming flood related problems is the design and implementation of Low Impact Development Infrastructure (LIDI) and Green Infrastructure (GI). Jurries (2003) defines LIDI as a stormwater management strategy aimed at maintaining or restoring the natural hydrologic functions of watersheds by employing development features that reduce the rate of runoff, filter pollutants, and facilitate groundwater infiltration [10]. When water accumulates on the surface during a heavy rainfall event, it floods the area, disturbs the city and its residents, and accumulates contaminants that will find their ways into receiving waterbodies. To overcome these problems and treat stormwater as a resource rather than a waste product, LIDI and GI are implemented to mimic natural processes that result in infiltration, evapotranspiration, groundwater recharge, or water recycling to protect water quality and control flooding.

\subsection{Research Gaps}

Much research has been conducted around designing and implementing LIDI and GI to reduce runoff, and to collect stormwater for the purpose of recycling or groundwater recharge. However, previous research targeted rain-induced flooding; not flooding resulting from sea-level rise. Sea-level rise flooding is known as "sunny day flooding” occurring mainly in low-lying coastal cities. For sunny day flooding occurrences, research has been done on the feasibility, effectiveness and construction of 
gray infrastructure, such as building dikes and dams to control flooding, but without the possibility of improving stormwater quality. In some cases, these controls could cause harm more than help; artificial coastal structures, along with their construction and maintenance, have had a variety of effects on the geomorphology and ecology of coastal systems [11]. For instance, these structures often interfere with the spatial dynamics of sediment transport, salinity, and animal movement or reproduction [11]. On the other hand, LIDI and GI are relatively harmless, and researching their feasibility and effectiveness in controlling sunny day flooding could be a major benefit to vulnerable cities. In addition, previous research objectives have been mainly to investigate the effectiveness of the LIDI or GI designs in reducing stormwater flooding and pollution for randomly chosen locations, or locations that have been suffering from frequent flooding. However, in this research, most of the CMB will be tested based on suitability criteria for LIDI and GI placement so as to provide a complete guide for the most suitable locations to implement the designs. Each type of LIDI and GI is unique, therefore performing sitespecific ground condition suitability analysis and placement criteria is crucial to ensure the long-term effectiveness of the design.

\subsection{Central Hypothesis and Research Objectives}

The central hypothesis is that the designed LIDI and GI solutions will control and reduce the frequent flood events in the $\mathrm{CMB}$ resulting from heavy rainfall events and sealevel rise and improve stormwater quality by reducing significant amounts of total suspended solids (TSS), biochemical oxygen demand (BOD), and chemical oxygen demand (COD). 
The research objectives of this study are to develop a series of hydrologichydraulic software models (i.e., SWMM) to evaluate the potential LIDI and GI solutions or both, as selected for this case study, to control flooding and improve its water quality in the CMB. The objectives are:

1. Establish a comprehensive plan of suitable sites for placing LIDI and GI according to suitability criteria for the CMB.

2. Test designs of LIDI and GI solutions that will control and reduce flooding as a result of heavy rainfall events and sea-level rise in the CMB.

3. Test the effects of the same LIDI and GI designs on the improvement of water quality of flowing waters.

Examples of LIDI are pervious pavement, rain barrels, and infiltration trenches. In this research, the term LIDI will be referring to land redevelopment or land retrofitting designs aimed to minimize imperviousness and provide additional storage to control and reduce stormwater flooding and protect its water quality by capturing runoff as close to its source as possible. On the other hand, GI refers to aesthetically pleasing areas designed mostly using natural materials (e.g. trees, grass, soil, organic matter, and gravel) to mimic natural processes that result in infiltration, evapotranspiration, and groundwater recharge to control and reduce runoff and improve stormwater quality. In addition to its stomwater management capabilities, GI provides ecological benefits as well, such as reducing the urban heat island effect $(\mathrm{UHI})$, storing carbon dioxide, reducing energy demands, and preserving/creating natural habitat functions. It captures and treats runoff from parking lots, walkways/corridors, and streets. GI designs include rain gardens, bioretention cells, green roofs, and vegetative swales. Those designs could be 
implemented as a retrofitting project (e.g. converting a parking lot island into a bioretention cell or implementing a green roof on an existing building) or as a part of a new development project (e.g. developing a new sustainable community containing several types of GI).

Both LIDI and GI goal is to control and reduce stormwater runoff and improve its water quality. Choosing which design to implement depends on the specific site location, its physical characteristics (e.g. area, soil and ground conditions, and typography), and the desired reduction targets of stormwater runoff and water quality constituents. The strategy and steps that will ease the process of choosing the most suitable type of either LIDI or GI will be discussed in detail in this research.

\subsection{Justifications and Contribution}

Major cities in collaboration with The Southeast Florida Regional Climate Change Compact have been developing science-based applications to tackle the effects of Climate Change. The CMB is preparing a master plan for a neighborhood in North Miami Beach that has been experiencing the combined effects of sea-level rise and urbanization. This thesis will perform site-specific ground condition suitability analysis and placement criteria of LIDI and GI throughout the neighborhood to be considered in the master plan. Indian Creek Drive is under redevelopment and a solution for the location to tackle the frequent flood events resulting from elevated creek water levels will be included. In addition, the city is looking into developing a GI manual as an addition to the city's existing public works manual, LIDI and GI siting criteria and performance results will serve as a useful guide to set standards for construction. 


\subsection{Sites Description}

Indian Creek Drive has been under construction for a flooding mitigation project by the CMB. The drive is known for flooding during heavy rainfall events and annual king tides. The city partnered with the Florida Department of Transportation to reduce flooding in Indian Creek Drive by raising the seawall and upgrading the drainage system. However, the city is also interested in creating an aesthetically pleasing green solution that will contribute to this project in preventing flood events and improving water quality. This site is located on Indian Creek Drive 190 feet from $27^{\text {th }}$ Street. It is 20 feet wide and 200 feet long and specifically located between the drive and the creek (Figure 1-2 (A)). Indian Creek Drive is currently under construction and the current state of the site is presented in Figure 1-2 (B). Because of the recent implementation of the wall between the drive and the creek, runoff from the street was not considered as a design parameter. The LIDI and GI designs and parameters were modeled to accommodate flooding as a result of elevated water levels from the creek.
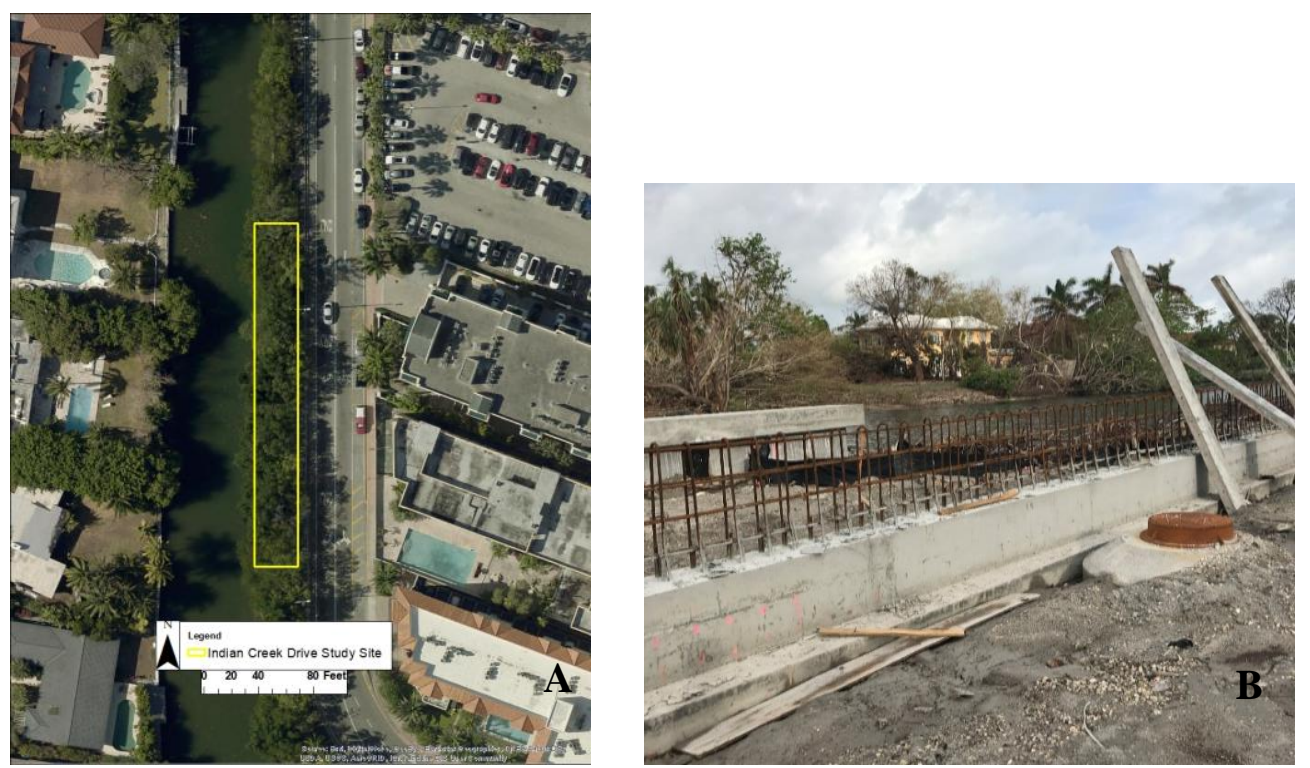

Figure 1-2. (A) Top View Image of the Indian Creek Drive Site (Background Map [12]) (B) Cross Section of the Current Project Site 
Informed input from personnel of the CMB indicated that the city is working on a master plan for neighborhoods in North Miami Beach and specifically in North Shore neighborhood to reduce flood events that have been affecting residents and interrupting their lifestyle. As a result, this area was chosen as the primary study site to investigate the effectiveness of implementing LIDI and GI on flood reduction and stormwater quality improvement. Figure 1-3 shows the study site boundaries in North Shore neighborhood.

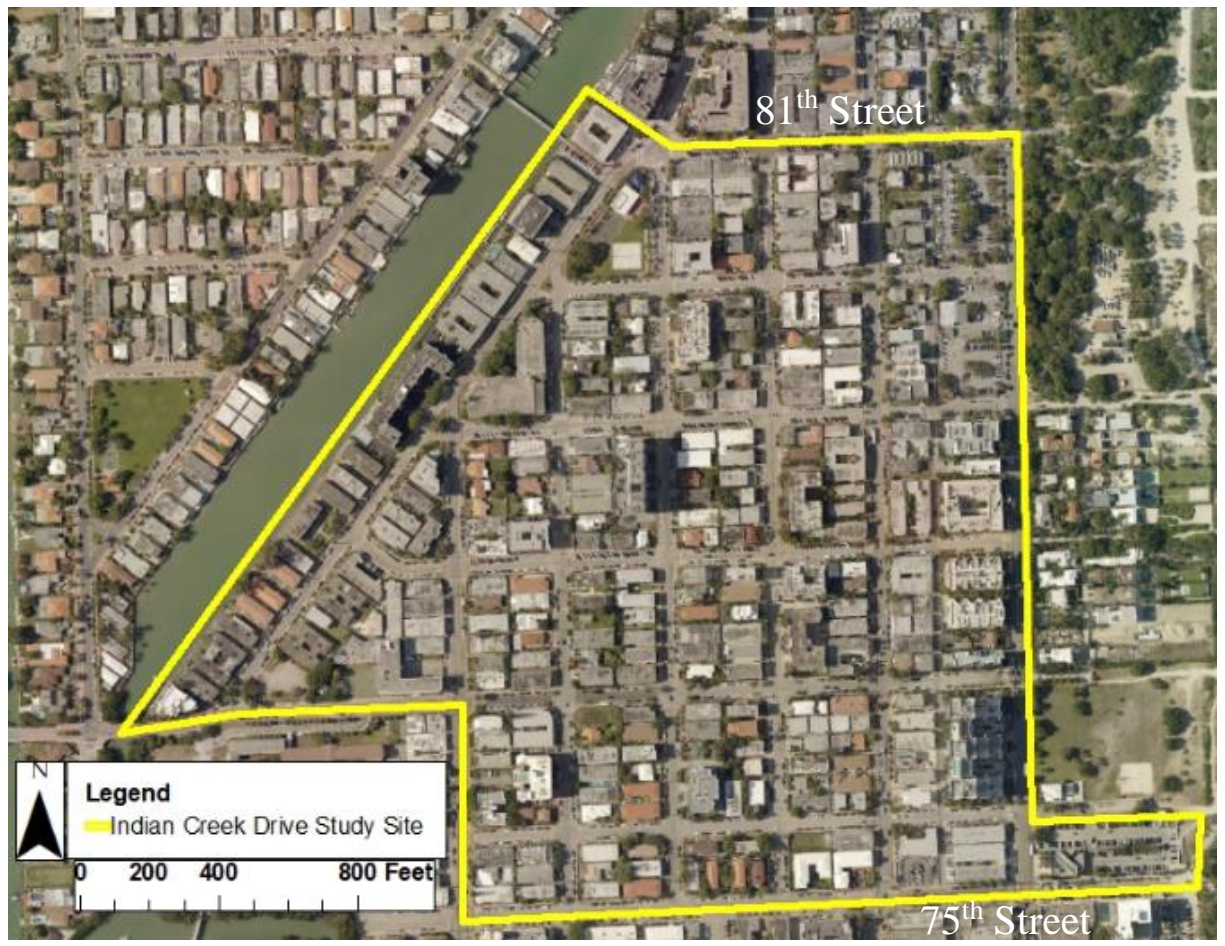

Figure 1-3. North Shore Study Sites (Background Map [12])

\subsection{Thesis Outline}

This thesis is organized in five chapters. The first chapter is the introduction, which includes background information on the $\mathrm{CMB}$, research gaps, central hypothesis and research objectives, a brief description on how this research is extremely beneficial to the $\mathrm{CMB}$ and other coastal cities suffering from sea-level rise and reoccurring high intensity rainfall events, and the location of the study sites. Chapter two is the literature 
review, in which extensive research has been done to discuss the effects of urbanization on stormwater quality and quantity, LIDI and GI advantages, LIDI and GI global case studies, and the Environmental Protection Agency (EPA) Stormwater Management Model version 5.1 (SWMM 5.1) and InfoSWMM SUSTAIN by Innovyze theory. Chapter three is the methodology used, which explains the organized step-by-step modeling approach that was used to conduct this research. In addition, it specifies the subcatchments characteristics, simulation options, soil characteristics, and water quality constituents and buildup and washoff methods. Moreover, chapter three lists LIDI and GI design parameters, and presents 3D sketches of the proposed solutions. Chapter four is the results and discussion addressing the objectives of this thesis. The LIDI and GI performance results are presented for runoff reduction and water quality enhancement and evaluated in comparison with pre-development stages. In addition, cost estimation for the optimized LIDI and GI solutions package are presented. Chapter five presents the conclusions, where key aspects from the literature and results are revisited, and recommendations and limitations are highlighted. 


\section{LITERATURE REVIEW}

\subsection{The Effects of Urbanization on Stormwater Quality and Quantity}

Urbanization replaces vegetative pervious surfaces with impervious ones thus altering the natural hydrologic cycle. Precipitation that would typically infiltrate may instead be forced to runoff, carrying contaminants to downstream ecosystems [13]. Urbanization can increase runoff volume and peak flows, as well as decrease evapotranspiration, reduce groundwater recharge, increase stormwater contamination, and create the UHI effect [14] [15]. Figure 2-1 shows the effect of urbanization at different imperviousness percentages on the hydrologic cycle.

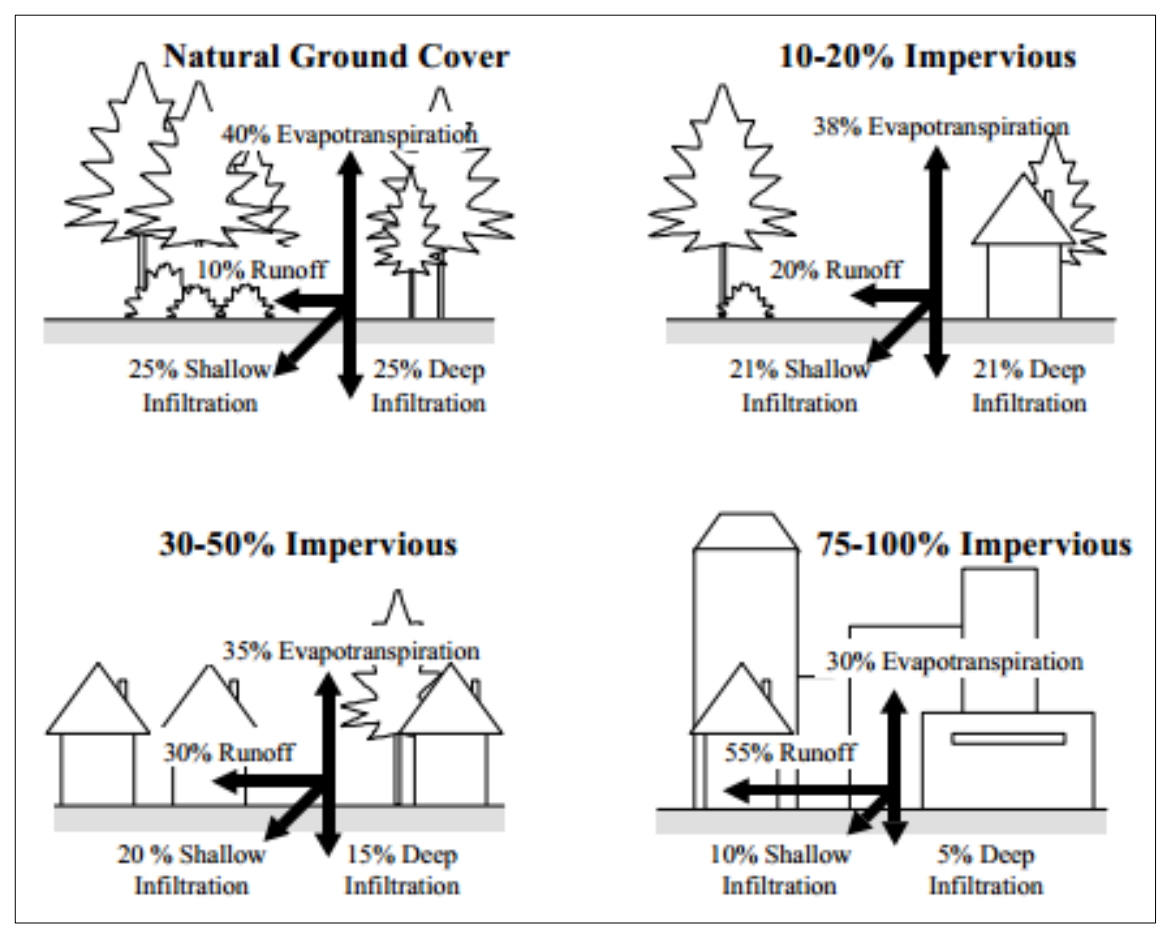

Figure 2-1. Effect of Urbanization on the Natural Hydrologic Cycle [16] July 10, 2017 at 10:00 am

Both the increasing quantity of stormwater runoff and the pollutant washoff from urban surfaces have degrading effects on the receiving waterbodies, including changes in 
the eco-hydrological diversity, deteriorating stream water quality, and stress in stream hydrology, due to higher peak discharges and shorter travel times [17]. When coupled with urbanization, environmental impacts of automobile emissions can cause severe harmful effects on stormwater quality. Research in 2010 reported that almost $30 \%$ of pollutants of urban runoff are derived from vehicle exhaust emission, vehicle tires, asphalt pavement, and paint markers, and are diffusely accumulated on road dust [18]. Urban runoff is considered dangerous as a result of the multiple land uses that stormwater can encounter before ending up in receiving waterbodies. In addition, recent monitoring has shown that much of urban runoff toxicity is linked to the current-use of pesticides [19]. As well as the multiple land use effect, there are a variety of natural and anthropogenic pollutants that can also degrade stormwater, such as pesticides and nutrients from grading, road salts from snow melting, toxic chemicals from automobiles, viruses and bacteria from pet waste, heavy metals from industrial activities and combustion processes.

To manage stormwater pollution, it is crucial to be able to predict pollution concentrations and loads generated from urban watersheds [20]. The national stormwater quality database (NSQD) is an urban stormwater runoff characterization database developed in 2001 by Dr. Robert Pitt, starting with support from the U.S. EPA. This database now includes the results and summary of a 10-year monitoring of stormwater runoff from more than 200 municipalities throughout the country [21]. Table 2-1 shows a summary of selected stormwater quality data included in NSQD. The table includes common urban runoff pollutants loading rates at each land use. 
Table 2-1. Typical Pollutant Loadings (lb/acre-yr) from Different Land Uses [21]

\begin{tabular}{|l|l|l|l|l|l|l|l|l|l|l|l|}
\hline Land-Use & TSS & TP & TKN & $\mathrm{NH}_{3}-\mathrm{N}$ & $\begin{array}{l}\mathrm{NO}_{2}-\mathrm{N} \\
\text { and } \\
\mathrm{NO}_{3}-\mathrm{N}\end{array}$ & $\mathrm{BOD}$ & $\mathrm{COD}$ & $\mathrm{Pb}$ & $\mathrm{Zn}$ & $\mathrm{Cu}$ & $\mathrm{Cd}$ \\
\hline Commercial & 1000 & 1.5 & 6.7 & 1.9 & 3.1 & 62 & 420 & 2.7 & 2.1 & 0.4 & 0.03 \\
\hline Parking Lot & 400 & 0.7 & 5.1 & 2.0 & 2.9 & 47 & 270 & 0.8 & 0.8 & 0.06 & 0.01 \\
\hline $\begin{array}{l}\text { High- } \\
\text { Density } \\
\text { Residential }\end{array}$ & 420 & 1.0 & 4.2 & 0.8 & 2.0 & 27 & 170 & 0.8 & 0.7 & 0.03 & 0.01 \\
\hline $\begin{array}{l}\text { Medium- } \\
\text { Density } \\
\text { Residential }\end{array}$ & 250 & 0.3 & 2.5 & 0.5 & 1.4 & 13 & 50 & 0.05 & 0.1 & 0.03 & 0.01 \\
\hline $\begin{array}{l}\text { Low- } \\
\text { Density } \\
\text { Residential }\end{array}$ & 65 & 0.04 & 0.3 & 0.02 & 0.1 & 1 & 7 & 0.01 & 0.04 & 0.01 & 0.01 \\
\hline Highway & 1700 & 0.9 & 7.9 & 1.5 & 4.2 & n/a & n/a & 4.5 & 2.1 & 0.37 & 0.02 \\
\hline Industrial & 670 & 1.3 & 3.4 & 0.2 & 1.3 & n/a & n/a & 0.2 & 0.4 & 0.10 & 0.05 \\
\hline $\begin{array}{l}\text { Shopping } \\
\text { Center }\end{array}$ & 440 & 0.5 & 3.1 & 0.5 & 1.7 & n/a & n/a & 1.1 & 0.6 & 0.09 & 0.01 \\
\hline
\end{tabular}

\subsection{Low Impact Development and Green Infrastructure Advantages}

The purpose of LIDI and GI is to mitigate the impact of land development to the environment [22]. LIDI and GI are designed to work with nature by managing stormwater as close to its source as possible for optimum results of runoff and contaminants reduction, water recycling, and groundwater recharge. When stormwater flows to the GI or when rainwater/runoff falls directly into LIDI, water can either be collected and recycled for irrigation purposes, or infiltrated through the native soil layers for the purpose of groundwater recharge. Common designs include bioretention swales, constructed wetlands, dry ponds, grassed swales, green roofs, infiltration basins, infiltration trenches, porous pavements, rain barrels, rain gardens, sand filters, vegetated strips, and wet ponds.

By mimicking natural hydrological processes, LIDI and GI reduce runoff from flooding the streets and entering receiving waterbodies through infiltrating, retaining, 
storing, and remediating stormwater runoff. They also serve the community by reducing the pressure from the sewer system and water treatment plants. LIDI improves stormwater quality through a combination of physical, chemical, and biological processes that occur through the LIDI designs [23]. Other than the positive impacts of LIDI and GI on stormwater quality and quantity described above in chapter 2.1, LIDI and analogous initiatives are successfully tested tools for providing political, ecological, societal, aesthetic, and psychological benefits for the community [23].

LIDI and GI are also common solutions to reduce the UHI effect and air pollution. UHI effects are felt in urban areas where concrete, tile and asphalt cause temperatures to rise above the regular city's temperature which causes increases in energy demands for cooling systems, air conditioning costs, and greenhouse gas emissions (GHG). If urban temperatures rise further due to the UHI effect and/or climate change, these problems would be exacerbated [24]. LIDI and GI can reduce UHI effects by shading surfaces to reduce energy consumptions in buildings. A New York experimental study on real roofs found that on average winter conductive heat loss through an insulated green roof was reduced by $20 \%$ and summer heat gains through the roof reduced by $60 \%$ when compared to a non-green roof [24]. LIDI and GI also contribute to reducing UHI effects through evapotranspiration from vegetation and soil to keep surfaces cool, and by reducing GHG emissions through deposition, absorption, and dispersion. These effects are well documented; "Surface temperatures within a green space can be $20^{\circ} \mathrm{C}$ lower than that of the surrounding urban area given rise to $2-8^{\circ} \mathrm{C}$ cooler air temperatures and a cooling effect that extends out to the surrounding areas [25]". 
The CMB has a high flooding potential as do the majority of cities in Florida. This is because of the different physical conditions in Florida, such as rainfall patterns, high groundwater table, and unique geology when compared to other states [26]. To adapt LIDI and GI for some parts of Florida with high groundwater table, detention with biofiltration and shallow biodetention have been developed to promote recharge to the shallow aquifers [27]. These LIDI and GI have been included in Florida's Statewide Treatment Rule, and embraced in several Florida counties [23]. Green roofs and rain barrels are also very suitable options for low-laying coastal cities as the CMB.

An analysis of the LIDI and GI implementation in 23 U.S. cities indicated that rainwater harvesting for stormwater reuse as an alternative water source can reduce runoff volume up to $20 \%$ [28]. Furthermore, as LIDI and GI were proven to effectively reduce sewer overflows by diverting stormwater from the sewer system, a multidepartment intent encouraging the use of LIDI and GI was initiated in 2007 in order to promote the benefits of using LIDI and GI in protecting drinking water supplies, mitigating sewer overflows, and reducing stormwater pollution [23]. Not only do LIDI and GI surpass gray infrastructure in ecological, social, and political benefits, but they do so also in financial savings. A study done by the U.S. EPA compared LIDI and GI costs with conventional development costs (gray infrastructure) from 17 projects in the U.S. The study showed significant cost savings ranging from 15 to $80-\%$ when using LIDI and GI over conventional development [29] (Table 2-2). 
Table 2-2. Cost Comparison Between LIDI/GI and Gray Infrastructure [29]

\begin{tabular}{|l|l|l|l|}
\hline Project & Conventional Development Cost & LIDI/GI cost & $\begin{array}{l}\text { Percentage } \\
\text { Difference }\end{array}$ \\
\hline $\begin{array}{l}2^{\text {nd }} \text { Avenue SEA Street, Seattle, } \\
\text { WA }\end{array}$ & $\$ 868,803$ & $\$ 651,548$ & $25 \%$ \\
\hline Auburn Hills, WA & $\$ 2,360,385$ & $\$ 1,598,989$ & $32 \%$ \\
\hline Bellingham City Hall, WA & $\$ 27,600$ & $\$ 5,600$ & $80 \%$ \\
\hline $\begin{array}{l}\text { Bellingham Donovan Park, } \\
\text { WA }\end{array}$ & $\$ 52,800$ & $\$ 12,800$ & $76 \%$ \\
\hline Gap Creek, AR & $\$ 4,620,360$ & & \\
\hline Garden Valley, WA & $\$ 324,400$ & $\$ 3,942,100$ & $15 \%$ \\
\hline Laurel Springs, WI & $\$ 1,654,021$ & $\$ 260,700$ & $20 \%$ \\
\hline Mill Creek (per lot), IL & $\$ 12,510$ & $\$ 1,149,552$ & $30 \%$ \\
\hline Prairie Glen, WI & $\$ 1,004,848$ & $\$ 9,100$ & $27 \%$ \\
\hline Somerset, MD & $\$ 2,456,843$ & $\$ 599,536$ & $40 \%$ \\
\hline Tellabs Corporate Campus, IL & $\$ 3,162,160$ & $\$ 1,671,461$ & $32 \%$ \\
\hline
\end{tabular}

\subsection{Low Impact Development and Green Infrastructure Success Stories}

\subsubsection{Sustainable Drainage System in Cambourne Village, England}

Figure 2-2 shows a sustainable drainage system proposal made to Cambourne Village in England. This community was living in a flood hazard area. The project was accepted and implemented in the Lamb Drove area in the village to reduce flooding and control pollution by using variety of LIDI and GI types. The designs implemented in this project included green roofs, permeable road surface and permeable car spaces with storage underneath, swale and underdrain swale, silt basins, detention basins, wetland basins, and shrub and groundcover planting. Figures 2-3 and 2-4 show the impact of implementing LIDI and GI in Lamb Drove on runoff and water quality respectively. 


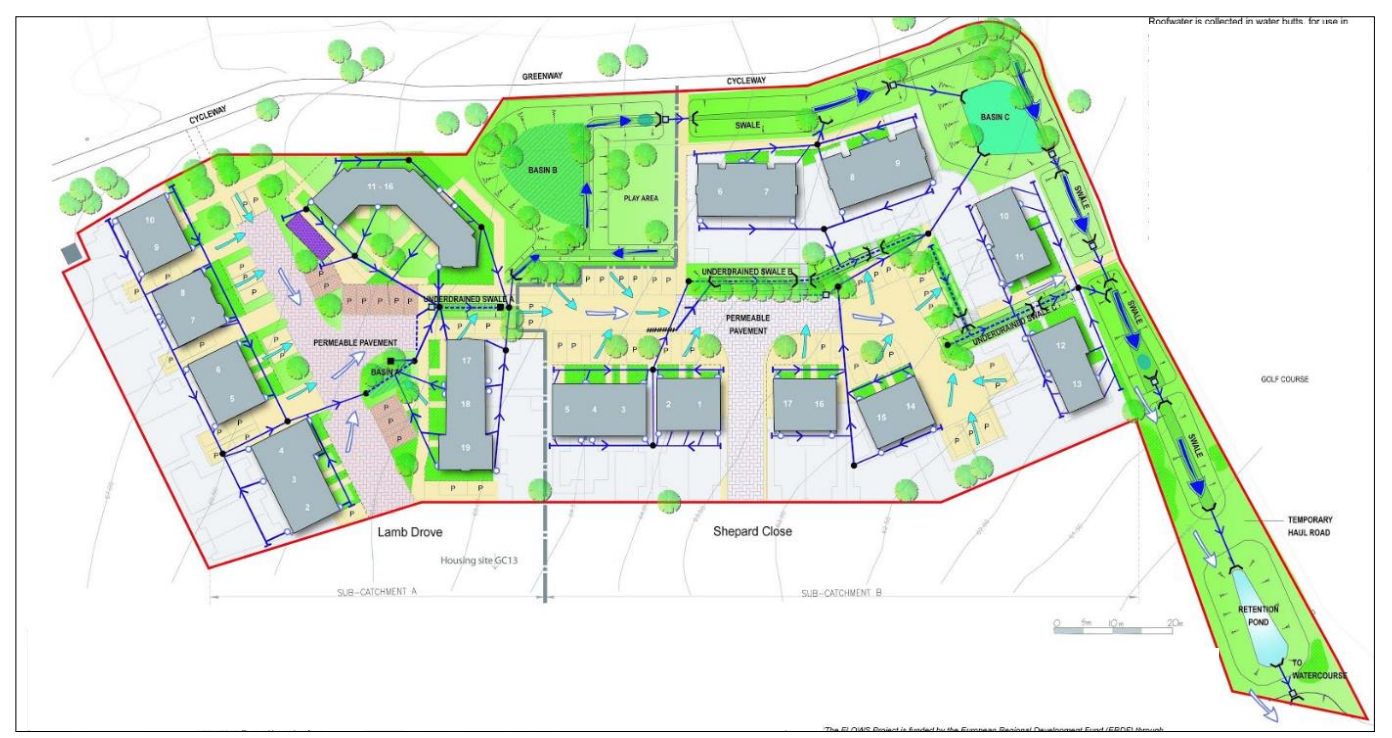

Figure 2-2. Lamb Drove Sustainable Drainage System Proposal [30]

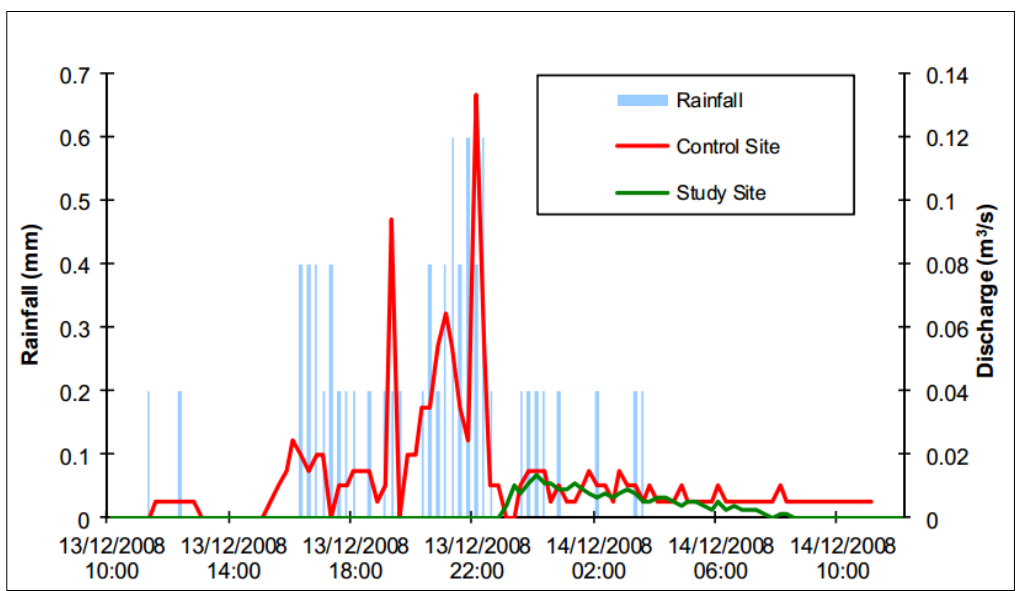

Figure 2-3. Comparison of Water Discharge Pre and Post-development [30]

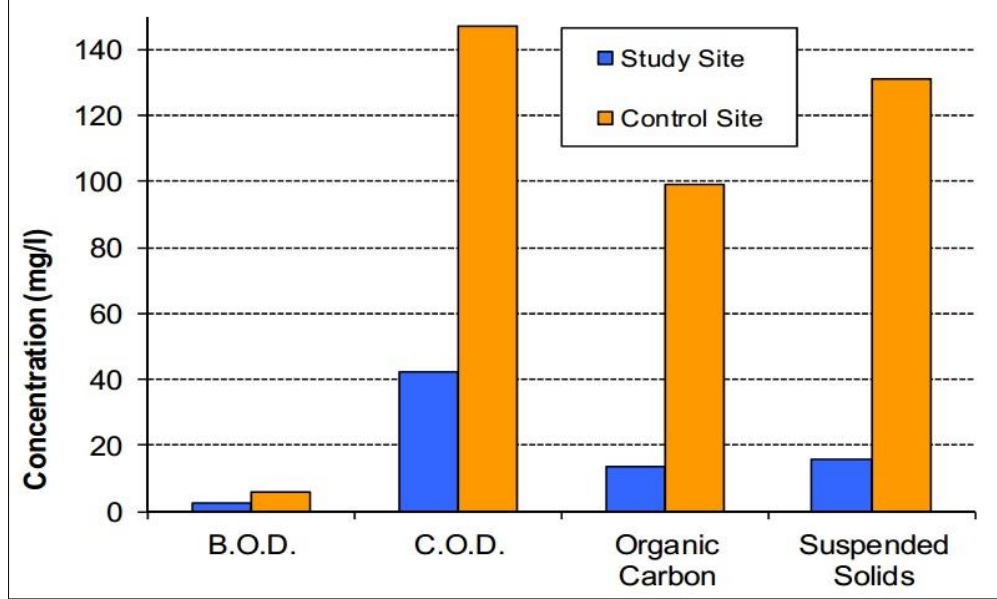

Figure 2-4. Comparison of Water Quality Constituents Pre and Post-development [30] 
Cambridge Shire County Council secured funding for the 3-year monitoring of the system (2008-2011) in order to demonstrate the long-term impact of sustainable drainage system on both the quality and quantity of water leaving the site as well as environmental and social implications. Final results revealed 88\% reduction in discharge, $86 \%$ reduction in TSS, $83 \%$ reduction in organic carbon, $72 \%$ reduction in COD and $61 \%$ reduction in BOD [30].

\subsubsection{Bioswales in Boronda Crossing Shopping Center in Northwestern Salinas, California}

Bioswales are known as vegetated drainage passages with sloped sides designed to trap sediments and treat contaminants [19]. "Research and site-specific evaluations have established that bioswales are effective at slowing and capturing water, settling sediments, and reducing nutrients, metals, and hydrocarbons in the runoff [10]". In this case study, the authors evaluated the effectiveness of bioswales in reducing pesticides toxicity in surface water. Three storms were monitored at three commercial and residential sites, and reduction of contaminants and associated toxicity were quantified. Contaminants were significantly reduced by the bioswales, including $81 \%$ reduction in TSS, $81 \%$ reduction in metals, $82 \%$ reduction in hydrocarbons, and $74 \%$ reduction in pyrethroid pesticides [19].

\subsubsection{Rainwater Harvesting, Bioretention Swales, and Pervious Pavement in Bronx River Watershed in New York City, New York}

In this research, the authors investigated the effectiveness of LIDI and GI to mitigate climate change effects on urban stormwater runoff in the Bronx River Watershed in New York City. The simulations were driven by historical precipitation modified to 
represent future projections using a change factor methodology based on precipitation from the coupled Model Intercomparing Project Phase 5 and projecting climatic conditions 30 years from now [31]. Post-development watershed consisting of rainwater harvesting, porous pavement, and bioretention cells was designed and evaluated using SWMM 5.1. The results showed that, while average increase in historical annual runoff volume under climate change impacts was approximately $48 \%$, the LIDI and GI designs could provide an average reduction of $41 \%$ in annual runoff volume [31].

\subsubsection{Permeable Pavement in St. Louis, Missouri}

In 2008, the City of St. Louis, along with several partners, began a study to investigate the effectiveness of GI in reducing the combined sewer overflow volumes to

the Mississippi River and implemented them when the results showed a reduction. [32]. The study evaluated the effectiveness of permeable pavement in reducing the combined sewer overflow. The comparison between runoff in the reconstruction and postconstruction of the permeable pavement from three alleys showed a $46 \%$ reduction in runoff [32]. Another advantage of implementing permeable pavement is the cost reduction in additional expenditures and land consumption required for conventional collection, conveyance, and detention/retention stormwater infrastructure [33].

\subsubsection{Blue roof and Green Blue Roof in Seoul Metropolitan Area, Korea}

In this case study, the authors evaluated the runoff quantity from blue roof and green blue roof in City Hall Annex Seosomun and the Cheong-un middle school respectively. Blue roof discharge was $0.45 \mathrm{l} / \mathrm{s}$ (at $30 \mathrm{~mm} / \mathrm{h}$ storm event) and a discharge of $1.55 \mathrm{l} / \mathrm{s}$ (at $60 \mathrm{~mm} / \mathrm{h}$ storm event), whereas green blue roof discharge was $0.1 \mathrm{l} / \mathrm{s}$ (at 30 $\mathrm{mm} / \mathrm{h}$ storm event) and a discharge of $0.3 \mathrm{l} / \mathrm{s}$ (at $60 \mathrm{~mm} / \mathrm{h}$ storm event) [31]. The results 
indicated that a green blue roof is more capable of effectively handling long duration rain events than blue roof, however, the blue roof is inexpensive and is still considered a suitable option for retrofitting in urban areas [34].

\subsection{Model Theory and Specifications}

Computer models are powerful tools developed to simulate real-life events and generates results based on simulations to assist engineers, planners, and developers implement their best projects. Through SWMM 5.1, a modeling project can be constructed using six primary environmental components: “(1) external forcing data including precipitation, temperature, and evaporation; (2) a land surface runoff component; (3) a subsurface groundwater component; (4) a conveyance system of pipes, channels, flow regulator, and storage units; (5) contaminant buildup, washoff, and treatment; and (6) LIDI controls [35]". Figure 2-5 shows the process considered in the SWMM 5.1 model.

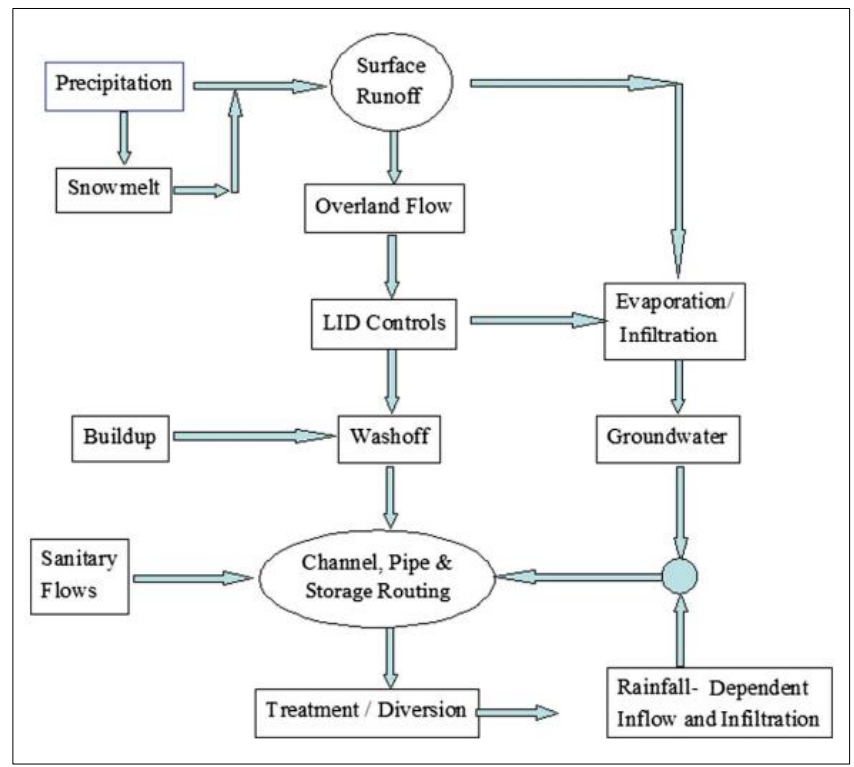

Figure 2-5. Process Considered in the EPA SWMM 5.1 Model [35] 
InfoSWMM offers direct Geographic Information System (GIS) integration through ESRI's ArcGIS, enabling users to work simultaneously on the same integrated platform [36]. What makes this model powerful is its unique ability to interpolate geospatial network through the use of ArcGIS. The main advantage of the integration between ArcGIS and InfoSWMM is the convenience of using GIS databases and shapefile layers to create the exact real-life environment of the study site. For example, instead of manually calculating impervious percentage for each subcatchment or manually inputting Hydrologic Soil Group (HSG) data into the computer software, GIS shapefile layers containing geospatial data are used, resulting in time efficiency and data accuracy.

InfoSWMM SUSTAIN is a very powerful and comprehensive urban stormwater and analysis model integrated within InfoSWMM. It performs very sophisticated hydrologic and water quality modeling in watersheds and urban streams and enables users to develop, evaluate, and select optimal combinations of LIDI and GI [37] to evaluate runoff and pollutant reduction and cost effectiveness of multiple scenarios of LIDI and GI implementation. The LIDI siting manager tool is designed to find the optimum location for more than a dozen of LIDI and GI structures based on ground conditions, such as slope, pervious/impervious, soil type, land use, urban land use, ownership, and groundwater table depths. The theory behind it is that each LIDI and GI type requires unique physical conditions to reach its full potential. In the LIDI optimization tool, users can manually define rules and set targets for runoff and pollutant reduction. The tool then will find the best solution to accommodate those goals. Users 
will also have the opportunity to view performance reports and a cost-effectiveness graph for recommended solutions.

SWMM 5.1 uses the nonlinear reservoir method to model runoff (Figure 2-6).

Runoff is simulated based on data from the subcatchment's area, slope, imperviousness, and rainfall volume or intensity. Based on input data, infiltration and evaporation are calculated and subtracted from the total rainfall volume then surface runoff is generated. Runoff occurs only when the depth of water in the reservoir exceeds the maximum depression storage [38]. Manning's equation is used to calculate surface runoff:

$$
\mathrm{Q}=\left(\frac{1.49}{n}\right) \mathrm{A} R^{\frac{2}{3}} \sqrt{S}
$$

where: $\mathrm{n}=$ Manning's roughness coefficient, $\mathrm{A}=$ flow area, $\mathrm{ft}^{2}, \mathrm{R}=$ hydraulic radius, $\mathrm{ft}$ and $\mathrm{S}=$ slope, $\mathrm{ft} / \mathrm{ft}$.

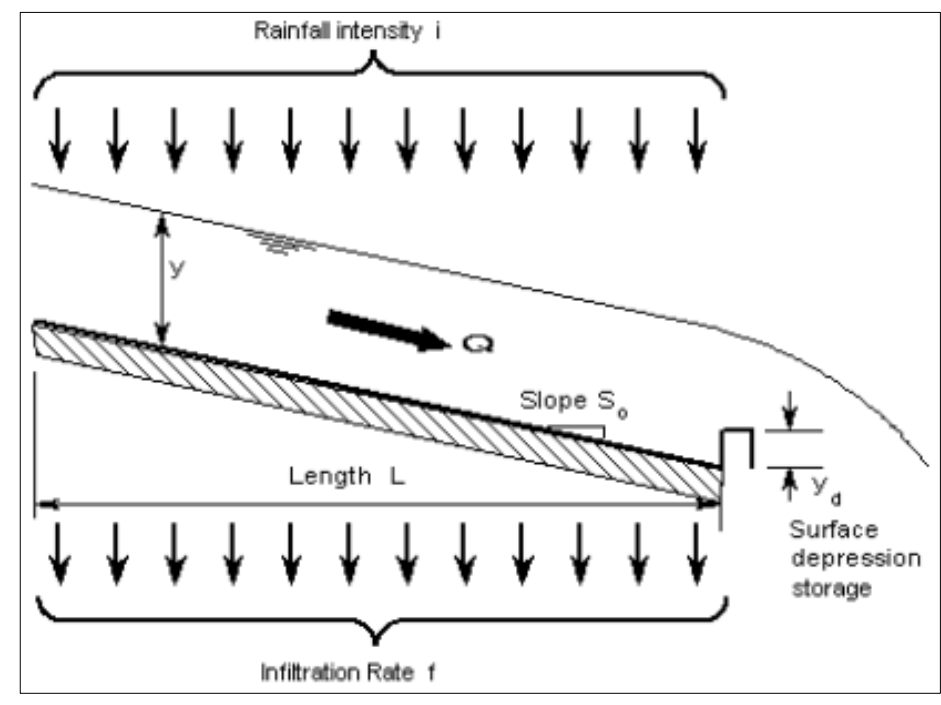

Figure 2-6. EPA SWMM 5.1 Nonlinear Reservoir Method [38]

The nonlinear reservoir method is also implemented in InfoSWMM, with the addition of the National Recovery Conservation Service (NRCS) triangular unit hydrograph method and NRCS dimensionless unit hydrograph method. In both 
InfoSWMM and SWMM 5.1 the user can choose from three routing methods; the steadystate method, the kinematic wave method, and the dynamic wave methods. Three infiltration methods are common between the two models; Horton, Green-Ampt, and NRCS curve number. SWMM 5.1 has the addition of the modified Horton and modified Green-Ampt.

A LIDI feature was added in the SWMM 5.0 whereby different types of LIDI designs can be modeled as a combination of several compartments including surface, soil, storage and underdrain in which the downward infiltration is considered using the GreenAmpt equation and first order decay of water quality constituents can also be modeled [38]. The original form of the Green-Ampt equation is shown below:

$$
f=K_{s}\left(1-M_{d} \psi / F\right)
$$

where: $f=$ infiltration rate, in $/ \mathrm{h}, K_{s}=$ saturated hydraulic conductivity, in $/ \mathrm{h}$, and $M_{d}=$ moisture deficit, fraction, $\psi=$ capillary suction, in, and $\mathrm{F}=$ cumulative infiltration volume, in. The basic assumptions of the Green-Ampt infiltration method are [33]:

1. Homogeneous isotropic soil.

2. Uniformly distributed initial volumetric water content.

3. Well defined wetted front and its uniform propagation.

4. Constant soil suction head at the wetted front.

Both SWMM 5.1 and InfoSWMM can predict runoff quality and buildup and washoff of pollutants. The hydraulic retention time and the first order decay coefficient are used to calculate stormwater effluent concentration based on the runoff influent concentration entering the LIDI [39]. Inputting the pollutant name, concentration in rainfall/groundwater/inflow/dry weather flow, initial concentration throughout the 
conveyance system, and first order decay coefficient will allow the model to compute the effluent concentration stored or retrieved from the LIDI and GI or existing the system through groundwater recharge. The effluent concentration is expressed as the following equation:

$$
C_{f}=C_{\circ} e^{-k t}
$$

where: $C_{f}=$ final concentration, $\mathrm{mg} / \mathrm{l}, C_{\circ}=$ initial concentration, $\mathrm{mg} / \mathrm{l}, \mathrm{k}=$ first order decay coefficient, 1/day, and $\mathrm{t}=$ time, days.

Although InfoSWMM has all the capabilities of SWMM 5.1, the latter was used to model the Indian Creek Drive location to demonstrate the capabilities of a publicly available stormwater management computer model. Table 2-3 compares the two models and highlights their capabilities.

Table 2-3. Comparison of InfoSWMM and SWMM 5.1 Capabilities

\begin{tabular}{|c|c|c|}
\hline & InfoSWMM/SUSTAIN by Innovyze & SWMM5.1 by EPA \\
\hline Runoff simulation & $\begin{array}{l}\text { Provides three equations: } \\
\text { - SWMM Nonlinear Reservoir } \\
\text { - NRCS Triangular Unit } \\
\text { Hydrograph } \\
\text { - NRCS Dimensionless Unit } \\
\text { Hydrograph }\end{array}$ & $\begin{array}{l}\text { Provides one equation: } \\
\text { - SWMM Nonlinear Reservoir }\end{array}$ \\
\hline Infiltration simulation & $\begin{array}{l}\text { Provides three equations: } \\
\text { - Horton } \\
\text { - Green-Ampt } \\
\text { - NRCS Curve Number }\end{array}$ & $\begin{array}{l}\text { Provides five equations: } \\
\text { - Horton and Modified Horton } \\
\text { - Green-Ampt and modified Green- } \\
\text { Ampt } \\
\text { - NRCS Curve Number }\end{array}$ \\
\hline $\begin{array}{l}\text { Water quality buildup and } \\
\text { wash off }\end{array}$ & $\begin{array}{l}\text { Provides } 4 \text { set of buildup equations } \\
\text { and } 3 \text { set of wash off equations }\end{array}$ & $\begin{array}{l}\text { Provides } 4 \text { set of buildup equations } \\
\text { and } 3 \text { set of wash off equations }\end{array}$ \\
\hline LIDI/GI design & Provides 8 LIDI/GI options & Provides 14 LIDI/GI options \\
\hline LIDI suitability analysis & $\begin{array}{l}\text { Performed using InfoSWMM } \\
\text { SUSTAIN Siting Manager Tool }\end{array}$ & $\begin{array}{l}\text { Performed using BMP Siting Tool } \\
\text { (compatible to ArcGIS version } 10.1 \\
\text { or older only) }\end{array}$ \\
\hline Cost analysis & $\begin{array}{l}\text { Performed using SUSTAIN } \\
\text { Optimizer Tool }\end{array}$ & N/A \\
\hline $\begin{array}{l}\text { Design optimizations by } \\
\text { specified targets }\end{array}$ & $\begin{array}{l}\text { Performed using SUSTAIN } \\
\text { Optimizer Tool }\end{array}$ & N/A \\
\hline
\end{tabular}




\section{METHODOLOGY}

To fulfill the first objective of this thesis, which was to establish a comprehensive plan of suitable sites for placing LIDI and GI according to suitability criteria for the CMB, the InfoSWMM SUSTAIN siting manager tool was used. Nine GIS layers were incorporated: shapefiles and rasters of DEM, pervious/impervious percentages, soil type, land use, urban land use, land ownership, groundwater table depth, roads, and streams. The model was then used to predict the most suitable locations for placing different types of LIDI and GI for optimum stormwater runoff and contamination reduction.

To fulfill the second and third objectives of this thesis, which were to test designs of LIDI and GI solutions that will control and reduce flooding as a result of heavy rainfall events and sea-level rise in the CMB and to improve stormwater quality, InfoSWMM SUSTAIN LIDI designer and LIDI optimization tools were used. For the task of modeling the Indian Creek Drive site shown in Figure 1-2, SWMM 5.1 was used. Figure

3-1 describes the workflow process of InfoSWMM to fulfill the first objective (part I) and the second and third objectives (part II). 


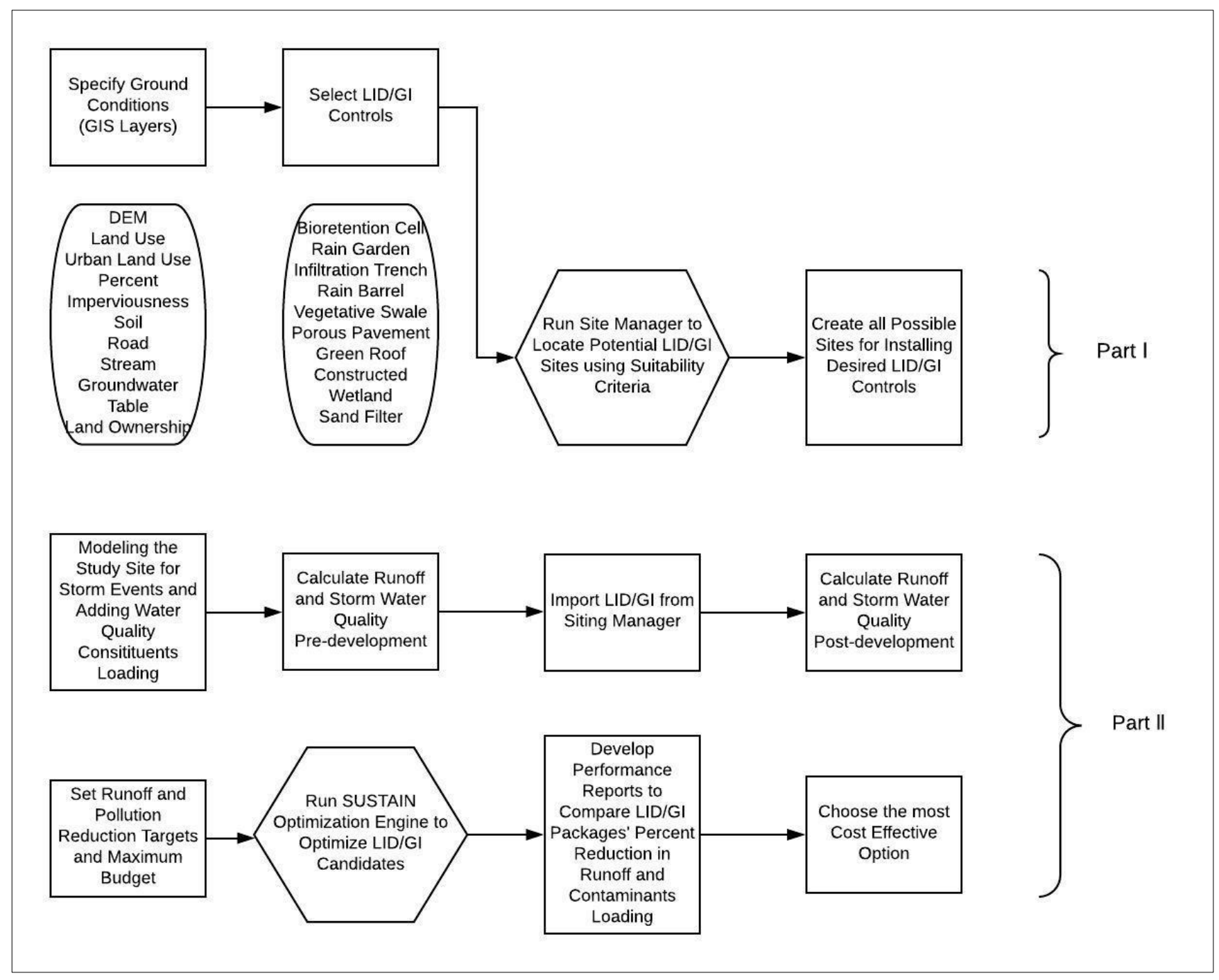

Figure 3-1 Workflow Process of InfoSWMM 


\subsection{Data Sources and Type}

\subsubsection{GIS Data}

All the data used in this research are free and publicly available. Some of the data are downloadable as ready to use in their final format, such as rasters and shapefiles. On the other hand, some are downloadable in their raw formats, such as numbers, tables, and graphs. The raw data had to be converted to shapefiles and rasters for the siting manager to process. Raster data format consists of regular grids to cover space. Each grid cell has a code reflecting the characteristics of a spatial phenomenon (e.g., soil, elevation) at that cell locations [40]. Changes in cell value reflect spatial variation of the phenomenon. Shapefile format is geospatial vector data format that stores shape, location, and attributes of a geographic feature. Table 3-1 shows the GIS data layers that were used in this research along with their format and source.

Table 3-1. GIS Data, Format, and Source

\begin{tabular}{|l|l|l|}
\hline Data & Format & Source \\
\hline DEM & Raster & Miami-Dade County GIS Open Data \\
\hline Land use & Raster & $\begin{array}{l}\text { USGS } \\
\text { National Land Cover Database (NLCD) }\end{array}$ \\
\hline Urban Land use & Shapefile & Free GIS Data by Robin Wilson \\
\hline Percent Imperviousness & Raster & $\begin{array}{l}\text { USGS } \\
\text { National Land Cover Database (NLCD) }\end{array}$ \\
\hline Soil & Shapefile & $\begin{array}{l}\text { USGS } \\
\text { South Florida Information Access (SOFIA) }\end{array}$ \\
\hline Road & Shapefile & Miami-Dade County GIS Open Data \\
\hline Stream & Shapefile & Miami-Dade County GIS Open Data \\
\hline Groundwater Table & Raw data (figure & $\begin{array}{l}\text { USGS } \\
\text { National Water Information System }\end{array}$ \\
\hline Land Ownership & format) & Miami-Dade County GIS Open Data \\
\hline
\end{tabular}


According to the EPA, the nine GIS data layers listed in Table 3-1 are utilized as follows [41] :

1. The DEM is used to calculate the drainage slope and drainage areas that are used to identify the suitable locations of LIDI and GI.

2. The land use is used to eliminate the unsuitable locations for LIDI and GI.

3. The urban land use data contain the boundaries for the buildings and the impervious areas needed to identify suitable locations for LIDI and GI.

4. The impervious grid is used to identify the suitable location for LIDI and GI for the given suitability criteria.

5. The soil data contain the soil properties such as HSG, which are used to identify suitable locations for LIDI and GI.

6. The road layer is used to identify suitable locations for some LIDI and GI that must be placed within a specific road buffer area.

7. The stream layer is used to define a buffer so that certain LIDI and GI types can be placed outside the buffer to minimize the impact on the streams.

8. The groundwater table depth layer is used to identify suitable locations for the infiltration of LIDI and GI.

9. A land ownership layer is used to identify the locations on the public and private land.

\subsubsection{Meteorological Data}

The only meteorological data needed in this research are average temperature and evaporation data for Miami-Dade County, which were retrieved from the Quantification of Hydrological Processes and Assessment of Rainfall-Runoff Models in Miami-Dade 
County report prepared by the USGS in cooperation with the SFWMD [42], and the 5, 10, and 100-year 24-hour storm events intensities. The storm events intensities were calculated using the NRCS method and Miami-Dade County Intensity-DurationFrequency (IDF) curves. According to Miami-Dade County IDF curves, the 5, 10, and 100-year 24-hour storm events yield a cumulative depth of 7.44 inches, 8.64 inches, and 13.44 inches respectively. Tables 3-2, 3-3, and 3-4 shows the calculated cumulative depths and intensities of the storm events, and Figures 3-2, 3-3, and 3-4 shows the design unit hyetograph of each event. 
Table 3-2. Calculated 5-year, 24-hour Storm Event Cumulative Depths and Average Intensities (using the NRCS method, and IDF curve retrieved from [43])

\begin{tabular}{|c|c|c|c|}
\hline Time (hr) & Total Depth (\%) & Cumulative Depth (in) & Average Intensity (in/hr) \\
\hline 0 & 0 & 0 & 0 \\
\hline 1 & 1 & 0.07 & 0.07 \\
\hline 2 & 2.2 & 0.16 & 0.09 \\
\hline 3 & 3.55 & 0.26 & 0.10 \\
\hline 4 & 4.91 & 0.37 & 0.10 \\
\hline 5 & 6.2 & 0.46 & 0.10 \\
\hline 6 & 8.1 & 0.60 & 0.14 \\
\hline 7 & 10 & 0.74 & 0.14 \\
\hline 8 & 12.1 & 0.90 & 0.16 \\
\hline 9 & 14.7 & 1.09 & 0.19 \\
\hline 10 & 18.6 & 1.38 & 0.29 \\
\hline 11 & 23.5 & 1.75 & 0.36 \\
\hline 12 & 66 & 4.91 & 3.16 \\
\hline 13 & 77.4 & 5.76 & 0.85 \\
\hline 14 & 82.1 & 6.11 & 0.35 \\
\hline 15 & 85.3 & 6.35 & 0.24 \\
\hline 16 & 88.1 & 6.55 & 0.21 \\
\hline 17 & 90.1 & 6.70 & 0.15 \\
\hline 18 & 92.2 & 6.86 & 0.16 \\
\hline 19 & 93.5 & 6.96 & 0.10 \\
\hline 20 & 94.8 & 7.05 & 0.10 \\
\hline 21 & 96.1 & 7.15 & 0.10 \\
\hline 22 & 97.4 & 7.25 & 0.10 \\
\hline 23 & 98.7 & 7.34 & 0.10 \\
\hline 24 & 100 & 7.44 & 0.10 \\
\hline
\end{tabular}

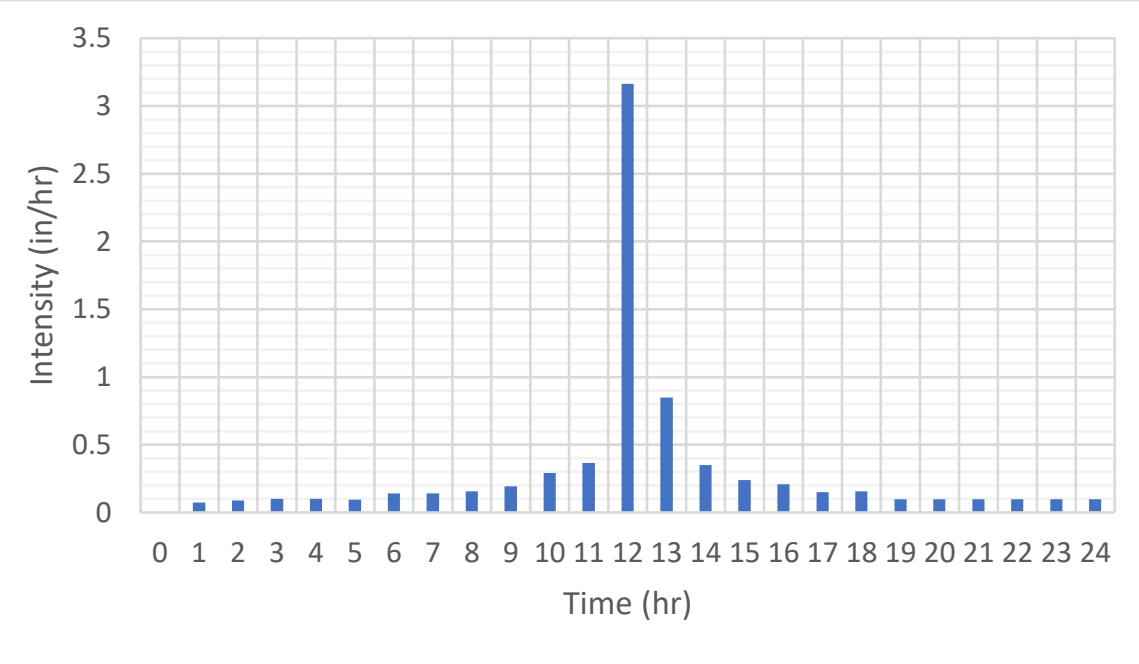

Figure 3-2. 5-year, 24-hour Design Storm Hyetograph 
Table 3-3. Calculated 10-year, 24-hour Storm Event Cumulative Depths and Average Intensities (using the NRCS method, and IDF curve retrieved from [43])

\begin{tabular}{|c|c|c|c|}
\hline Time (hr) & Total Depth (\%) & Cumulative Depth (in) & Average Intensity (in/hr) \\
\hline 0 & 0 & 0.00 & 0.00 \\
\hline 1 & 1 & 0.09 & 0.09 \\
\hline 2 & 2.2 & 0.19 & 0.10 \\
\hline 3 & 3.55 & 0.31 & 0.12 \\
\hline 4 & 4.91 & 0.42 & 0.12 \\
\hline 5 & 6.2 & 0.54 & 0.11 \\
\hline 6 & 8.1 & 0.70 & 0.16 \\
\hline 7 & 10 & 0.86 & 0.16 \\
\hline 8 & 12.1 & 1.05 & 0.18 \\
\hline 9 & 14.7 & 1.27 & 0.22 \\
\hline 10 & 18.6 & 1.61 & 0.34 \\
\hline 11 & 23.5 & 2.03 & 0.42 \\
\hline 12 & 66 & 5.70 & 3.67 \\
\hline 13 & 77.4 & 6.69 & 0.98 \\
\hline 14 & 82.1 & 7.09 & 0.41 \\
\hline 15 & 85.3 & 7.37 & 0.28 \\
\hline 16 & 88.1 & 7.61 & 0.24 \\
\hline 17 & 90.1 & 7.78 & 0.17 \\
\hline 18 & 92.2 & 7.97 & 0.18 \\
\hline 19 & 93.5 & 8.08 & 0.11 \\
\hline 20 & 94.8 & 8.19 & 0.11 \\
\hline 21 & 96.1 & 8.30 & 0.11 \\
\hline 22 & 97.4 & 8.42 & 0.11 \\
\hline 23 & 98.7 & 8.53 & 0.11 \\
\hline 24 & 100 & 8.64 & 0.11 \\
\hline
\end{tabular}

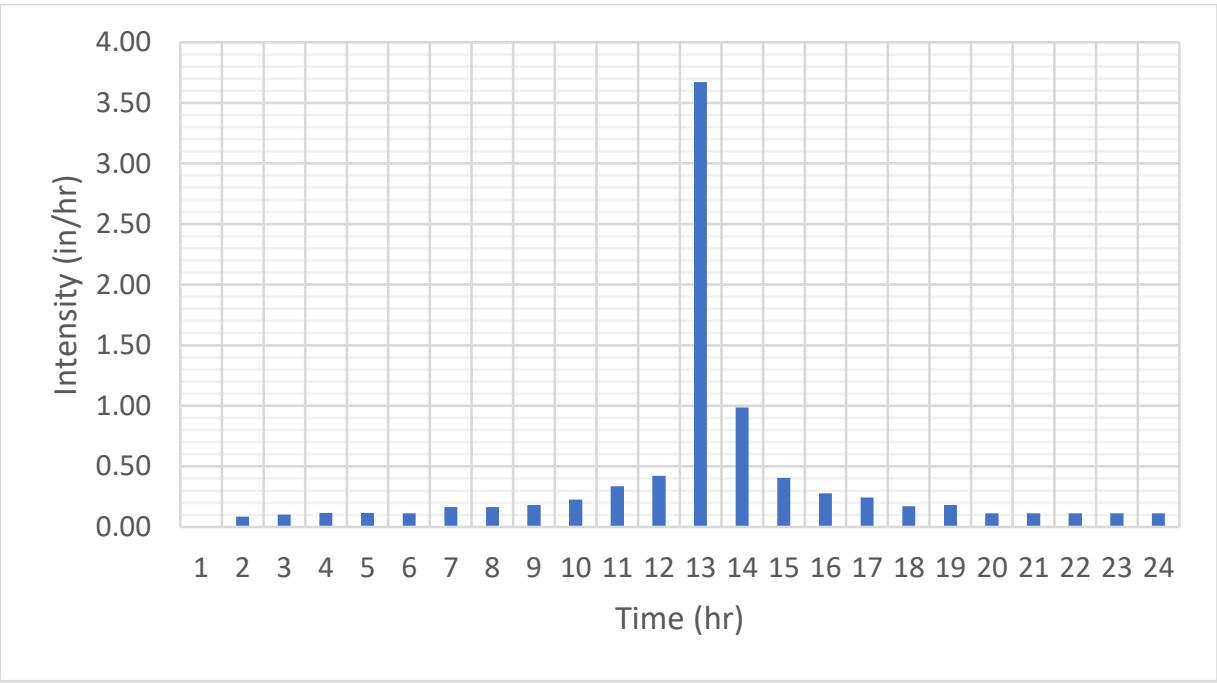

Figure 3-3. 10-year, 24-hour Design Storm Hyetograph 
Table 3-4. Calculated 100-year, 24-hour Storm Event Cumulative Depths and Average Intensities (using the NRCS method, and IDF curve retrieved from [43])

\begin{tabular}{|c|c|c|c|}
\hline Time (hr) & Total Depth (\%) & Cumulative Depth (in) & Average Intensity (in/hr) \\
\hline 0 & 0 & 0.00 & 0.00 \\
\hline 1 & 1 & 0.13 & 0.09 \\
\hline 2 & 2.2 & 0.30 & 0.16 \\
\hline 3 & 3.55 & 0.48 & 0.18 \\
\hline 4 & 4.91 & 0.66 & 0.18 \\
\hline 5 & 6.2 & 0.83 & 0.17 \\
\hline 6 & 8.1 & 1.09 & 0.26 \\
\hline 7 & 10 & 1.34 & 0.26 \\
\hline 8 & 12.1 & 1.63 & 0.28 \\
\hline 9 & 14.7 & 1.98 & 0.35 \\
\hline 10 & 18.6 & 2.50 & 0.52 \\
\hline 11 & 23.5 & 3.16 & 0.66 \\
\hline 12 & 66 & 8.87 & 5.71 \\
\hline 13 & 77.4 & 10.40 & 1.53 \\
\hline 14 & 82.1 & 11.03 & 0.63 \\
\hline 15 & 85.3 & 11.46 & 0.43 \\
\hline 16 & 88.1 & 11.84 & 0.38 \\
\hline 17 & 90.1 & 12.11 & 0.27 \\
\hline 18 & 92.2 & 12.39 & 0.28 \\
\hline 19 & 93.5 & 12.57 & 0.17 \\
\hline 20 & 94.8 & 12.74 & 0.17 \\
\hline 21 & 96.1 & 12.92 & 0.17 \\
\hline 22 & 97.4 & 13.09 & 0.17 \\
\hline 23 & 98.7 & 13.27 & 0.17 \\
\hline 24 & 100 & 13.44 & 0.17 \\
\hline
\end{tabular}

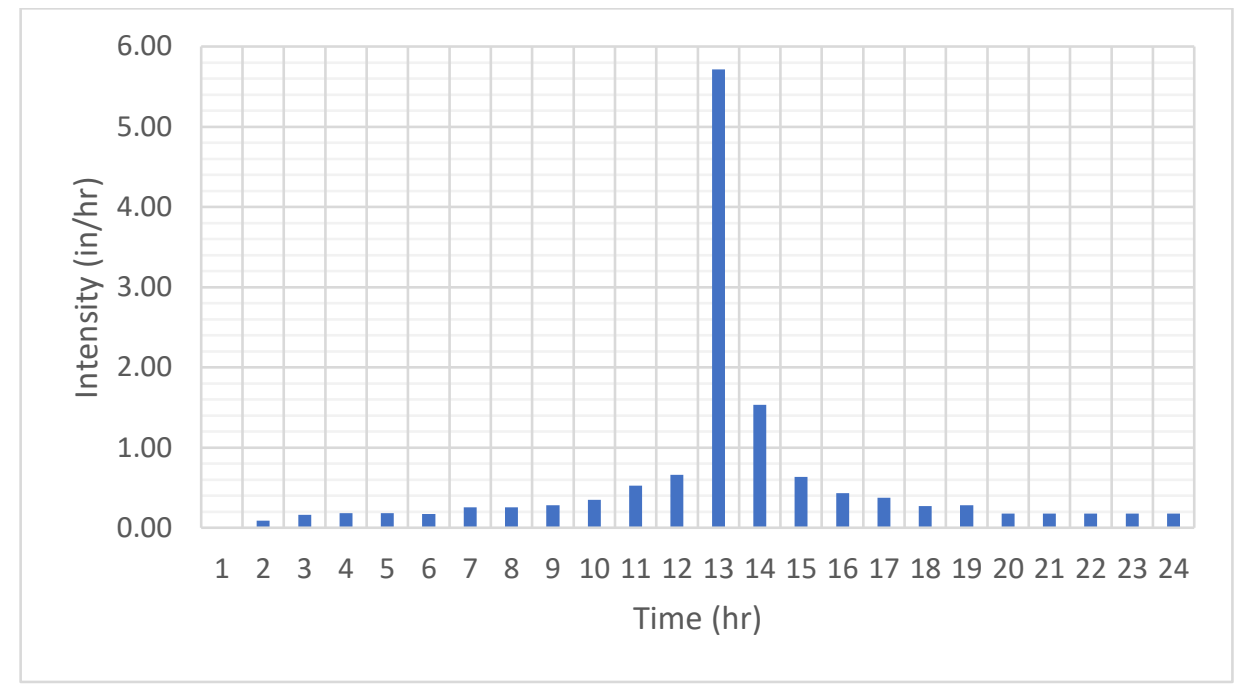

Figure 3-4. 100-year, 24-hour Design Storm Hyetograph 


\subsection{Modeling Part I}

The first part of the modeling resulted in fulfilling the first objective of this thesis, which was to establish a comprehensive plan of suitable sites for placing LIDI and GI according to suitability criteria for the CMB. Thorough and comprehensive analysis on placement criteria was done to ensure getting the maximum benefit of the implemented designs. The first step was to divide the CMB into neighborhoods as shown in Figure 3-5.

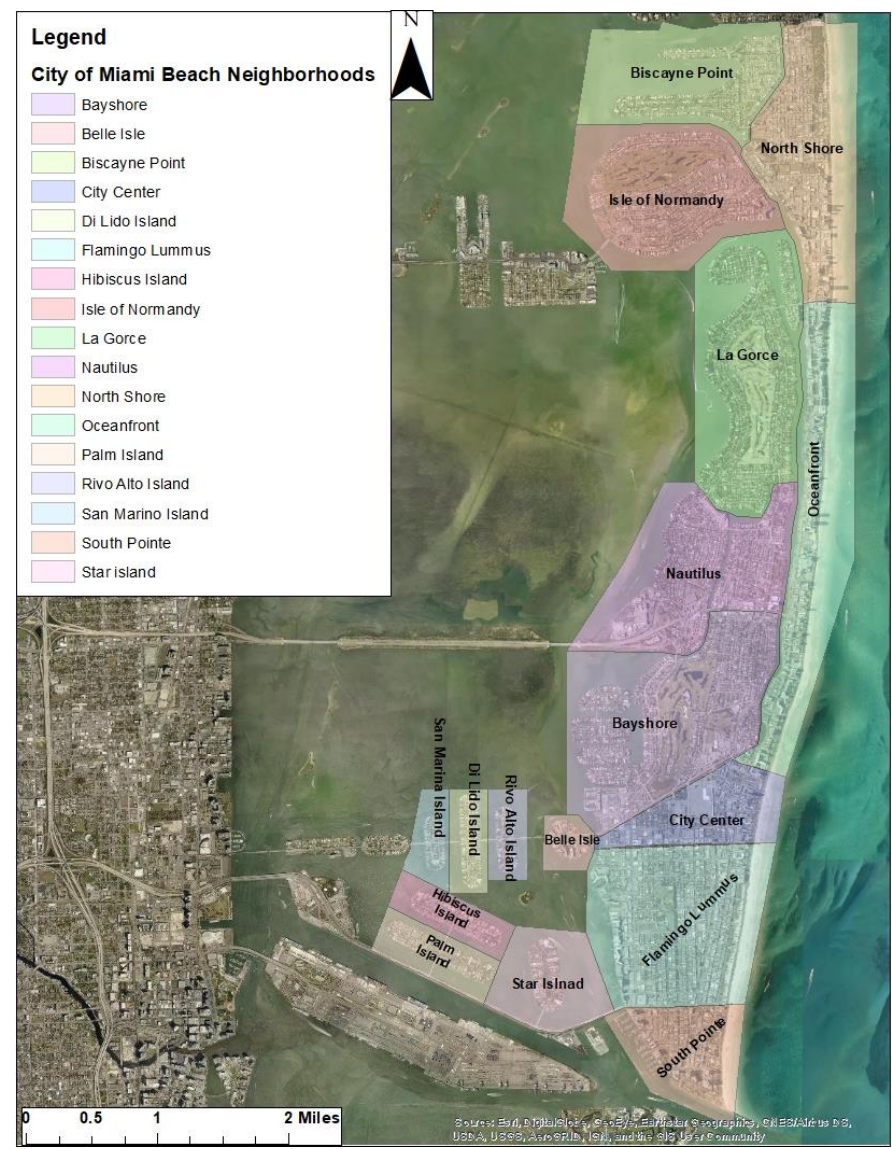

Figure 3-5. City of Miami Beach Neighborhoods Map (Background Map [6] Neighborhoods Data [44])

For diversity purposes, neighborhoods with the most diverse land uses were chosen, such as Bayshore and Flamingo Lummus. In addition, neighborhoods that are considered hotspots for tourism were also targeted, such as City Center, and South Pointe 
because the addition of recreational and aesthetically pleasing areas can be beneficial. Neighborhoods consisting of mainly residential single dwelling land use were excluded as LIDI and GI designs for residential areas are minimal. However, a part of the North Shore neighborhood was modeled because it is the neighborhood where the city is considering preparing a master plan for a particular area within the neighborhood. Stormwater runoff quantity and quality were simulated for the pre and post-development scenarios in North Shore neighborhood study site, and LIDI and GI designs were optimized in part two of modeling.

\subsubsection{Ground Characteristics}

Nine GIS layers had to be geo-processed to fit the boundaries of the CMB. All the GIS layers had to be clipped with the addition of dissolving the land use, urban land use, and land ownership layers for the model to run and process efficiently. Attribute tables of the nine GIS layers are shown in the Appendices. Figure 3-6 shows the siting manager operation window where the nine GIS layers are specified. The GIS layers were further

analyzed by the siting manager as shown in Figure 3-7; the land use code field (A), urban land use type field (B), soil code field (C), and land ownership field (D) are lookup tables in which each cell or polygon is defined for LIDI and GI suitability, surface type, HSG, and ownership type respectively. 


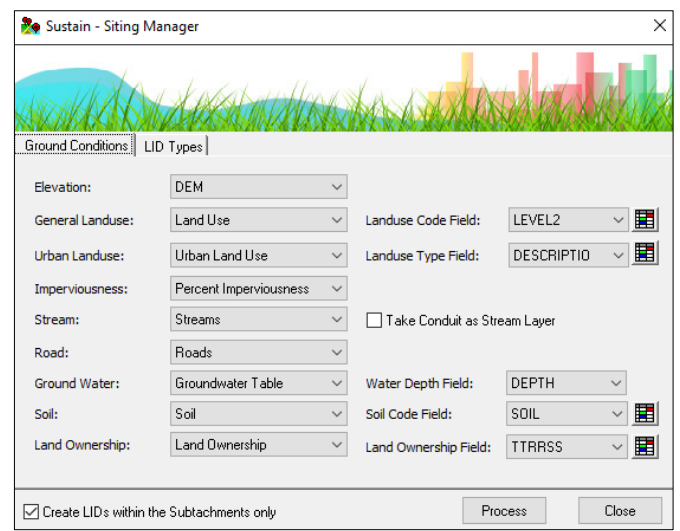

Figure 3-6. Specifying Ground Conditions in the Siting Manager
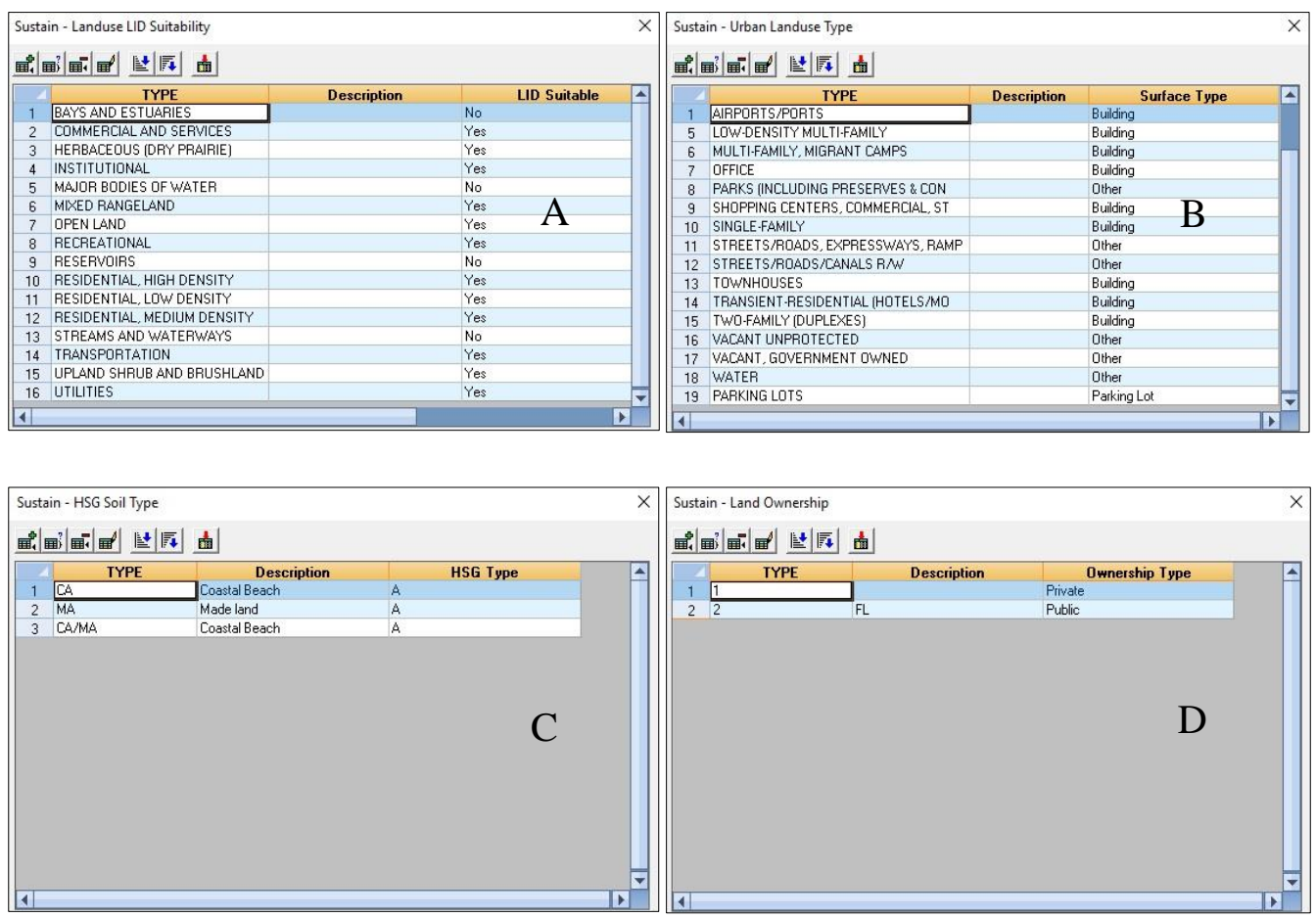

Figure 3-7. (A) Land Use Code Field (B) Urban Land Use Type Field (C) Soil Code Field (D) Land Ownership Field

This was the first set of rules that defined LIDI and GI placement criteria. For example, as shown in Figure 3-7 (A), bays and estuaries, major bodies of water, reservoirs, and streams and waterways were set as not suitable for LIDI placement, whereas the rest of land uses were suitable for LIDI placement. By processing that set of rules, the model will avoid placing LIDI and GI at unsuitable locations. In addition, as 
shown in Figure 3-7 (B), the set of rules for the urban land use layer was applied for surface type. Each urban land use category has to be specified whether it is a building, parking lot, or other type of use. That is done to ensure a green roof is placed on the rooftop of a building, or a porous pavement is placed on parking lots and not vice versa.

\subsubsection{Low Impact Development and Green Infrastructure Siting Criteria}

Each LIDI and GI requires certain ground conditions for it to work efficiently. This part of the modeling setup was responsible for defining siting criteria rules for each LIDI and GI. The set of rules for ground conditions include drainage area, soil type, slope percentage, imperviousness percentage, groundwater depth, road buffer, stream buffer, building buffer, and land ownership. The criteria used in this case study are based on the U.S. EPA recommendations published in their Stormwater Best Management Practice Design Guide Volume I and The Use of BMPs in Urban Watersheds reports. The recommended criteria were gathered from both reports and are summarized in Table 3-5. Figure 3-8 shows the chosen siting criteria for green roof (A), bioretention cell (B), porous pavement $(C)$, grassed swale $(D)$, infiltration trench $(E)$, sand filter $(F)$, constructed wetland $(\mathrm{G})$, and rain barrel $(\mathrm{H})$.

Land ownership siting criteria was ignored for all LIDI and GI as it is mainly beneficial for decision makers and city planners and was not directly related to the purpose of this study, which is to investigate the optimum locations for LIDI and GI placement geologically and to study their effectiveness in stormwater runoff and contamination reduction. The imperviousness percentages in the siting criteria for all LIDI and GI were chosen based on the runoff curve number $(\mathrm{CN})$ because, " $\mathrm{CN}$ is based on soils, plant cover, amount of impervious areas, interception, and surface storage [45]". 
Therefore, it was the best representative number of the ground condition desired for each LIDI and GI type. The imperviousness percentage of $</=68$ was used for bioretention cell, grassed swale, infiltration trench, sand filter, and constructed wetland. The $\mathrm{CN}$ value of 68 represents open spaces with grass cover $<50 \%$. By setting the imperviousness percentage to $</=68$, the model is programmed to avoid recommending LIDI and GI placement at impermeable or semi impermeable areas, where there would be a need for full excavation of the parent ground material. Imperviousness percentage of $>/=76$ was used for porous pavement. The $\mathrm{CN}$ value of 76 represents impervious areas of gravel material. The model then was programmed to search for the most suitable porous pavement locations at areas consisting of at least gravel texture or a texture of higher impermeability such as pavement and asphalt. This $\mathrm{CN}$ value was used to avoid placing porous pavement on permeable soils. 
Table 3-5. Recommended Ground Conditions for LIDI and GI Placement [46] [47]

\begin{tabular}{|l|c|c|c|c|c|c|c|c|}
\hline LIDI/GI Type & $\begin{array}{c}\text { Drainage } \\
\text { Area } \\
(\mathrm{ac})\end{array}$ & $\begin{array}{c}\text { Slope } \\
(\%)\end{array}$ & $\begin{array}{c}\text { Imperviousness } \\
(\%)\end{array}$ & HSG & $\begin{array}{c}\text { GW } \\
\text { Depth } \\
(\mathrm{ft})\end{array}$ & $\begin{array}{c}\text { Road } \\
\text { Buffer } \\
(\mathrm{ft})\end{array}$ & $\begin{array}{c}\text { Stream } \\
\text { Buffer } \\
(\mathrm{ft})\end{array}$ & $\begin{array}{c}\text { Building } \\
\text { Buffer } \\
(\mathrm{ft})\end{array}$ \\
\hline $\begin{array}{l}\text { Bioretention } \\
\text { Cell }\end{array}$ & $<2$ & $<5 \%$ & $>0 \%$ & A-D & $>2$ & $<100$ & $>100$ & -- \\
\hline $\begin{array}{l}\text { Constructed } \\
\text { Wetland }\end{array}$ & $>25$ & $<15 \%$ & $>0 \%$ & A-D & $>4$ & -- & $>100$ & -- \\
\hline $\begin{array}{l}\text { Grassed } \\
\text { Swale }\end{array}$ & $<5$ & $<4 \%$ & $>0 \%$ & A-D & $>2$ & $<100$ & -- & -- \\
\hline $\begin{array}{l}\text { Green Roof } \\
\text { Infiltration } \\
\text { Trench }\end{array}$ & -5 & $<15 \%$ & $>0 \%$ & A-B & $>4$ & -- & -- & -- \\
\hline $\begin{array}{l}\text { Porous } \\
\text { Pavement }\end{array}$ & $<5$ & $<5 \%$ & $>0 \%$ & A-B & $>2$ & -- & -- & -- \\
\hline Rain Barrel & -- & -- & -- & -- & -- & -- & - & $<30$ \\
\hline $\begin{array}{l}\text { Sand Filter } \\
\text { surface) }\end{array}$ & $<10$ & $<10 \%$ & $>0 \%$ & A-D & $>2$ & -- & $>100$ & -- \\
\hline
\end{tabular}



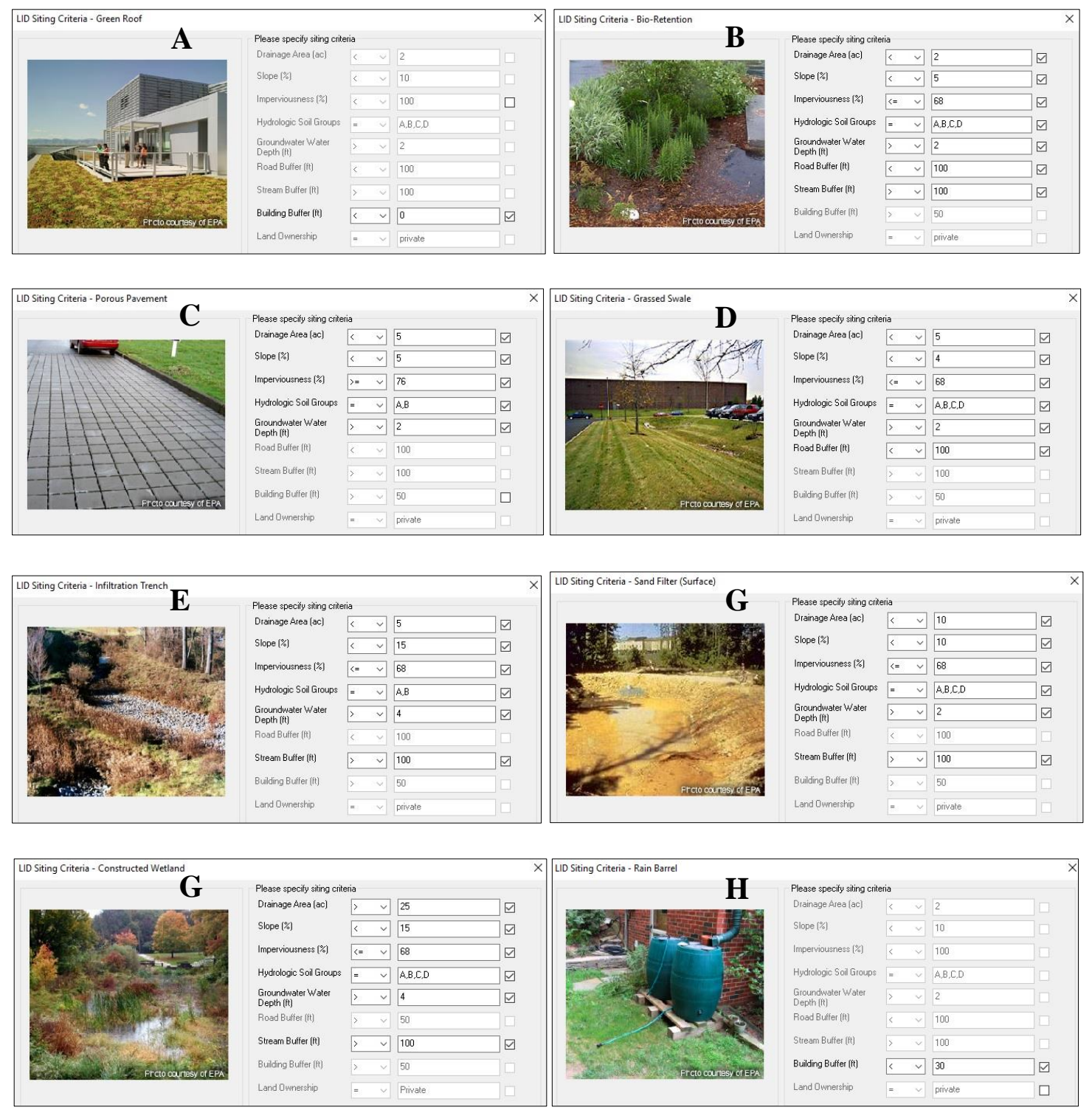

Figure 3-8. LIDI and GI Siting Criteria for (A) Green Roof (B) Bioretention Cell (C) Porous Pavement (D) Grassed Swale (E) Infiltration Trench (F) Sand Filter (G) Constructed Wetland (H) Rain Barrel

\subsection{Modelling Part II}

Part II of modeling resulted in fulfilling the second and third objectives of this thesis, which were to test designs of LIDI and GI solutions that will control and reduce flooding as a result of heavy rainfall events and sea-level rise in the CMB and to improve stormwater quality. Part II of the modeling setup consisted of modeling the study site for 
storm events and adding water quality constituents' loadings and concentrations to calculate runoff and stomrwater quality (pre-development), then rerunning the model with the added LIDI and GI that resulted from part I of modeling (post-development) and compare the results of the two scenarios for stormwater runoff and water quality.

\subsubsection{North Shore Study Site Subcatchment Characteristics and Simulation Options}

The study site is located in North Shore neighborhood in the CMB covering an area of 95 acres from $81^{\text {st }}$ street to $75^{\text {th }}$ street (Figure 1-3). The subcatchment is $93.6 \%$ impervious, and the DEM GIS layer was used for slope calculations automatically. Manning's $\mathrm{n}$ for impervious portion of the subcatchment was set to 0.016 and 0.15 for the pervious portion. Depression storage was accounted for at 0.05 inches for both the impervious and pervious portions of the subcatchment. The depression storage is the storage in which water accumulates and paddles on before it exceeds it and gets converted into runoff. When calculating runoff, depression storage is the only depth subtracted from a rainfall event cumulative depth on impervious surfaces. Green Ampt equation was used as the infiltration model and EPA SWMM non-linear reservoir method was used as the runoff model. The subcatchment was linked to a rain gage, which was linked to three time series tables $(5,10$, and 100-year, 24-hour storm events) that can be selected interchangeably. Rain gage data format was set to cumulative with 1:00 hour time interval. The subcatchment was also linked to an outfall, which was the runoff routing destination. Climatology settings of the modeling simulation included the addition of average temperature of $75.3 \mathrm{~F}^{\circ}$ and evaporation rate of $0.2 \mathrm{in} / \mathrm{h}$ for the month of April. 


\subsubsection{Soil Characteristics and Green-Ampt Infiltration Parameters}

The CMB HSG is classified as type A soil, consisting mainly of sands or gravelly sands. Type A soil is known for its high infiltration rate and low runoff potential, which makes it ideal for designing BMP, as the native soil can be used for all LIDI and GI. Green-Ampt infiltration parameters that had to be defined were suction head, soil saturated hydraulic conductivity, and initial deficit. Those parameters for a sandy textured soil are 1.93 inches, $4.74 \mathrm{in} / \mathrm{h}$, and 0.375 .

\subsubsection{Water Quality Simulation}

To simulate water quality, a land use with street cleaning, buildup, and washoff qualities had to be defined. Since North Shore neighborhood is classified as low-density residential, typical pollutant loadings were retrieved from Table 2-1 for the specific land use. The model can only simulate water quality constituents with maximum loadings of $0.001 \mathrm{lb} / \mathrm{acre}$ or higher. Given the subcatchment size and the relatively small pollutant loadings for a low-density residential land use, the model can only simulate water quality for TSS, BOD, and COD. Using the subcatchment specifications with the guidance of Table 2-1 for typical loading values for low-density residential land use, TSS, BOD and COD loadings were calculated to be $0.17 \mathrm{lb} / \mathrm{acre}, 0.002 \mathrm{lb} / \mathrm{acre}$, and $0.019 \mathrm{lb} / \mathrm{acre}$ respectively. Street cleaning parameters were set to zero to avoid interfering with LIDI and GI removal efficiencies. The exponential function used to simulate pollutant buildup (B) was:

$$
B=C_{1}\left(1-\exp \left(-C_{3} t\right)\right)
$$

where: $\mathrm{B}=$ buildup, mass/area (normalizer: area), $C_{1}=$ maximum buildup, mass/area, and $C_{3}=$ rate constant, $1 /$ time 
The storm-event mean concentration (EMC) function was used to simulate pollutant washoff (W):

$$
W=C_{1} Q
$$

where: $C_{1}=$ concentration, mass/volume, and $Q=$ surface runoff, volume/time (the conversion between user-defined flow units used for runoff and volume is handled internally by SWMM [48]).

At this stage of modeling setup, the model was completed and ready to process the predevelopment scenario.

\subsubsection{Low Impact Development and Green Infrastructure Design Parameters and}

\section{Considerations}

After running the model for the pre-development scenario, results from the siting manager for North Shore study site were added to the InfoSWMM Browser to rerun the model for post-development scenario. Multiple national and international governmental, non-governmental organizations, and universities have created design manuals of all kinds for the design of LIDI and GI. Such national organizations include the U.S. EPA, Denver Urban Drainage and Flood Control District, Philadelphia Water Department, NY State Department of Environmental Conservation, and University of New Hampshire Stormwater Center. The physical design parameters and layers thickness used in this research were chosen with a consideration of the unique geological features of the CMB. In addition, they were designed to provide enough storage to accommodate runoff to prevent the LIDI and GI from flooding yet avoiding overdesigning the units, which would provide unnecessary storage and increase capital cost tremendously. However, all the chosen design parameters did not exceed or drop below the recommended range 
stated in the design manuals listed above to ensure the effectiveness of the designs. The soil type chosen for the LIDI and GI designs was soil type A because it is the native soil of the CMB and one of the recommended soil types by the U.S. EPA for all LIDI and GI types. Conductivity slope is calculated using the following equation:

Conductivity slope $=0.48 \times(\%$ sand $)+0.85 \times(\%$ clay $)$

Void ratio is calculated using the following equation:

$$
\text { Void ratio }=\frac{\text { porosity }}{1-\text { porosity }}
$$

LIDI and GI engineered design layers are specified in Table 3-6.

\subsubsection{Bioretention Cell Proposed Solution}

Bioretention cell, also known as raingarden, consists of two major layers; soil and storage. The soil layer includes surface layer and filter media. The bioretention cell design should also include berm to create an additional ponding area and to provide temporary storage in the case of extreme runoff conditions. There are typically two scales of bioretention cells; level one and level two. The difference between them is that level two bioretention cell is designed with thicker filter media and an extra storage layer of gravel sump. The larger capacity design allows the cell to attenuate more runoff. Therefore, to select which of the two scales is to be implemented, complete hydrological modeling accounting for the entire water budget should be performed to make the right decision. This is also the process that should be followed when designing any other kind of LIDI or GI to ensure the effectiveness of the design and, prevent it from flooding, and avoid overdesigning. Figures of both bioretention cell scales are shown in Appendix C. 
The proposed bioretention cell solution prepared for the CMB have the following specifications; 4 inches berm height, 12 inches perennial plant cover, 2 inches mulch surface layer, 22 inches loamy sand filter media, and 6 inches PEA gravel storage layer. Mulch is the commonly used surface cover as it is known to enhance plant survival and due to its effectiveness of pre-treating runoff. Perennials were chosen because, "They are preferably shallow-rooting, self-generating plants that spread rapidly and require minimal nutrients [49]". The filter media layer below the surface layer is recommended to be composed of 85 to $88 \%$ sand, 8 to $12 \%$ soil fines, and 3 to $5 \%$ organic matter [49]. Therefore, a loamy sand soil layer was modeled and proposed. The storage layer is made of PEA gravel, which is known to have significance conveyance rate and drainage features. This layer holds the filtered water providing extra capacity for the filter media to absorb water, which prevents/delays fully saturation state in the soil. The water then infiltrates the parent soil facilitating groundwater recharge. A perforated underdrain pipe could be installed at the top of the storage layer if desired for water recycling purposes.

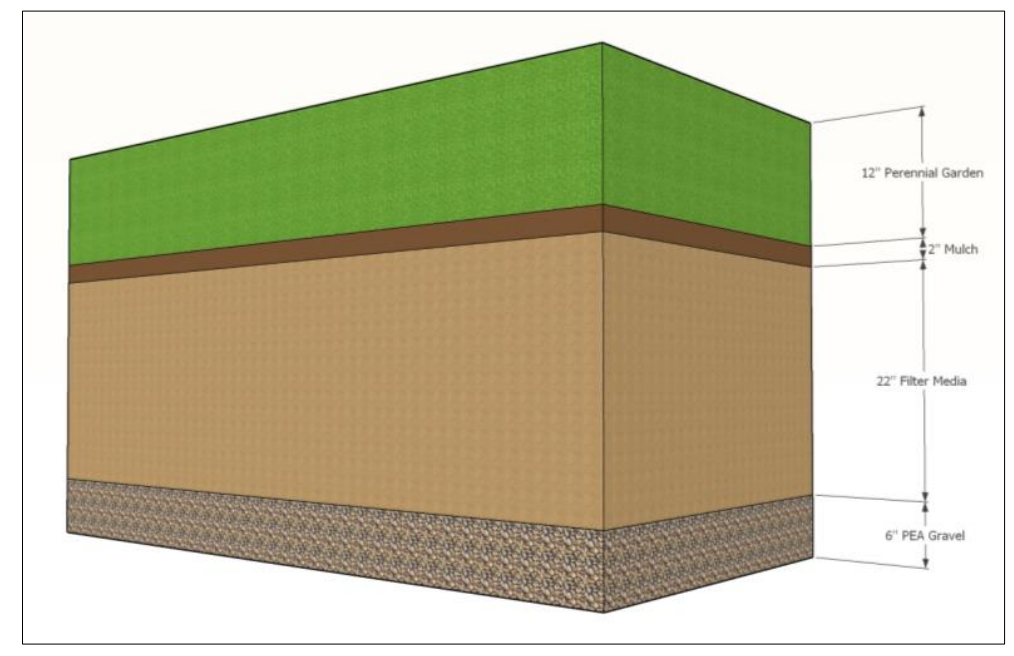

Figure 3-9. Bioretention Cell Proposed Solution 


\subsubsection{Green Roof Proposed Solution}

A green roof is an engineered vegetative layer that converts impervious rooftop surfaces to previous ones resulting in reducing runoff, improving stormwater quality, mitigating the UHI effects, and reducing air pollution and GHG emissions. Similar to the bioretention cell, there are two scales of green roof; extensive and intensive. However, they both consist of the same layers. A green roof typically consists of engineered vegetative and soil layers, filtration membrane, drainage mat, thermal insulator, and root and vapor barriers. Extensive green roofs are heavier, higher in maintenance, usually contain trees and shrubs, require irrigation, and could be designed for human recreation. A figure showing the typical green roof specifications and a detailed comparison table between the extensive and intensive green roof designs are shown in Appendix C.

The proposed green roof solution prepared for the CMB for their consideration consists of 6 inches perennial vegetative layer, 6 inches loamy sand growing medium, 0.098 inches geotextile used as the filter membrane, 2 inches drainage mat, 0.15 inches root barrier, 1.57 inches thermal insulator, and 0.039 inches vapor barrier. The geotextile allows excess water to flow to the drainage mat while preventing any soil particles from leaving the system and clogging the drain. The root barrier protects the thermal insulator and the vapor barrier by preventing plant roots to penetrate through them causing leaks. The thermal insulator helps the building conserve more energy, and the vapor barrier prevents moisture and humidity to pass through the buildings' ceiling. 


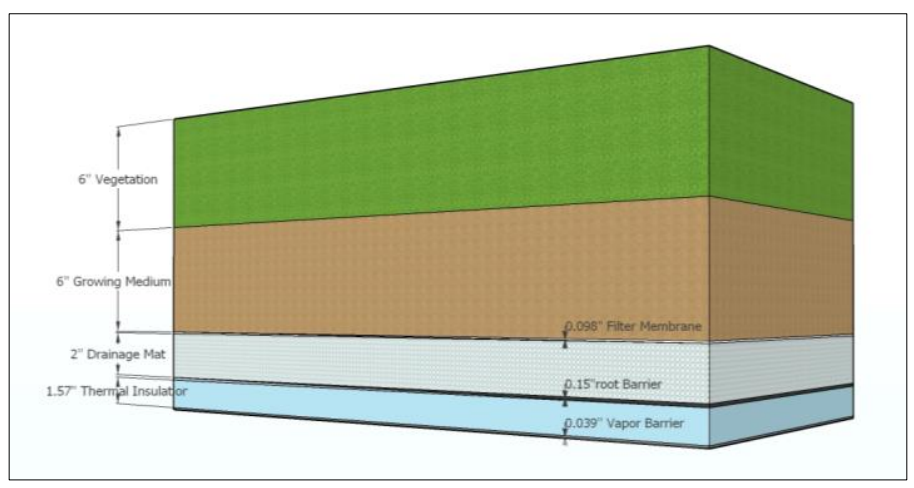

Figure 3-10. Green Roof Proposed Solution

\subsubsection{Grassed Swale Proposed Solution}

Grassed swale is a shallow sloped channel, usually trapezoidal, designed to attenuate and infiltrate runoff volume. Grassed swale could be designed with underdrain if water recycling is desired. The grassed swale design consists of a grass layer followed by a filter media. However, if an underdrain is to be included in the design, a subsurface infiltration trench must be added, which will also increase runoff control and improve the grassed swale efficiency in reducing contaminants. The proposed solution consists of a 6inch switchgrass surface layer followed by 20 -inch loamy sand filter media. The swale has a $2 \%$ longitudinal slope and 3:1 side slope. Figures comparing the differences between grassed swale with underdrain and without underdrain are presented in Appendix C.

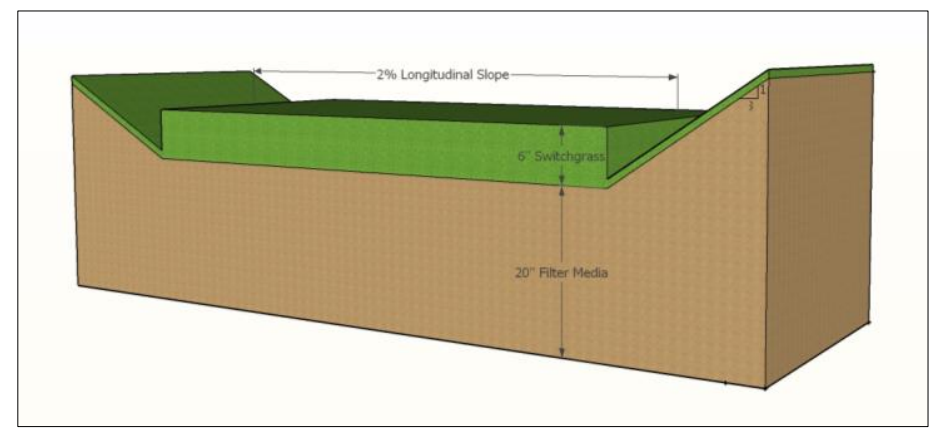

Figure 3-11. Grassed Swale Proposed Solution 


\subsubsection{Rain Barrel Proposed Solution}

Rain barrel is an efficient cost-effective LIDI that reduces stormwater runoff by capturing and storing roof runoff. After the collection process, water could be slowly released and drained to a pervious area or stored for future use, such as on-site irrigation. The main advantage of rain barrels is that it collects water from roofs of any size, shape and function.

The proposed rain barrel solution is a cylindrical barrel that has a diameter of 23 inches and a height of 35 inches with a capacity of 53 gallons. A downspout will drain runoff from the rooftop to the rain barrel. The top of the rain barrel, where the downspout is attached, should contain a screen to prevent dirt particles or insects from entering the barrel. The rain barrel should be elevated to increase water pressure in the barrel when hose-irrigation is desired. Rain barrel sketch along with a photo example of what it looks like in the real world are shown in Appendix C.

\subsubsection{Pervious Concrete Proposed Solution}

Porous pavements are alternative paving surfaces that allow stormwater runoff to filter through voids in the pavement surface into an underlying stone reservoir, where it is temporarily stored and/or infiltrated [50]. Porous pavement has several surface layer options, such as pervious concrete, pervious asphalt, or permeable interlocking concrete pavers. Although the surface layer material may differ, porous pavement design typically consists of the same layers; surface pavement layer, reservoir layer, and filter layer. The proposed solution consists of a 5-inch pervious concrete surface layer, 12-inch crushed stone reservoir ( 1 1/2 inch in size), and 4-inch coarse sand filter layer (0.04 inch in size). A 
comparison table of the three porous pavement types along with design specifications of each is shown in Appendix C.

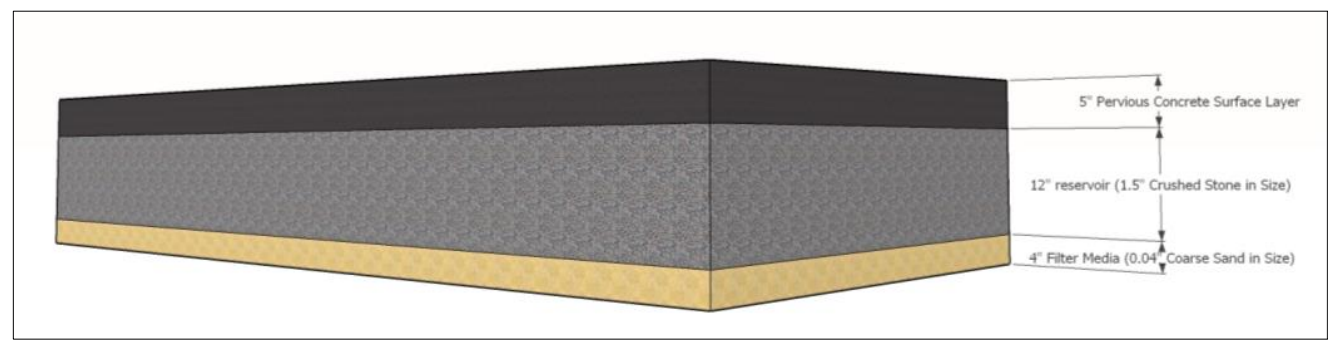

Figure 3-12. Pervious Concrete Proposed Solution 
Table 3-6. LIDI and GI Design Parameters

\begin{tabular}{|c|c|c|c|c|c|c|c|}
\hline Porous Pavement & & Green Roof & & Bioretention Cell & & Grassed Swale & \\
\hline Surface layer & & Surface layer & & Surface layer & & Surface layer & \\
\hline Berm height (in) & 0.1 & Berm height (in) & 3 & Berm height (in) & 4 & Berm height (in) & 6 \\
\hline Vegetation volume fraction & 0 & Vegetation volume fraction & 0.1 & Vegetation volume fraction & 0.1 & Vegetation volume fraction & 0.1 \\
\hline Surface roughness (Manning $\mathrm{n}$ ) & 0.01 & Surface roughness (Manning $\mathrm{n}$ ) & 0.1 & Surface roughness (Manning $\mathrm{n}$ ) & 0.1 & Surface roughness (Manning $\mathrm{n}$ ) & 0.05 \\
\hline Surface slope (\%) & 0 & Surface slope (\%) & 0 & Surface slope (\%) & 0 & Surface slope (\%) & 2 \\
\hline Pavement layer & & Soil layer & & Soil layer & & Soil layer & \\
\hline Thickness (in) & 5 & Thickness (in) & 6 & Thickness (in) & 24 & Thickness (in) & 20 \\
\hline Void ratio & 0.25 & Porosity (volume fraction) & 0.44 & Porosity (volume fraction) & 0.44 & Porosity (volume fraction) & 0.44 \\
\hline Impervious surface fraction & 0 & Field capacity (volume fraction) & 0.1 & Field capacity (volume fraction) & 0.1 & Field capacity (volume fraction) & 0.1 \\
\hline Permeability (in/hr) & 85 & Wilting point (volume fraction) & 0 & Wilting point (volume fraction) & 0 & Wilting point (volume fraction) & 0 \\
\hline Clogging factor & 0 & Seepage rate (in/hr) & 0 & Seepage rate (in/hr) & 1.18 & Seepage rate (in/hr) & 1.18 \\
\hline Reservoir layer & & Conductivity slope & 53 & Conductivity slope & 53 & Conductivity slope & 53 \\
\hline Thickness (in) & 12 & Suction head (in) & 2.4 & Suction head (in) & 2.4 & Suction head (in) & 2.4 \\
\hline Void ratio & 0.4 & Drainage mat & & Storage layer & & Storage layer & \\
\hline Seepage rate (in/hr) & 900 & Thickness (in) & 2 & Thickness (in) & 6 & Seepage rate (in/hr) & 4.74 \\
\hline Clogging factor & 0 & Void fraction & 0.6 & Void ratio & 0.4 & & \\
\hline Filter layer & & Surface roughness (Manning $\mathrm{n}$ ) & 0.02 & Seepage rate (in/hr) & 900 & & \\
\hline Thickness (in) & 4 & Rin Barrel & & Clogging factor & 0 & & \\
\hline Porosity (volume fraction) & 0.34 & Storage & & & & & \\
\hline Field capacity (volume fraction) & 0.06 & Thickness (in) & 36 & & & & \\
\hline Wilting point (volume fraction) & 0 & Drain & & & & & \\
\hline Seepage rate (in/hr) & 4.74 & Flow Efficiency (in/hr) & 0 & & & & \\
\hline Conductivity slope & 48 & Flow Exponent & 0.5 & & & & \\
\hline Suction head (in) & 1.93 & Offset Height (in) & 6 & & & & \\
\hline
\end{tabular}




\subsubsection{Low Impact Development and Green Infrastructure Optimization}

InfoSWMM SUSTAIN was used to optimize the LIDI and GI designs created in part I of modeling and designed in part II. This was done by setting optimization targets of runoff or pollutant reduction or both. The optimization run was simulated for the 5year, 24-hour storm event. The advantages in optimizing the LIDI and GI designs were that the optimizer creates a list of the most cost-effective designs that when combined, meet the runoff and pollutant reduction targets. Scatter search and non-dominated sorting genetic algorithm (NSGA - II) are the two optimization techniques available to run the optimizer. Table 3-7 shows the specifications of the optimization run created in InfoSWMM SUSTAIN.

Table 3-7. Optimization Run Specifications

\begin{tabular}{|l|l|}
\hline \multirow{2}{*}{ Optimization targets } & Runoff reduction: 20\% \\
\cline { 2 - 2 } & Pollutant reduction: 40\% \\
\hline Optimization technique & Scatter search \\
\hline Maximum iterations & 5 \\
\hline Maximum model runs & 3584 \\
\hline Number of best solutions & 5 \\
\hline Maximum budget, US \$ & $3,000,000$ \\
\hline
\end{tabular}

\subsection{EPA SWMM 5.1 Modeling of Indian Creek Drive Location}

EPA SWMM 5.1 was used to model the Indian Creek location to exemplify the capabilities of a publicly available stormwater computer model in designing LIDI and GI. Because of the recent implementation of the wall between the Drive and the Creek, runoff from the street was not considered a design parameter. The LIDI and GI designed 
solutions were modeled to accommodate flooding as a result of elevated water level from the creek during a simulated king tide event. Highest recorded king tide in the CMB is 2.3 feet in reference to the North American vertical datum 1988 (NAVD 88). To create the king tide scenario, 2.3 feet of water was modeled to elevate gradually in 2 hours of one-minute increments in Indian Creek. The subcatchment created for this location is 20 feet wide and 200 feet long with an area of 0.09 acre and slope of $0 \%$. Figure 3-13 shows the modeling setup for the study site.

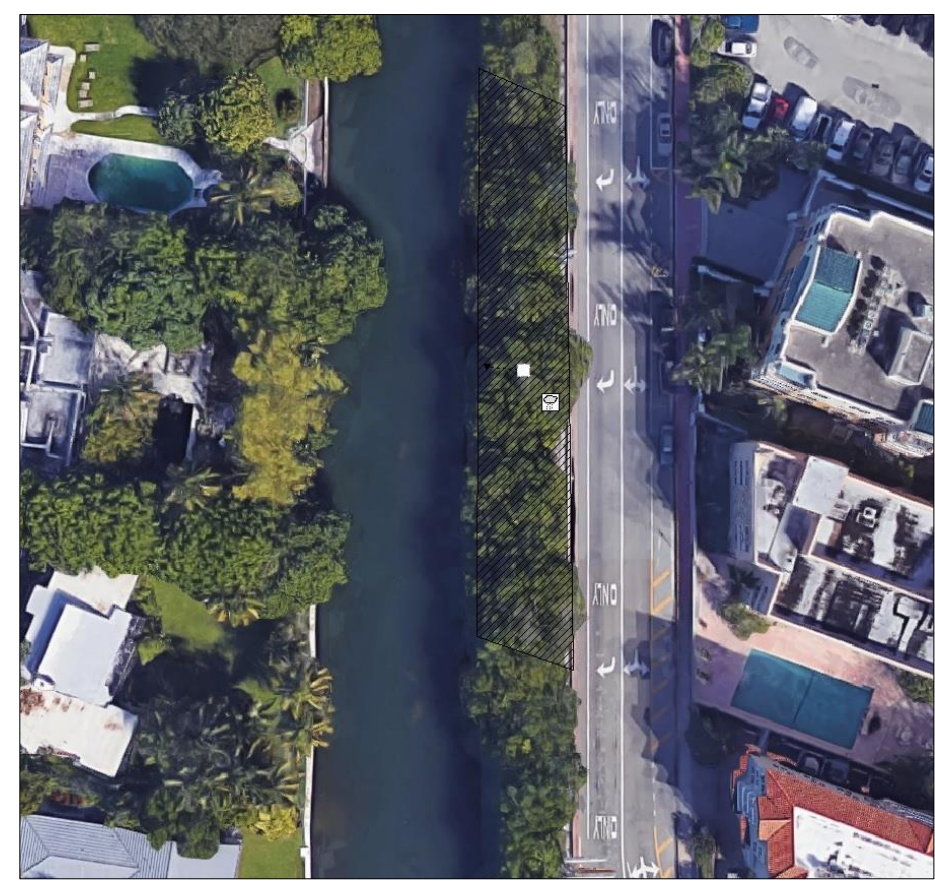

Figure 3-13. Indian Creek Drive Location Modeling Setup (Background Map Retrieved from [12]) 


\section{RESULTS AND DISCUSSION}

\subsection{Siting Manager Results}

Part I of modeling involved utilizing the siting manager tool in InfoSWMM SUSTAIN to specify potential locations for LIDI and GI implementation based on GIS data of ground conditions and defined set of rules. Five neighborhoods were analyzed; South Pointe, Flamingo Lummus, City Center, Bayshore, and North Shore, with the latter being the study site in which LIDI and GI were further analyzed for runoff and contaminant reduction including a cost-benefit analysis. The siting manager tool revealed the suitability to implement 288 LIDI and GI in Flamingo Lummus, 87 in South Pointe, 121 in City Center, 350 in Bayshore, and 139 in North Shore. The seven recommended LIDI and GI for Flamingo Lummus, South Pointe, City Center and Bayshore were bioretention cells, rain barrels, grassed swales, infiltration trenches, sand filters, green roofs, and porous pavements. Results from North Shore neighborhood revealed its suitability to host five types of LIDI and GI only, which are bioretention cells, rain barrels, grassed swales, green roofs, and porous pavements.

It is noticeable that green roof dominates over the rest of LIDI and GI. That is because buildings in general are available in abundance in heavily urbanized cities such as the CMB Porous pavement also occurred often as a type, as there is an entire urban land use code specified for parking lots, in which the impervious part of a parking lot is mainly targeted by porous pavement placement. The only GI that did not qualify for the siting manager results was constructed wetland. That is because the recommended surface area for a constructed wetland placement has to exceed 25 acres. It does not appear that such surface area of open land is present in the CMB. 


\subsubsection{Flamingo Lummus Neighborhood}

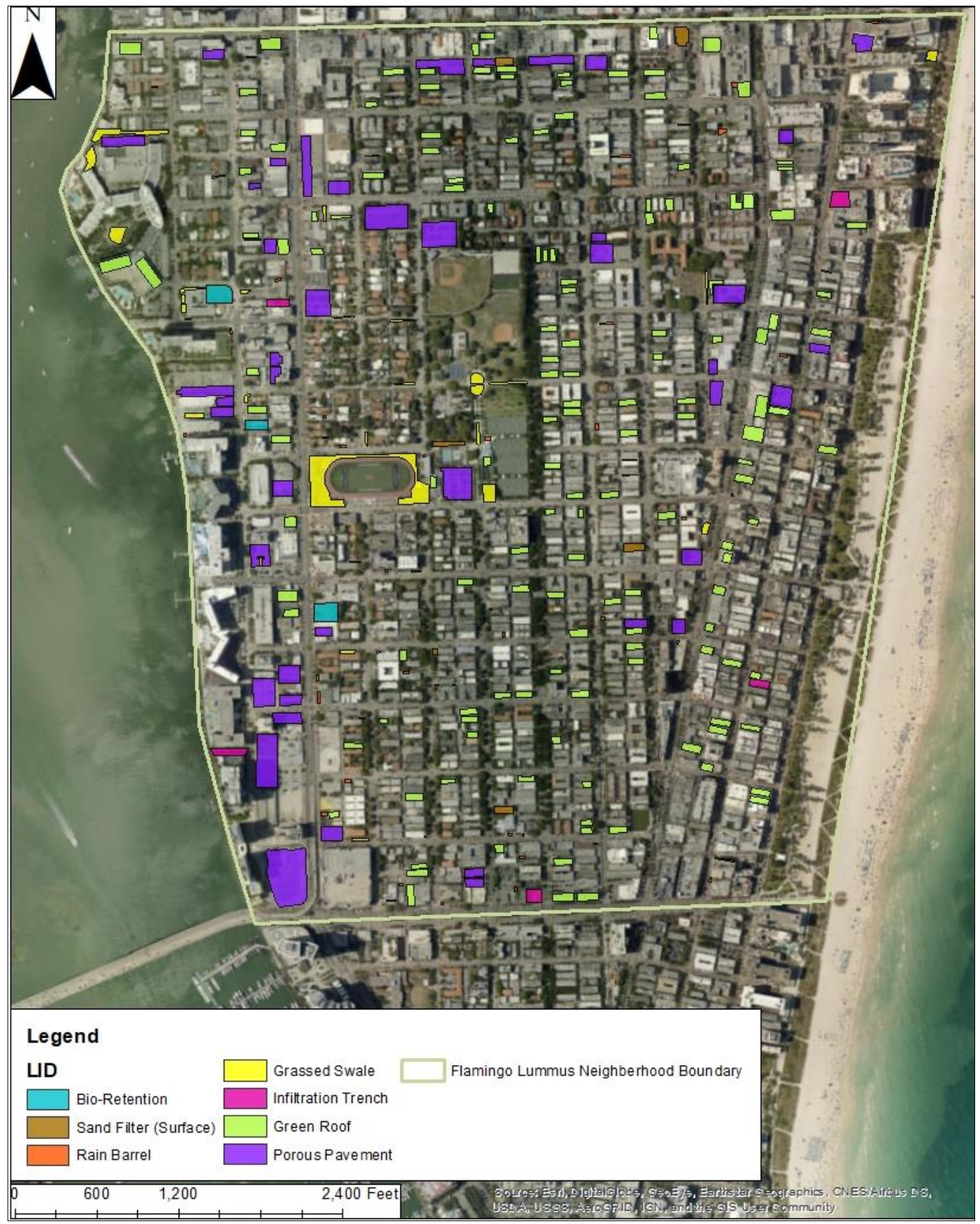

Figure 4-1. Flamingo Lummus Neighborhood Siting Results (Background Map Retrieved from[6]) 


\subsubsection{South Pointe Neighborhood}

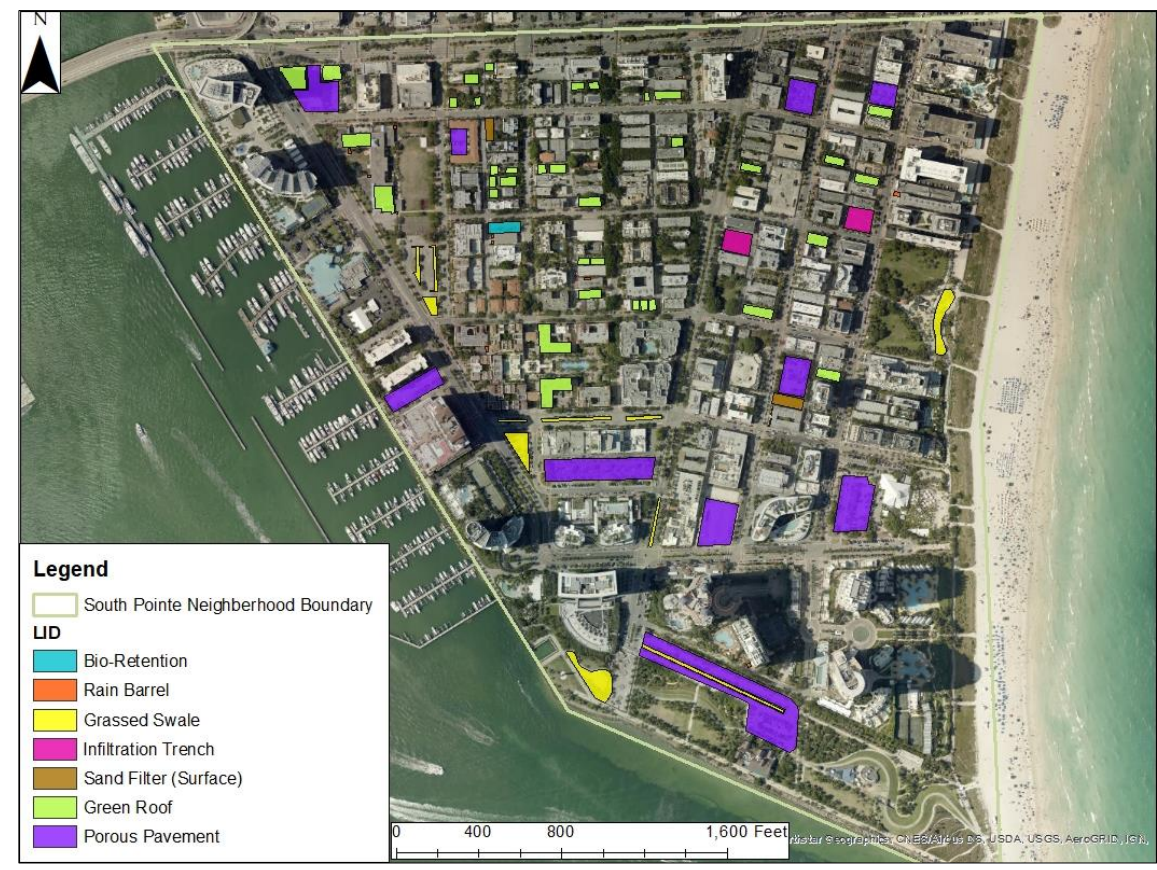

Figure 4-2. South Pointe Neighborhood Siting Results (Background Map Retrieved from [6])

\subsubsection{City Center Neighborhood}

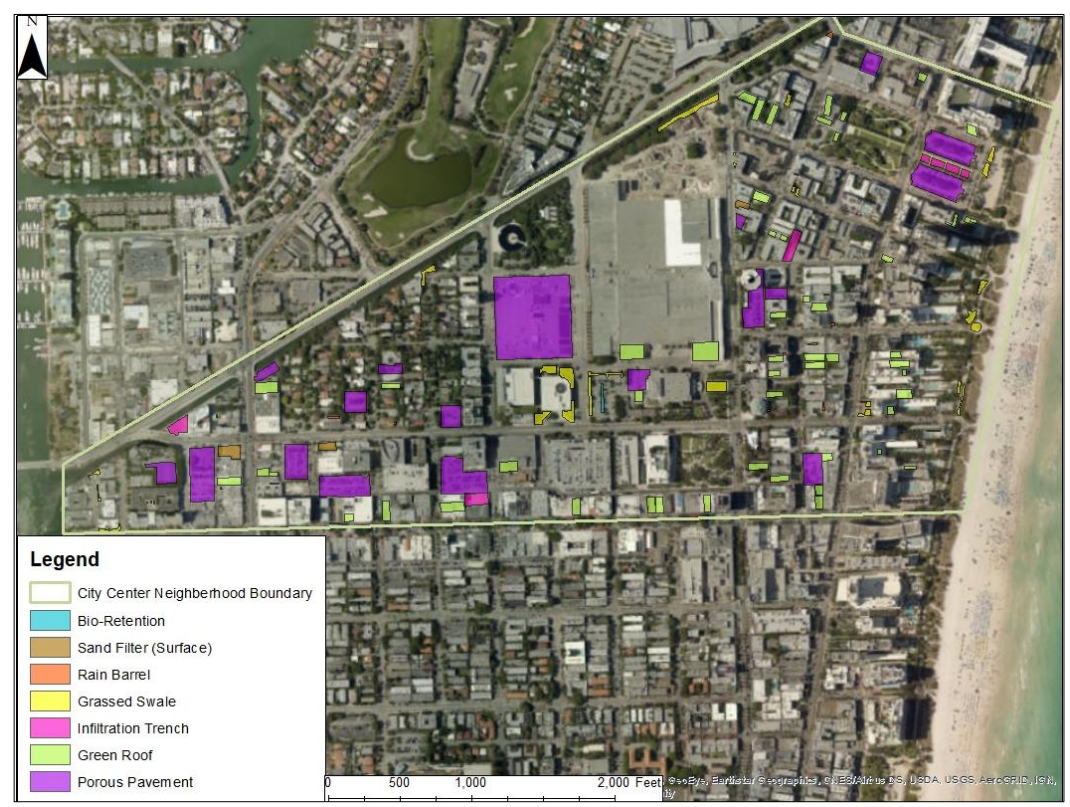

Figure 4-3. City Center Neighborhood Siting Results (Background Map Retrieved from [6]) 


\subsubsection{Bayshore Neighborhood}

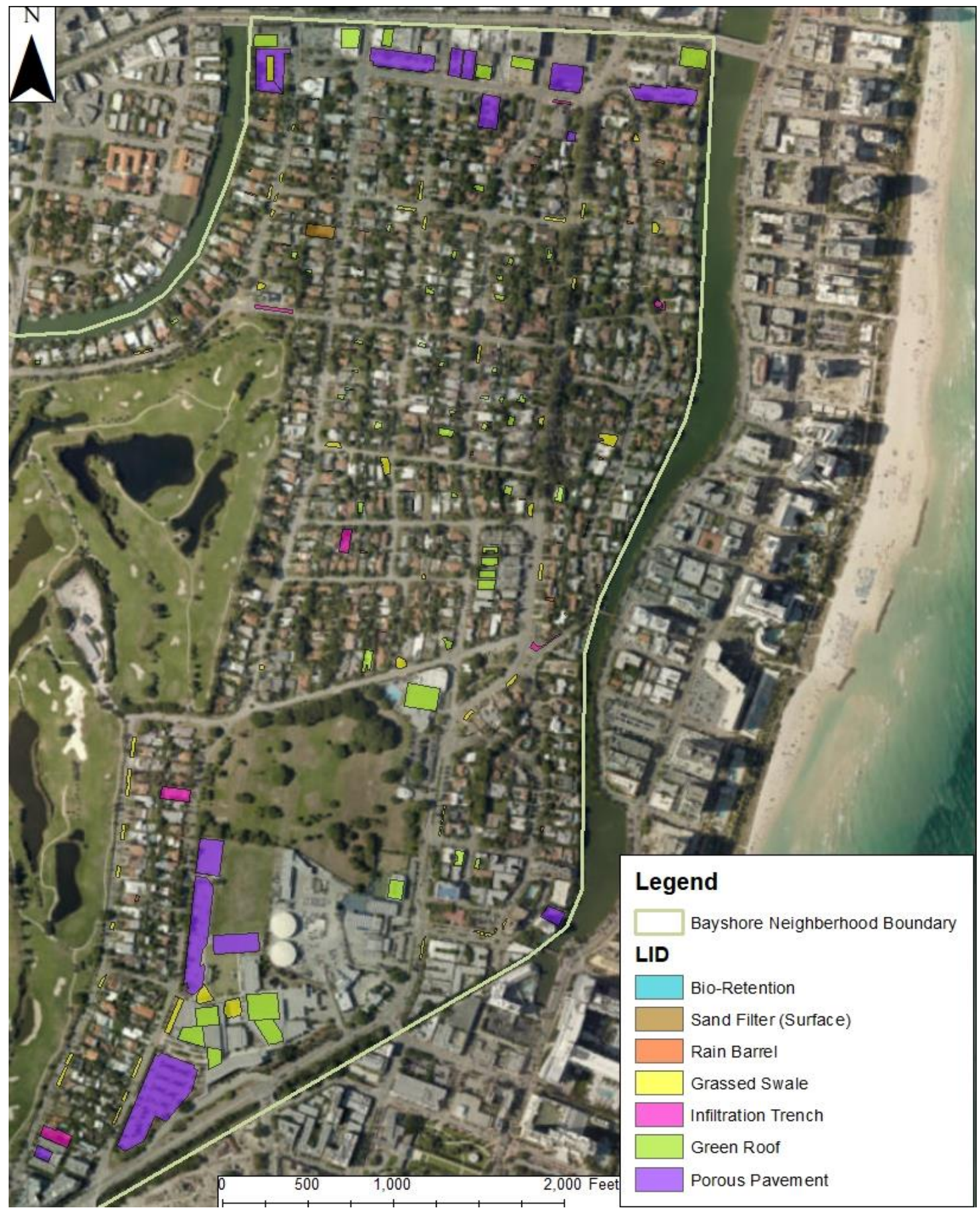

Figure 4-4. Bayshore Siting Results Part I

(Background Map Retrieved from [6]) 


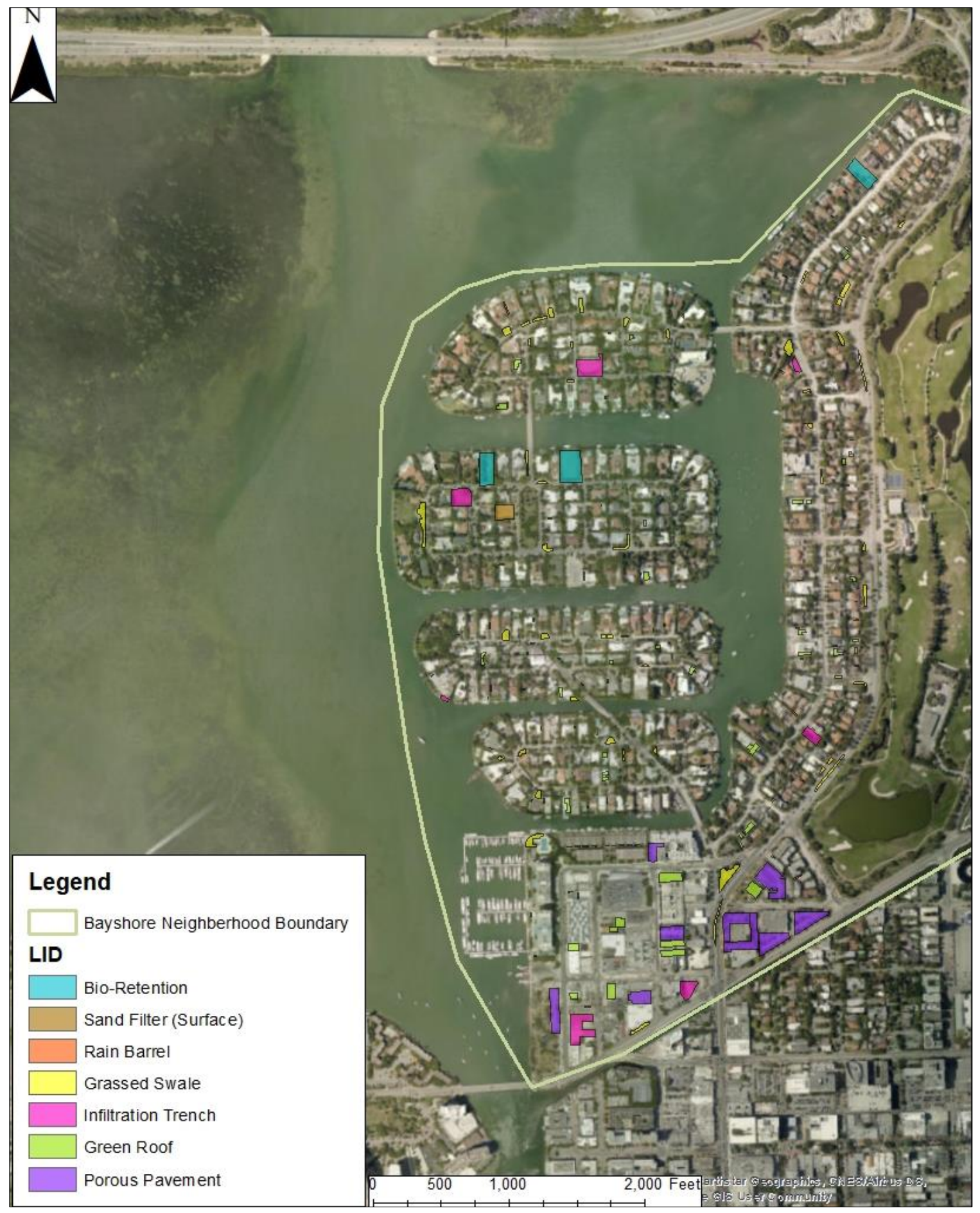

Figure 4-5. Bayshore Siting Results Part II

(Background Map Retrieved from [6]) 


\subsubsection{North Shore Neighborhood}

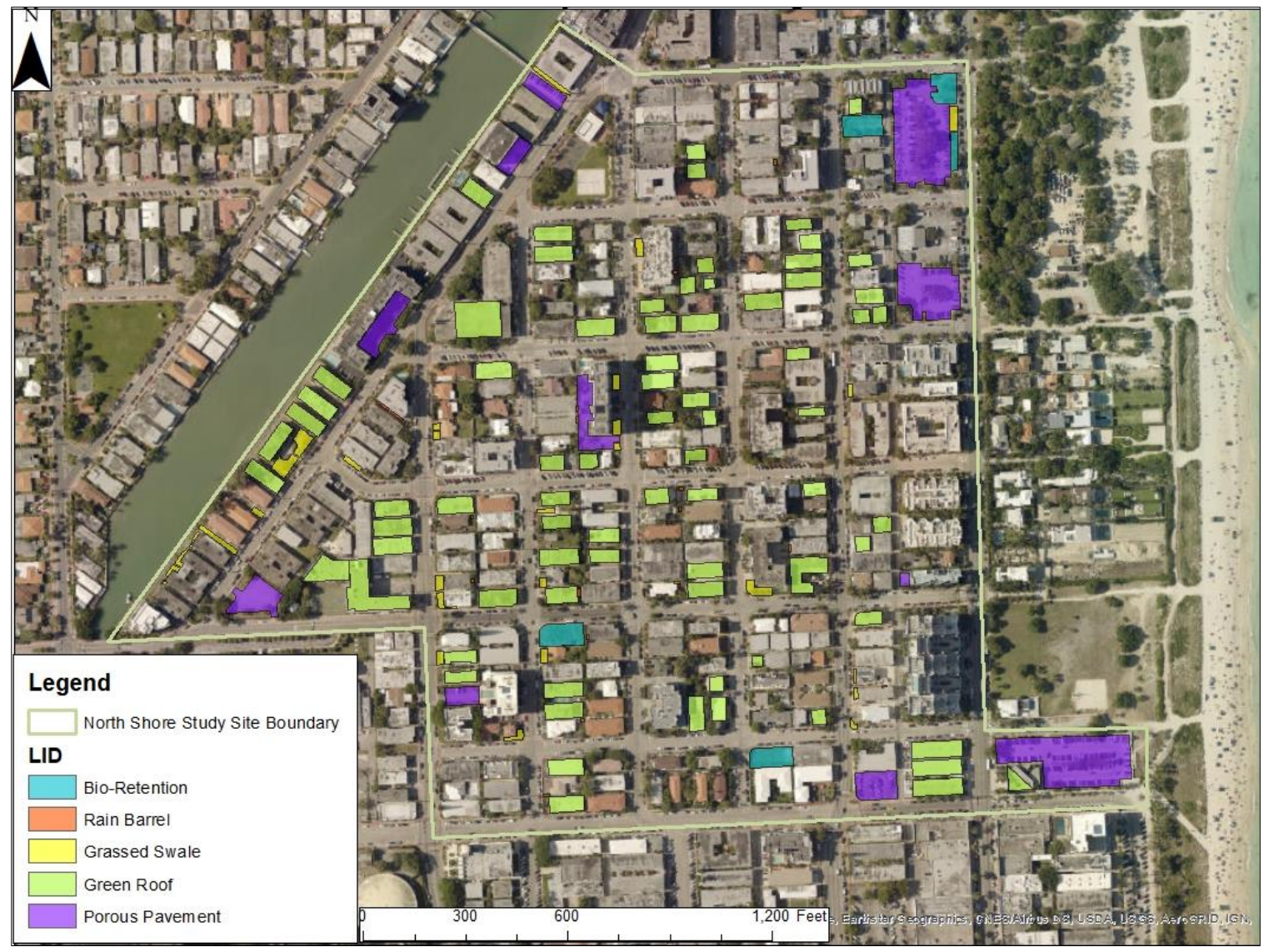

Figure 4-6 North Shore Neighborhood Siting Results

(Background Map Retrieved from [6])

\subsection{Pre-development Scenario Results}

The pre-development scenario was modeled using the subcatchment

characteristics and simulation options explained in part II modeling setup in chapter three of this thesis. Pre-development scenario refers to the current conditions of the study site before adding the LIDI and GI recommended by the siting manager. The purpose of modeling the pre-development scenario is to compare the resulting runoff and stormwater quality loadings to the post-development conditions so as to investigate the effectiveness 
of the implemented LIDI and GI. The pre-development run for the 5, 10, and 100-year, 24-hour storm events are presented below.

Table 4-1. Pre-development 5-year, 24-hour Storm Event Continuity Runoff Quantity

\begin{tabular}{|c|c|c|}
\hline Item & $\begin{array}{c}\text { Volume } \\
\text { [acre-ft] }\end{array}$ & $\begin{array}{c}\text { Depth } \\
\text { [in] }\end{array}$ \\
\hline Total Precipitation & 58.900 & 7.440 \\
\hline Evaporation Loss & 1.964 & 0.248 \\
\hline Infiltration Loss & 3.770 & 0.476 \\
\hline Surface Runoff & 51.938 & 6.561 \\
\hline Continuity Error [\%] & -0.025 & -0.025 \\
\hline
\end{tabular}

Table 4-2. Pre-development 5-year, 24-hour Storm Event Continuity Runoff Quality

\begin{tabular}{|c|c|c|c|}
\hline Item & $\begin{array}{c}\text { POLLUTNT-1 } \\
\text { [lbs] }\end{array}$ & $\begin{array}{c}\text { POLLUTNT-2 } \\
\text { (lbs] }\end{array}$ & $\begin{array}{c}\text { POLLUTNT-3 } \\
\text { [lbs] }\end{array}$ \\
\hline Initial Buildup & 0.000 & 0.000 & 0.000 \\
\hline Surface Buildup & 7.587 & 0.190 & 1.710 \\
\hline Wet Deposition & 0.000 & 0.000 & 0.000 \\
\hline Sweeping Removal & 0.000 & 0.000 & 0.000 \\
\hline Surface Runoff & 7.587 & 0.190 & 1.710 \\
\hline Remaining Buildup & 0.000 & 0.000 & 0.000 \\
\hline Continuity Error (\%) & 0.000 & 0.000 & 0.000 \\
\hline
\end{tabular}

Pollutnt-1;TSS, Pollutnt-2; BOD, Pollutnt-3;COD.

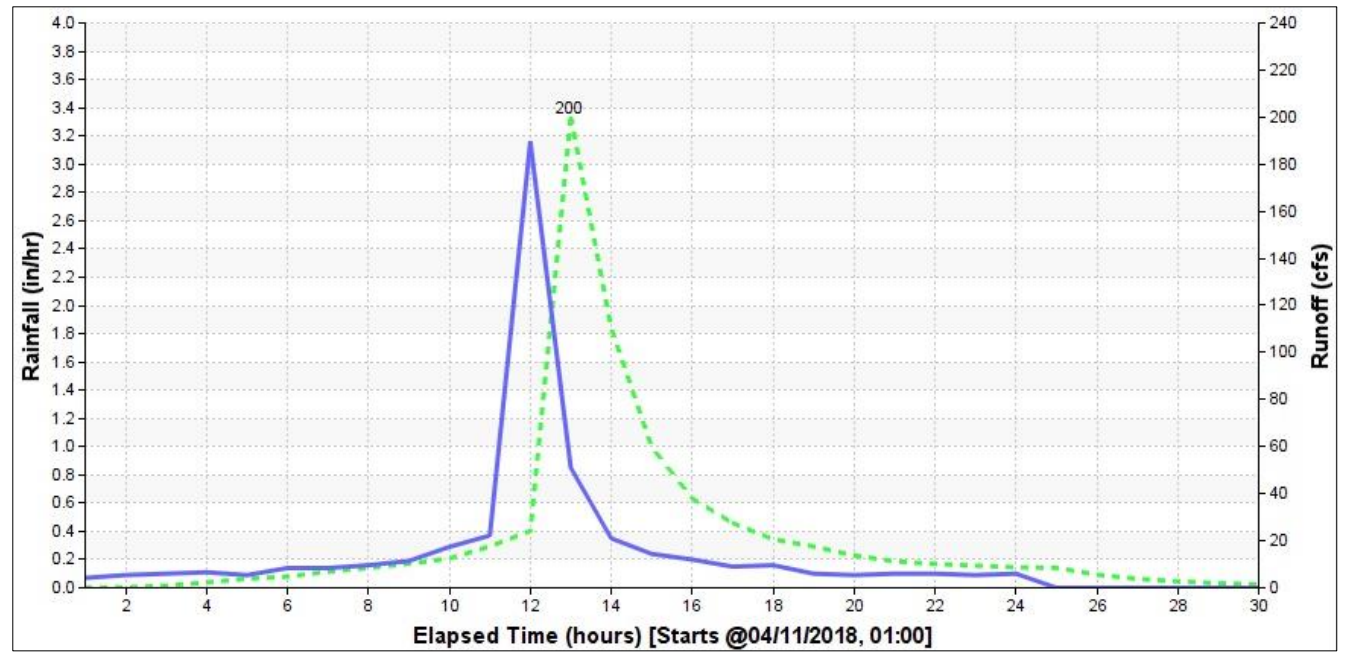

Figure 4-7. Pre-development 5-year, 24-hour Rainfall-Runoff Graph (一: Rainfall, $\because " \because$ : Runoff ) 
Table 4-3. Pre-development 10-year, 24-hour Storm Event Continuity Runoff Quantity

\begin{tabular}{|c|c|c|}
\hline Item & $\begin{array}{c}\text { Volume } \\
\text { [acre-ft] }\end{array}$ & $\begin{array}{c}\text { Depth } \\
\text { [in] }\end{array}$ \\
\hline Total Precipitation & 68.400 & 8.640 \\
\hline Evaporation Loss & 1.964 & 0.248 \\
\hline Infiltration Loss & 4.378 & 0.553 \\
\hline Surface Runoff & 60.775 & 7.677 \\
\hline Continuity Error (\%) & -0.026 & -0.026 \\
\hline
\end{tabular}

Table 4-4. Pre-development 10-year, 24-hour Storm Event Continuity Runoff Quality

\begin{tabular}{|c|c|c|c|}
\hline Item & $\begin{array}{c}\text { POLLUTNT-1 } \\
\text { [lbs] }\end{array}$ & $\begin{array}{c}\text { POLLUTNT-2 } \\
\text { (lbs) }\end{array}$ & $\begin{array}{c}\text { POLLUTNT-3 } \\
\text { (lbs) }\end{array}$ \\
\hline Initial Buildup & 0.000 & 0.000 & 0.000 \\
\hline Surface Buildup & 6.597 & 0.190 & 1.710 \\
\hline Wet Deposition & 0.000 & 0.000 & 0.000 \\
\hline Sweeping Removal & 0.000 & 0.000 & 0.000 \\
\hline Surface Runoff & 6.597 & 0.190 & 1.710 \\
\hline Remaining Buildup & 0.000 & 0.000 & 0.000 \\
\hline Continuity Error (\%) & 0.000 & 0.000 & 0.000 \\
\hline
\end{tabular}

Pollutnt-1;TSS, Pollutnt-2; BOD, Pollutnt-3;COD.

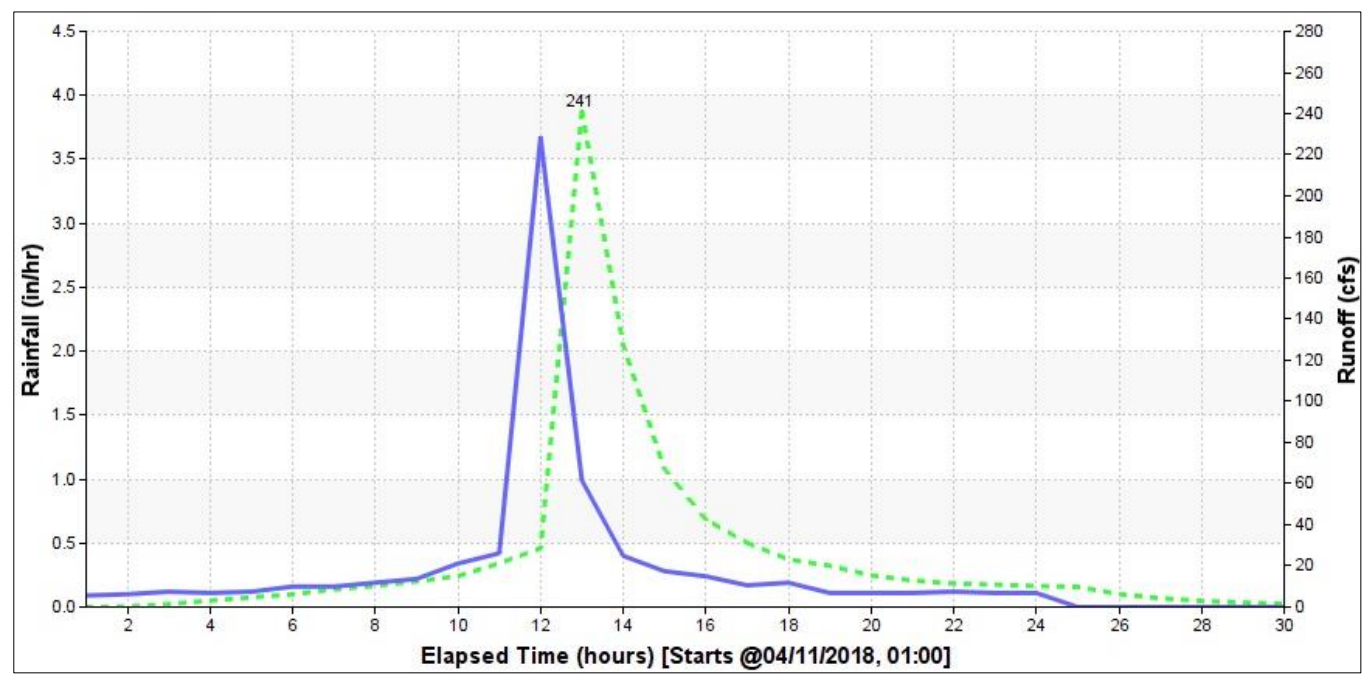

Figure 4-8. Pre-development 10-year, 24-hour Rainfall-Runoff Graph ( - : Rainfall, $₫ \pm \approx$ : Runoff ) 
Table 4-5. Pre-development 100-year, 24-hour Storm Event Continuity Runoff Quantity

\begin{tabular}{|c|c|c|}
\hline Item & $\begin{array}{c}\text { Volume } \\
\text { [acre-ft] }\end{array}$ & $\begin{array}{c}\text { Depth } \\
\text { [in] }\end{array}$ \\
\cline { 1 - 1 } Total Precipitation & 106.400 & 13.440 \\
\hline Evaporation Loss & 1.970 & 0.249 \\
\hline Infiltration Loss & 6.723 & 0.849 \\
\hline Surface Runoff & 96.251 & 12.158 \\
\hline Continuity Error [\%] & -0.030 & -0.030 \\
\hline
\end{tabular}

Table 4-6. Pre-development 100-year, 24-hour Storm Event Continuity Runoff Quality

\begin{tabular}{|c|c|c|c|}
\hline Item & $\begin{array}{c}\text { POLLUTNT-1 } \\
\text { (lbs) }\end{array}$ & $\begin{array}{c}\text { POLLUTNT-2 } \\
\text { (lbs) }\end{array}$ & $\begin{array}{c}\text { POLLUTNT-3 } \\
\text { (lbs) }\end{array}$ \\
\hline Initial Buildup & 0.000 & 0.000 & 0.000 \\
\hline Surface Buildup & 5.608 & 0.190 & 1.710 \\
\hline Wet Deposition & 0.000 & 0.000 & 0.000 \\
\hline Sweeping Removal & 0.000 & 0.000 & 0.000 \\
\hline Surface Runoff & 5.608 & 0.190 & 1.710 \\
\hline Remaining Buildup & 0.000 & 0.000 & 0.000 \\
\hline Continuity Error (\%) & 0.000 & 0.000 & 0.000 \\
\hline
\end{tabular}

Pollutnt-1;TSS, Pollutnt-2; BOD, Pollutnt-3;COD.

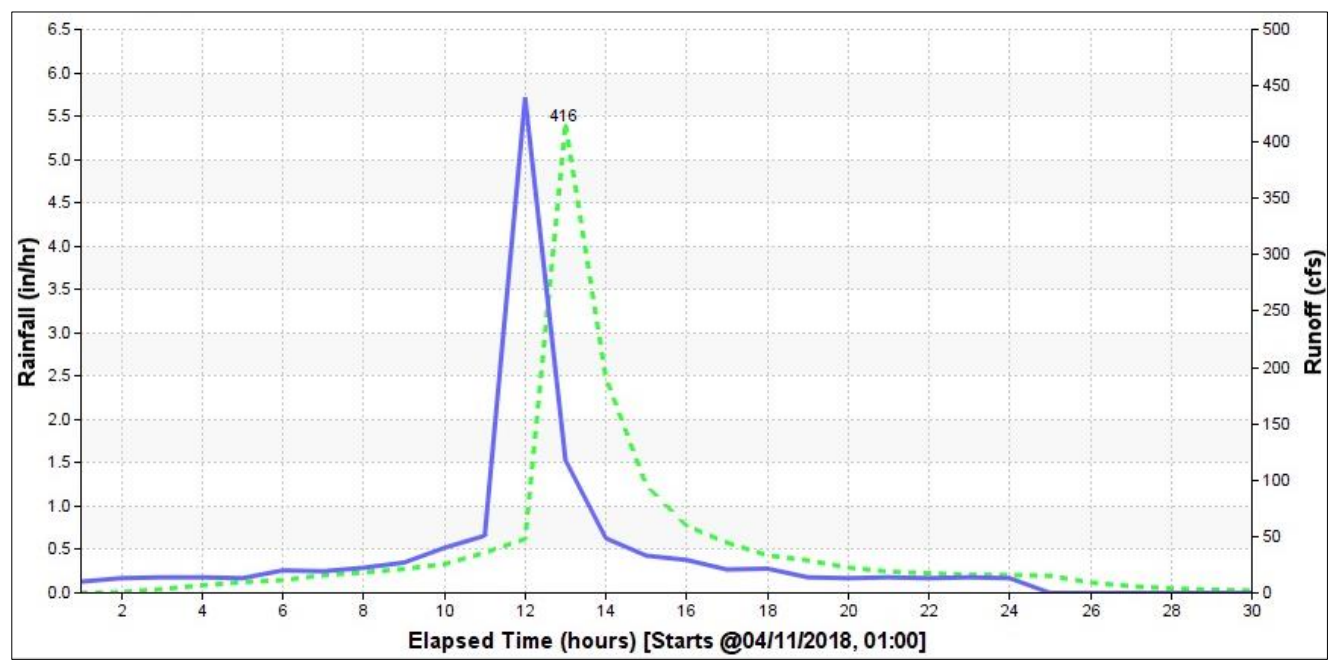

Figure 4-9. Pre-development 100-year, 24-hour Rainfall-Runoff Graph ( - : Rainfall, $\square:$ Runoff ) 
All three storm events resulted in excess surface runoff. This was expected as the CMB is almost completely urbanized and specifically the North Shore study site with impervious percentage of 93.6. Calculated peak runoff values for the 5, 10, and 100-year, 24-hour storm events were $200 \mathrm{cfs}, 241 \mathrm{cfs}$, and 416 cfs respectively. Results showed that there is no change in evaporation loss between the 5 and 10 -year storm events $(0.248$ inches $)$, and a very small change when compared to the 100 -year storm event $(0.249$ inches). Results also showed that infiltration rate increases as the storm intensity increases; 0.476 inches, 0.553 inches, and 0.849 inches respectively. However, the relationship between infiltration rate and storm intensity could be wrongly interpreted. There is no direct relationship between storm intensity and infiltration rate. Infiltration rate is a soil property and is defined by the specific soil texture and its parameters. The reason the modeling results showed the increased infiltration rate as the storm gets stronger is because the entire North Shore neighborhood has the same type A soil. Therefore, as the storm intensity increases, precipitation increases, and soil moisture content increases causing higher infiltration rates.

Water quality constituents were modeled using the power function for buildup and EMC function for washoff. Optional parameters, such as concentration in rain and street sweeping removal efficiency were ignored. Results showed that TSS loading reduces as the storm intensity increases $(7.587 \mathrm{lb}, 6.597 \mathrm{lb}$, and $5.608 \mathrm{lb}$ respectively), whereas BOD and COD loadings were the same for all three storm events at $0.19 \mathrm{lb}$ and $1.71 \mathrm{lb}$. Although buildup rate was specified to be the same for all three contaminants, the loading per unit area differs significantly as TSS typical loadings exceed that of BOD and 
COD in stormwater runoff, which justifies the steadiness of the low concentrated pollutants.

\subsection{Post-development Scenario Results}

The InfoSWMM SUSTAIN siting manager results for the North Shore neighborhood, which includes 139 LIDI and GI of green roofs, bioretention cells, grassed swales, and rain barrels, were added to InfoSWMM browser to run the model for the post-development scenario. The 139 LIDI and GI ID, surface area, and width are listed in Table 7 in Appendix B. After importing the data into InfoSWMM browser, the design parameters specified in Table 3-6 for green roof, bioretention cell, grassed swale and rain barrel were fed to the model. The 5, 10, and 100-year, 24-hour storm events were simulated, and results are shown in the following 3 pages. Results of the postdevelopment scenario run showed significant runoff and pollution reduction compared to pre-development. 
Table 4-7. Post-development 5-year, 24-hour Storm Event Continuity Runoff Quantity

\begin{tabular}{|c|c|c|}
\hline Item & $\begin{array}{c}\text { Volume } \\
\text { (acre-ft] }\end{array}$ & $\begin{array}{c}\text { Depth } \\
\text { (in) }\end{array}$ \\
\cline { 1 - 2 } Total Precipitation & 58.900 & 7.440 \\
\hline Evaporation Loss & 1.736 & 0.219 \\
\cline { 1 - 1 } Infiltration Loss & 11.225 & 1.418 \\
\hline Surface Runoff & 26.843 & 3.391 \\
\hline Continuity Error (\%) & -0.041 & -0.041 \\
\hline
\end{tabular}

Table 4.8- Post-development 5-year, 24-hour Storm Event Continuity Runoff Quality

\begin{tabular}{|c|c|c|c|}
\hline Item & $\begin{array}{c}\text { POLLUTNT-1 } \\
\text { (lbs) }\end{array}$ & $\begin{array}{c}\text { POLLUTNT-2 } \\
\text { (bs) }\end{array}$ & $\begin{array}{c}\text { POLLUTNT-3 } \\
\text { (bs) }\end{array}$ \\
\hline Initial Buildup & 0.000 & 0.000 & 0.000 \\
\hline Surface Buildup & 7.587 & 0.190 & 1.710 \\
\hline Wet Deposition & 0.000 & 0.000 & 0.000 \\
\hline Sweeping Removal & 0.000 & 0.000 & 0.000 \\
\hline BMP Removal & 4.347 & 0.155 & 1.175 \\
\hline Surface Runoff & 3.240 & 0.035 & 0.535 \\
\hline Continuity Error [\%] & 0.000 & 0.000 & 0.000 \\
\hline
\end{tabular}

Pollutnt-1;TSS, Pollutnt-2; BOD, Pollutnt-3;COD.

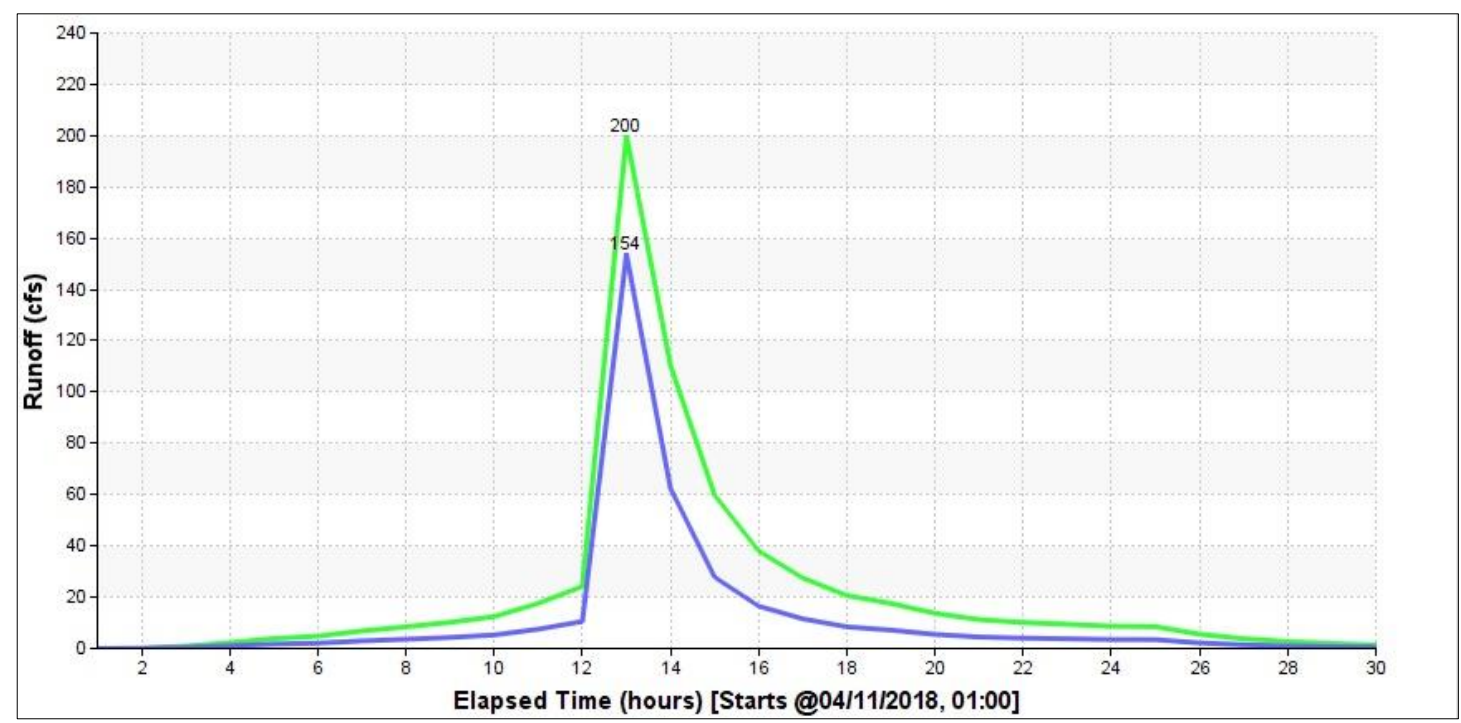

Figure 4-10. Post-development 5-year, 24-hour Runoff Graph (口 : Post-development, - : Pre-development ) 
Table 4-9. Post-development 10-year, 24-hour Storm Event Continuity Runoff Quantity

\begin{tabular}{|c|c|c|}
\hline Item & $\begin{array}{c}\text { Volume } \\
\text { [acre-ft] }\end{array}$ & $\begin{array}{c}\text { Depth } \\
\text { [in] }\end{array}$ \\
\hline Total Precipitation & 68.400 & 8.640 \\
\hline Evaporation Loss & 1.739 & 0.220 \\
\hline Infiltration Loss & 12.936 & 1.634 \\
\hline Surface Runoff & 32.903 & 4.156 \\
\hline Continuity Error (\%) & -0.037 & -0.037 \\
\hline
\end{tabular}

Table 4-10. Post-development 10-year, 24-hour Storm Event Continuity Runoff Quality

\begin{tabular}{|c|c|c|c|}
\hline Item & $\begin{array}{c}\text { POLLUTNT-1 } \\
\text { (lbs] }\end{array}$ & $\begin{array}{c}\text { POLLUTNT-2 } \\
\text { [lbs] }\end{array}$ & $\begin{array}{c}\text { POLLUTNT-3 } \\
\text { [lbs] }\end{array}$ \\
\hline Initial Buildup & 0.000 & 0.000 & 0.000 \\
\hline Surface Buildup & 6.597 & 0.190 & 1.710 \\
\hline Wet Deposition & 0.000 & 0.000 & 0.000 \\
\hline Sweeping Removal & 0.000 & 0.000 & 0.000 \\
\hline BMP Removal & 3.936 & 0.155 & 1.182 \\
\hline Surface Runoff & 2.661 & 0.035 & 0.528 \\
\hline Continuity Error [\%] & 0.000 & 0.000 & 0.000 \\
\hline
\end{tabular}

Pollutnt-1;TSS, Pollutnt-2; BOD, Pollutnt-3;COD.

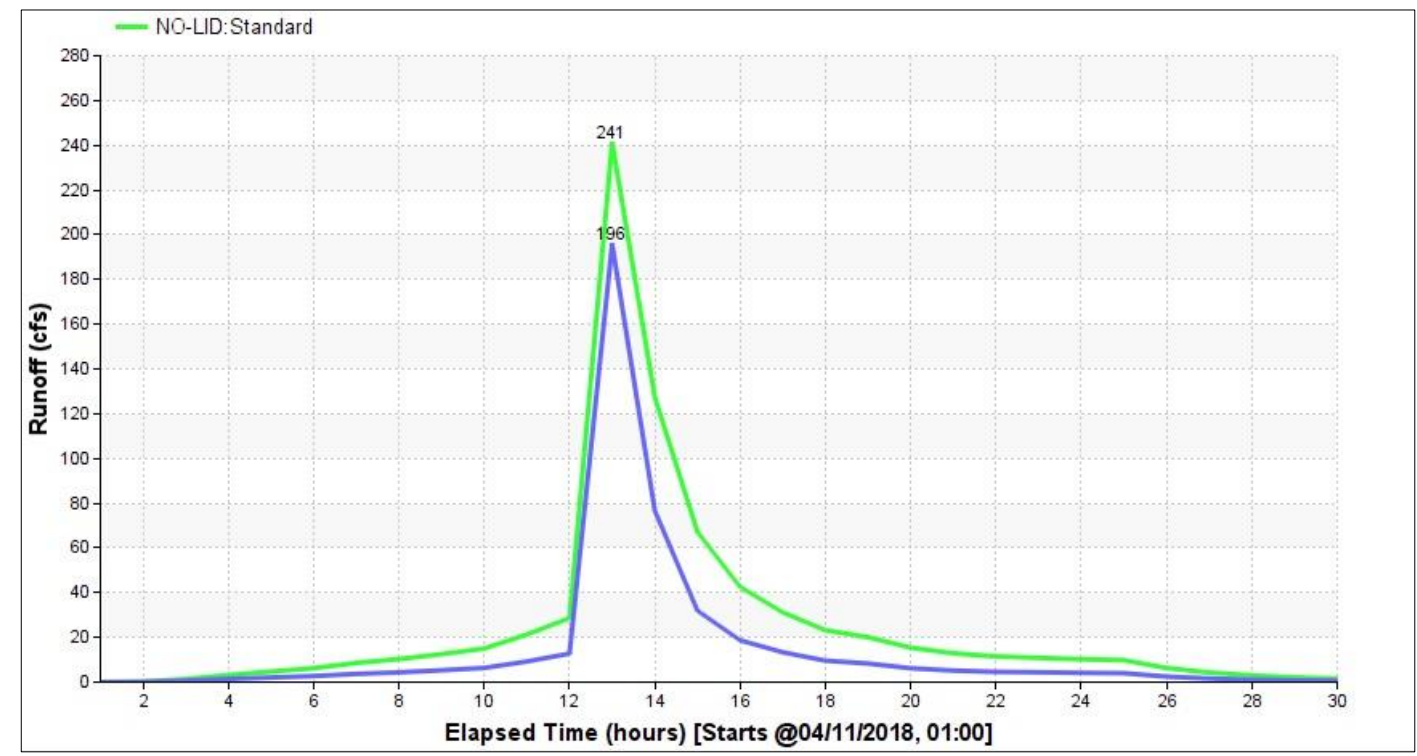

Figure 4-11. Post-development 10-year, 24-hour Runoff Graph (- : Post-development, - : Pre-development ) 
Table 4-11. Post-development 100-year, 24-hour Storm Event Continuity Runoff Quantity

\begin{tabular}{|c|c|c|}
\hline Item & $\begin{array}{c}\text { Volume } \\
\text { [acre-ft] }\end{array}$ & $\begin{array}{c}\text { Depth } \\
\text { [in] }\end{array}$ \\
\hline Total Precipitation & 106.400 & 13.440 \\
\hline Evaporation Loss & 1.757 & 0.222 \\
\hline Infiltration Loss & 19.044 & 2.406 \\
\hline Surface Runoff & 58.721 & 7.417 \\
\hline Continuity Error (\%) & -0.038 & -0.038 \\
\hline
\end{tabular}

Table 4-12. Post-development 100-year, 24-hour Storm Event Continuity Runoff Quality

\begin{tabular}{|c|c|c|c|}
\hline Item & $\begin{array}{c}\text { POLLUTNT-1 } \\
\text { (lbs) }\end{array}$ & $\begin{array}{c}\text { POLLUTNT-2 } \\
\text { (lbs) }\end{array}$ & $\begin{array}{c}\text { POLLUTNT-3 } \\
\text { (bs) }\end{array}$ \\
\hline Initial Buildup & 0.000 & 0.000 & 0.000 \\
\hline Surface Buildup & 5.608 & 0.190 & 1.710 \\
\hline Wet Deposition & 0.000 & 0.000 & 0.000 \\
\hline Sweeping Removal & 0.000 & 0.000 & 0.000 \\
\hline BMP Removal & 3.470 & 0.159 & 1.204 \\
\hline Surface Runoff & 2.138 & 0.031 & 0.506 \\
\hline Remaining Buildup & 0.000 & 0.000 & 0.000 \\
\hline Continuity Error (\%) & 0.000 & 0.000 & 0.000 \\
\hline
\end{tabular}

Pollutnt-1;TSS, Pollutnt-2; BOD, Pollutnt-3;COD.

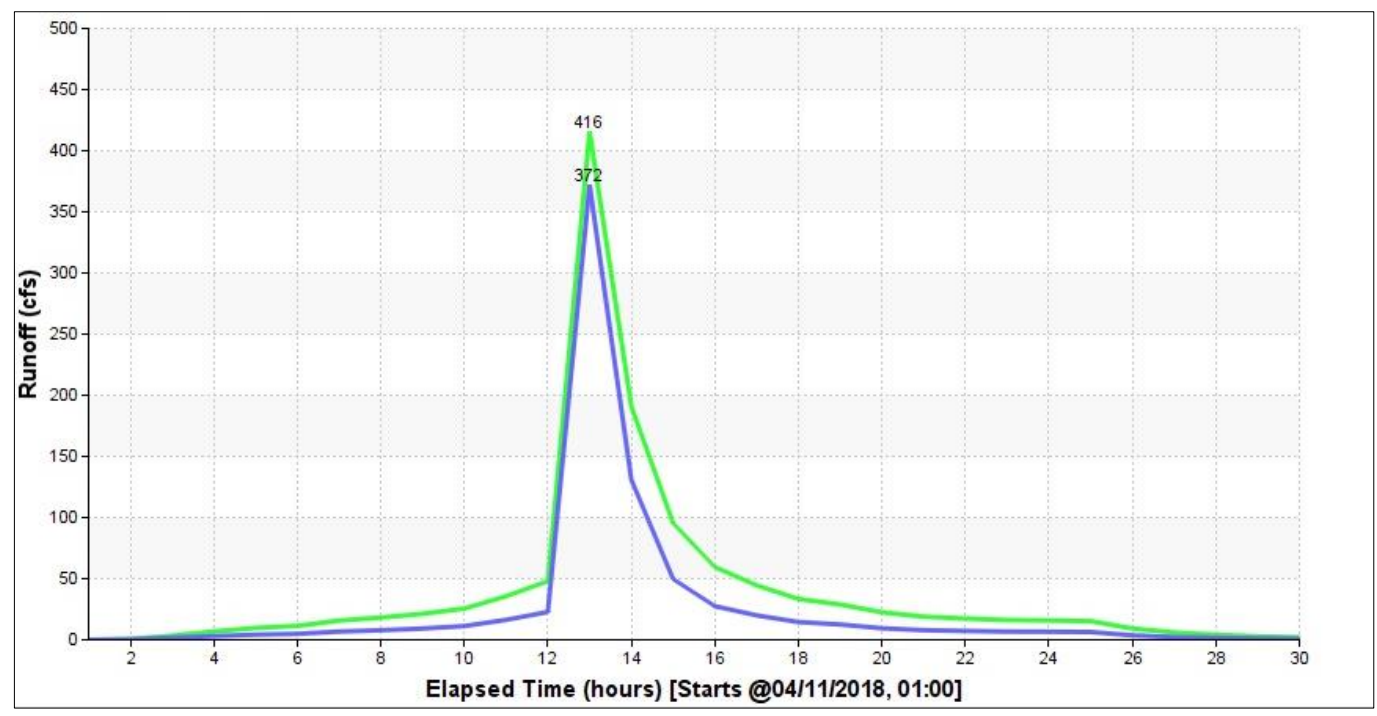

Figure 4-12. Post-development 100-year, 24-hour Runoff Graph (- : Post-development, - : Pre-development ) 
Percent reduction was calculated using equation 8

Percent reduction $=\frac{\text { pre-development result }- \text { post-development result }}{\text { pre-development result }}$

and revealed the following:

1. 5-year, 24-hour storm event runoff depth was reduced by $48 \%$

2. 10-year, 24-hour storm event runoff depth was reduced by $46 \%$

3. 100-year, 24-hour storm event runoff depth was reduced by $39 \%$

4. 5-year 24-hour storm event TSS loading was reduced by $57 \%$

5. 5-year, 24-hour storm event BOD loading was reduced by $82 \%$

6. 5-year, 24-hour storm event COD loading was reduced by $69 \%$

7. 10-year, 24-hour storm event TSS loading was reduced by $60 \%$

8. 10-year, 24-hour storm event BOD loading was reduced by $82 \%$

9. 10-year, 24-hour storm event COD loading was reduced by $69 \%$

10. 100-year, 24-hour storm event TSS loading was reduced by $62 \%$

11. 100-year, 24-hour storm event BOD loading was reduced by $84 \%$

12. 100-year, 24-hour storm event COD loading was reduced by $70 \%$

The calculated percent reductions show an inverse relationship between storm intensity and runoff reduction; as the storm intensity increases, percent reduction in runoff decreases. The calculations also revealed a direct relationship between storm intensity and contaminant loading reduction; as the storm intensity increases, percent reduction in contaminant loading increases. The theory behind this direct relationship is that InfoSWMM SUSTAIN simulates contaminant reduction as a function of runoff reduction. Meaning, the more runoff the LIDI or GI is capturing, the more contaminants are eliminated. 


\subsection{Optimization Results}

The InfoSWMM SUSTAIN optimization tool run resulted in a package of 85 LIDI and GI out of the 139 total designed units. The 85 units met the optimization targets of $20 \%$ runoff reduction and $40 \%$ pollutants reduction. Results showed that the 85 units combined can achieve about $21 \%$ runoff reduction, $47 \%$ TSS reduction, $75 \%$ BOD reduction, and $60 \%$ COD reduction. The total estimated cost for this project would be $\$ 2,747,943$.

Table 4-13. Total Cost and Performance Summary of LIDI/GI

\begin{tabular}{|l|c|c|r|r|r|}
\hline Subcatch. ID & Cost & $\begin{array}{c}\text { Runoff } \\
\text { Reduction }\end{array}$ & $\begin{array}{c}\text { POLL - 1 } \\
\text { Reduction }\end{array}$ & $\begin{array}{c}\text { POLL - 2 } \\
\text { Reduction }\end{array}$ & $\begin{array}{c}\text { POLL - 3 } \\
\text { Reduction }\end{array}$ \\
\hline SUB-1 & $\$ 2747942.67$ & $20.69 \%$ & $47.18 \%$ & $75.39 \%$ & $60.05 \%$ \\
\hline
\end{tabular}

Pollutnt-1;TSS, Pollutnt-2; BOD, Pollutnt-3;COD.

It was revealed that the most cost-effective GI, specifically for North Shore neighborhood and at the specified targets, are green roofs, bioretention cells, and grassed swales. Table 4-14 below shows the chosen 85 units coupled with their costs. Porous pavement and rain barrels were eliminated. The reason behind the elimination of the porous pavement could be because of the high excavation cost of the impermeable material. Green roof cost is divided into green roof system and excavation and removal, in which the greatest share goes to the green roof system. Bioretention cost is divided between its component; excavation and removal, woody shurbs, planting media, small trees, perennials, mulch, gravel, grass, grading/finishing, and backfilling, in which the greatest share goes to excavation and removal. Grassed swale cost goes into excavation and removal, grading/finishing, and grass. 
Table 4-14. LIDI and GI costs

\begin{tabular}{|c|c|c|c|}
\hline LID ID & LID Type & $\begin{array}{c}\text { Number of } \\
\text { Units }\end{array}$ & Cost \\
\hline LID1 & 12: Green Roof & 1 & $\$ 43304.78$ \\
\hline LID2 & 12: Green Foof & 1 & $\$ 29589.96$ \\
\hline LID 3 & 12: Green Roof & 1 & $\$ 13296.38$ \\
\hline LID 4 & 12: Green Foof & 1 & $\$ 44748.07$ \\
\hline LID5 & 12: Green Roof & 1 & $\$ 68271.45$ \\
\hline LIDG & 12: Green Foof & 1 & $\$ 27646.43$ \\
\hline LID7 & 12: Green Foof & 1 & $\$ 29449.92$ \\
\hline LIDB & 12: Green Foof & 1 & $\$ 3445.35$ \\
\hline LIDG & 12: Green Roof & 1 & $\$ 54109.90$ \\
\hline LID10 & 12: Green Foof & 1 & $\$ 57964.19$ \\
\hline LID11 & 12: Green Roof & 1 & $\$ 45119.79$ \\
\hline LID12 & 12: Green Foof & 1 & $\$ 49549.94$ \\
\hline LID13 & 12: Green Roof & 1 & $\$ 10734.79$ \\
\hline LID1 4 & 12: Green Foof & 1 & $\$ 2939.40$ \\
\hline LID15 & 12: Green Roof & 1 & $\$ 17355.53$ \\
\hline LID16 & 12: Green Foof & 1 & $\$ 29292.32$ \\
\hline LID17 & 12: Green Foof & 1 & $\$ 17269.79$ \\
\hline LID18 & 12: Green Foof & 1 & $\$ 58375.17$ \\
\hline LID19 & 12: Green Foof & 1 & $\$ 54241.19$ \\
\hline LID21 & 12: Green Roof & 1 & $\$ 23013.72$ \\
\hline LID22 & 12: Green Foof & 1 & $\$ 13879.47$ \\
\hline LID23 & 12: Green Roof & 1 & $\$ 2311.98$ \\
\hline LID24 & 12: Green Foof & 1 & $\$ 32667.84$ \\
\hline LID25 & 12: Green Roof & 1 & $\$ 44015.81$ \\
\hline LID26 & 12: Green Foof & 1 & $\$ 67853.33$ \\
\hline LID 27 & 12: Green Foof & 1 & $\$ 39276.03$ \\
\hline LID29 & 12: Green Roof & 1 & $\$ 17400.72$ \\
\hline LID30 & 12: Green Foof & 1 & $\$ 32122.51$ \\
\hline LID 31 & 12: Green Foof & 1 & $\$ 21326.98$ \\
\hline LID 32 & 12: Green Foof & 1 & $\$ 83478.51$ \\
\hline LID 33 & 12: Green Foof & 1 & $\$ 6305.40$ \\
\hline LID 34 & 12: Green Foof & 1 & $\$ 81367.13$ \\
\hline LID 35 & 12: Green Foof & 1 & $\$ 17902.78$ \\
\hline LID36 & 12: Green Foof & 1 & $\$ 4703.04$ \\
\hline LID 37 & 12: Green Foof & 1 & $\$ 54629.92$ \\
\hline LID 38 & 12: Green Foof & 1 & $\$ 15348.87$ \\
\hline LID 39 & 12: Green Foof & 1 & $\$ 30141.31$ \\
\hline LID 40 & 12: Green Foof & 1 & $\$ 29308.30$ \\
\hline LID 41 & 12: Green Foof & 1 & $\$ 64861.46$ \\
\hline LID 42 & 12: Green Foof & 1 & $\$ 22731.36$ \\
\hline LID 43 & 12: Green Foof & 1 & $\$ 12105.96$ \\
\hline LID 44 & 12: Green Foof & 1 & $\$ 7556.23$ \\
\hline LID 45 & 12: Green Foof & 1 & $\$ 52233.12$ \\
\hline LID 46 & 12: Green Foof & 1 & $\$ 16709.49$ \\
\hline LID 47 & 12: Green Foof & 1 & $\$ 60717.11$ \\
\hline LID 48 & 12: Green Foof & 1 & $\$ 165765.83$ \\
\hline LID51 & 12: Green Roof & 1 & $\$ 6506.03$ \\
\hline
\end{tabular}




\begin{tabular}{|c|c|c|c|}
\hline LID 52 & 12: Green Roof & 1 & $\$ 31066.84$ \\
\hline LID 53 & 12: Green Foof & 1 & $\$ 47978.00$ \\
\hline LID 54 & 12: Green Roof & 1 & $\$ 28365.60$ \\
\hline LID55 & 12: Green Roof & 1 & $\$ 29678.62$ \\
\hline LID56 & 12: Green Foof & 1 & $\$ 37999.91$ \\
\hline LID 57 & 12: Green Roof & 1 & $\$ 42768.27$ \\
\hline LID 58 & 12: Green Roof & 1 & $\$ 2543.88$ \\
\hline LID59 & 12: Green Foof & 1 & $\$ 17103.67$ \\
\hline LIDGO & 12: Green Foof & 1 & $\$ 34585.96$ \\
\hline LIDG1 & 12: Green Roof & 1 & $\$ 42536.95$ \\
\hline LIDG2 & 12: Green Roof & 1 & $\$ 3715.67$ \\
\hline LIDG3 & 12: Green Roof & 1 & $\$ 70708.68$ \\
\hline LIDG4 & 12: Green Foof & 1 & $\$ 76182.38$ \\
\hline LIDG5 & 12: Green Roof & 1 & $\$ 29606.29$ \\
\hline LIDGE & 12: Green Foof & 1 & $\$ 35072.64$ \\
\hline LIDE7 & 12: Green Foof & 1 & $\$ 20120.18$ \\
\hline LIDGB & 12: Green Roof & 1 & $\$ 12599.72$ \\
\hline LID 79 & 2: Bio-Petention & 1 & $\$ 8540.71$ \\
\hline LIDBO & 2: Bio-Petention & 1 & $\$ 18305.27$ \\
\hline LID81 & 2: Bio-Petention & 1 & $\$ 15492.26$ \\
\hline LIDB2 & 2: Bio-Petention & 1 & $\$ 21785.13$ \\
\hline LIDB4 & 8: Grassed Swale & 1 & $\$ 684.75$ \\
\hline LIDB5 & 8: Girassed Swale & 1 & $\$ 5081.26$ \\
\hline LIDBG & 8: Grassed Swale & 1 & $\$ 4133.90$ \\
\hline LIDB7 & 8: Girassed Swale & 1 & $\$ 2262.06$ \\
\hline LIDBg & 8: Grassed Swale & 1 & $\$ 2569.13$ \\
\hline LIDBS & 8: Girassed Swale & 1 & $\$ 8432.88$ \\
\hline LIDGO & 8: Grassed Swale & 1 & $\$ 2401.70$ \\
\hline LIDG2 & 8: Grassed Swale & 1 & $\$ 7171.51$ \\
\hline LIDG3 & 8: Grassed Swale & 1 & $\$ 3385.20$ \\
\hline LIDG4 & 8: Grassed Swale & 1 & $\$ 2537.98$ \\
\hline LID95 & 8: Grassed Swale & 1 & $\$ 744.07$ \\
\hline LIDG7 & 8: Grassed Swale & 1 & $\$ 498.50$ \\
\hline LIDGB & 8: Grassed Swale & 1 & $\$ 2741.66$ \\
\hline LIDG9 & 8: Grassed Swale & 1 & $\$ 1950.68$ \\
\hline LID100 & 8: Grassed Swale & 1 & $\$ 1808.83$ \\
\hline LID101 & 8: Girassed Swale & 1 & $\$ 4060.29$ \\
\hline LID102 & 8: Grassed Swale & 1 & $\$ 4015.30$ \\
\hline LID103 & 8: Grassed Swale & 1 & $\$ 694.13$ \\
\hline
\end{tabular}




\subsection{EPA SWMM 5.1 Modeling Results of Indian Creek Drive Location}

Designing LIDI and GI to control runoff for the Indian Creek Drive location was very challenging because runoff resulting from sea level rise is harder to control compared to long duration storm events. Given the surface area of the cross section, one control unit was not enough to control water levels elevated from the creek. Therefore, a dual BMP system of an infiltration trench and a bioretention cell was investigated. Results showed that the designed combined system successfully controlled flooding resulting from king tide effect.

Table 4-15. Dual BMP System Effectiveness in Controlling King Tide Flooding Before

\begin{tabular}{l|c|c|c|c|c|c|c|c|}
\hline & $\begin{array}{c}\text { Total } \\
\text { Precip } \\
\text { in }\end{array}$ & $\begin{array}{c}\text { Total } \\
\text { Runon } \\
\text { in }\end{array}$ & $\begin{array}{c}\text { Total } \\
\text { Evap } \\
\text { in }\end{array}$ & $\begin{array}{c}\text { Total } \\
\text { Infil } \\
\text { in }\end{array}$ & $\begin{array}{c}\text { Total } \\
\text { Runoff } \\
\text { in }\end{array}$ & $\begin{array}{c}\text { Total } \\
\text { Runoff } \\
10^{\wedge} 6 \text { gal }\end{array}$ & $\begin{array}{c}\text { Peak } \\
\text { Runoff } \\
\text { CFS }\end{array}$ & $\begin{array}{c}\text { Runoff } \\
\text { Coeff }\end{array}$ \\
\hline S1 & 27.60 & \multicolumn{2}{c|}{0.00} & 0.00 & 0.00 & 27.55 & 0.07 & 1.25 \\
\hline
\end{tabular}

After

\begin{tabular}{|c|c|c|c|c|c|c|c|c|}
\hline Subcatchment & LID Control & $\begin{array}{l}\text { Total } \\
\text { Inflow } \\
\text { in }\end{array}$ & $\begin{array}{l}\text { Evap } \\
\text { Loss } \\
\text { in }\end{array}$ & $\begin{array}{l}\text { Infil } \\
\text { Loss } \\
\text { in }\end{array}$ & $\begin{array}{c}\text { Surface } \\
\text { Outflow } \\
\text { in }\end{array}$ & $\begin{array}{c}\text { Drain } \\
\text { Outflow } \\
\text { in }\end{array}$ & $\begin{array}{c}\text { Initial } \\
\text { Storage } \\
\text { in }\end{array}$ & $\begin{array}{c}\text { Final } \\
\text { Storage } \\
\text { in }\end{array}$ \\
\hline S1 & Bio-Retention-Cell & 27.60 & 0.00 & 0.00 & 16.87 & 0.00 & 0.75 & 11.48 \\
\hline S2 & Infiltration-Trench & 18.75 & 0.00 & 18.75 & 0.00 & 0.00 & 0.00 & 0.00 \\
\hline
\end{tabular}

The mechanism of this design is such that when the creek water level starts elevating water enters the bioretention cell, which will delay runoff until storage reaches maximum capacity and hits the drain. At this point, any excess water accumulated in the bioretention storage above the drain gets diverted to the infiltration trench which is designed above a bed of soil where water could easily infiltrate. Given the very high permeability of the gravel bed of the infiltration trench this will cause a smooth flood free groundwater recharge. The proposed solution is a 2.6 feet bioretention cell composed of 
10-inch PEA gravel layer, 16-inch loamy sand filter media, and perennial garden at the top adjacent to a 2-feet infiltration trench made from a mixture of gravel and crushed stone. Figure 4-13 shows the dual design specification and clarifies its mechanism.

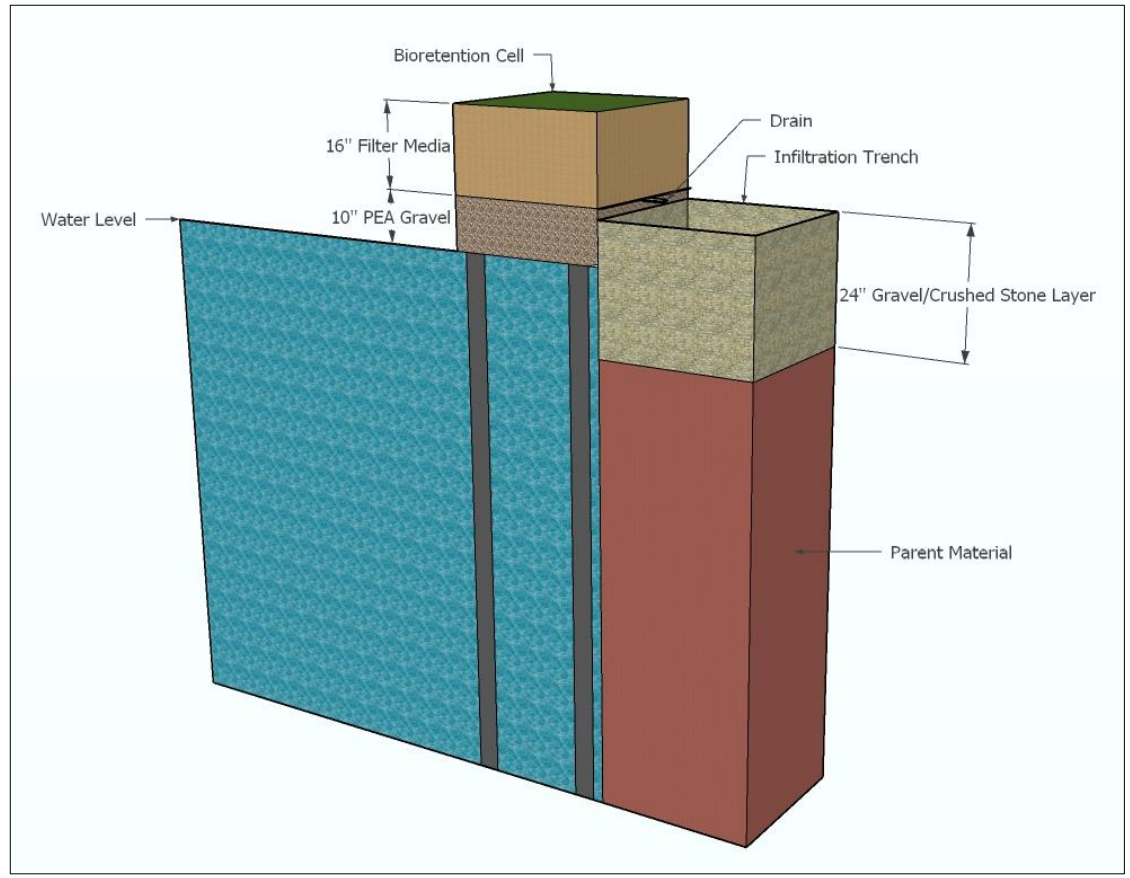

Figure 4-13. Indian Creek Drive Dual BMP Proposed Solution 


\section{CONCLUSIONS, ASSUMPTIONS AND LIMITATIONS, AND RECOMMENDATIONS}

\subsection{Conclusions}

The CMB has been struggling with serious flooding resulting from heavy rainfall events and sea level rise over the past decade. The natural low-lying and flat topography of the city, and considerable urbanization have significantly accelerated the effects of climate change. Worldwide, glaciers are melting, sea level is rising, and storms are intensifying in a rapid pattern. Mitigation is important, but adaptation has become a necessity. This research investigated the effectiveness of LIDI and GI in controlling and reducing flooding resulting from heavy rainfall events and sea-level rise, and in improving stormwater quality in the CMB.

The central hypothesis of this research was that "the designed LIDI and GI designs will control and reduce the frequent flood events in the CMB resulting from heavy rainfall events and sea-level rise, and improve stormwater quality by reducing significant amounts of TSS, BOD, and COD loadings." Within the limitation of the model, math and computation herein used, the modeling results prove the central hypothesis of this research. In addition, the three research objectives were met resulting in:

1. Establishing a comprehensive plan of suitable sites for placing LIDI and GI according to suitability criteria for the CMB.

2. Testing designs of LIDI and GI solutions that will control and reduce flooding as a result of heavy rainfall events and sea level rise in the CMB. 
3. Testing the effects of the same LIDI and GI designs on the improvement of water quality of flowing waters.

Results showed that green roof is the most suitable type of LIDI and GI to be implemented in the CMB, given the heavily urbanized state of the city. In addition, it was evident that LIDI and GI are most effective in controlling low-intensity long-duration storm events compared to high-intensity long-duration ones. Runoff resulting from sea level rise, such as the king tide effect phenomena, is harder to control because sea level elevates rapidly resulting in massive runoff in a brief period. However, understanding the multiple engineered layers of each type of LIDI and GI and how water molecules behave the moment they hit the LIDI and GI surface until they reach storage or infiltrate to groundwater is an important skill needed to produce solutions that will reduce or eliminate flooding resulting from sea level rise.

\subsection{Assumptions and Limitations}

The meteorological data used in the model were average monthly rates for the month of April of 2018. Both EPA SWMM 5.1 and InfoSWMM by Innovyze are limited in simulating water quality with a buildup of loadings of constituents below 0.001 lb/acre. For land uses with lower than average contaminants loading, such as low-density residential, buildup simulation for most contaminants was not possible. In addition, pollutants removal efficiencies were a function of runoff reduction rather than the removal efficiency of the BMP itself. The InfoSWMM SUSTAIN optimization tool cost manager lacks customization. For example, for the calculated cost for a bioretention cell and grassed swale, cost breakdown included soil cost. The CMB soil type is A and the chosen soil type for the design of bioretention cells and grassed swales is type A as well. 
Therefore, $88 \%$ of the soil that will be excavated from the ground will then be added back in the soil layer of the implemented unit, yet the cost of it is not subtracted from the overall cost of the designed unit. However, in this example soil cost is a small fraction of the entire budget and will not result in a major decision change.

\subsection{Recommendations}

This study investigated the quantity and quality aspects of runoff using the hydrologic-hydraulic computational model SWMM (i.e., two versions, those of USEPA and Innovyze) in order to assess the potential effectiveness of LIDI and GI solutions and designs. The investigation used a number of solutions and designs that were then characterized and evaluated by comparing the level of flooding reduction and increase in water quality for both pre-development and post-development conditions. The expectation was to determine the potential effectiveness rather than optimizing the type of solutions either by their operational performance or cost effectiveness for the unique characteristics of the $\mathrm{CMB}$, which was the case study. Of course, this study also illustrated with much detail the way to do cost optimization for the solutions that were evaluated. As a result, practitioners must understand that although the potential effectiveness has been herein demonstrated, within the scope of this study, any selection of technologies for the purpose of final deployment and operation in a specific urban community, including the CMB, should be based on the goals of the control program of that community.

In addition, it is recommended that any study should be as comprehensive as possible in the screening and selection of LIDI and GI solutions and designs, covering most appropriate scenarios of performance, with optimization of either operational 
performance or cost or both. It is also recommended that an assessment should considered both the local characteristics and needs of any particular site within a community, but the effects at the level of the whole community and its surrounding environments as well. In reference to the use of models to develop, for instance hydrologic scenarios and designs of solutions, it is important to also evaluate uncertainty of any results by conducting most appropriate sensitivity analyses of any results in support of final decision-making.

This study should be most helpful to the CMB to support its management of flooding under any adaptation scenarios that may possibly resolve from climate changes. Flooding could be again caused as a result of changes in inland flooding from precipitation patterns or from sea-level rise or both. 


\section{REFERENCES}

[1] S. Prasad, "Assessing the need for evacuation assistance in the 100 year floodplain of South Florida," Applied Geography, vol. 67, pp. 67-76, 2016.

[2] J. Czajkowski, K. Simmons, and D. Sutter, "An analysis of coastal and inland fatalities in landfalling US hurricanes," Natural Hazards, vol. 59, no. 3, pp. 15131531, 2011.

[3] "Southeast Florida regional climate change compact sea level rise work group (compact)," Unified Sea Level Rise Projection for Southeast Florida, 2015.

[4] J. Walsh, D. Wuebbles, K. Hayhoe, J. Kossin, K. Kunkel, G. Stephens, P. Thorne, R. Vose, M. Wehner, J. Willis, D. Anderson, S. Doney, R. Feely, P. Hennon, V. Kharin, T. Knutson, F. Landerer, T. Lenton, J. Kennedy, and R. Somerville, "Our changing climate," Climate Change Impacts in the United States: the Third National Climate Assessment, pp. 19-67, 2014.

[5] "Flood zone maps," The Federal Emergency Management Agency, 2017, Available: http://www.miamidade.gov/environment/flood-maps.asp

[6] "Landsat imagery," USGS Earth Explorer, 2018, Available: https://earthexplorer.usgs.gov/

[7] M. Giacomoni and J. Joseph, "Multi-objective evolutionary optimization and Monte Carlo simulation for placement of low impact development in the catchment scale," Journal of Water Resources Planning and Management, vol. 143, no. 9, 2017.

[8] P. Egodawatta, E. Thomas, and A. Goonetilleke, "Mathematical interpretation of pollutant wash-off from urban road surfaces using simulated rainfall," Water Research, vol. 41, no. 13, pp. 3025-3031, 2007.

[9] "2000 national water quality inventory," Document EPA-841-R-02-001, 2002.

[10] D. Jurries, "Bioswales, vegetative buffers, \& constructed wetlands for storm water discharge pollution removal," Document 2003.

[11] K. Hill, "Coastal infrastructure: a typology for the next century of adaptation to sea-level rise," Frontiers in Ecology and the Environment, vol. 13, no. 9, pp. 468476, 2015.

[12] "City of Miami Beach, FL," Google Maps, 2018, Available: https://www.google.com/maps/search/Indian+Creek+Drive,+Miami+Beach,+FL/ @ 25.8038511,-80.1271648,360m/data=!3m1!1e3 
[13] T. Fry and R. Maxwell, "Evaluation of distributed BMPs in an urban watershedHigh resolution modeling for stormwater management," Hydrological Processes, vol. 31, no. 15, pp. 2700-2712, 2017.

[14] E. Bean, W. Hunt, and D. Bidelspach, "Field survey of permeable pavement surface infiltration rates," Journal of Irrigation and Drainage Engineering, vol. 133, no. 3, pp. 249-255, 2007.

[15] E. Fassman and S. Blackbourn, "Urban runoff mitigation by a permeable pavement system," Journal of Hydrologic Engineering, vol. 15, no. 6, pp. 475$485,2010$.

[16] C. Arnold and J. Gibbons, "Impervious surface coverage: the emergence of a key environmental indicator," Journal of the American Planning Association, vol. 62, no. 2 , pp. 243-258, 1996.

[17] G. Krebs, T. Kokkonen, M. Valtanen, H. Koivusalo, and H. Setälä, "A high resolution application of a stormwater management model (SWMM) using genetic parameter optimization," Urban Water Journal, vol. 10, no. 6, pp. 394410, 2013.

[18] J. Wang, W. Che, W. Zhang, J. Li, and H. Yi, "Roadside stormwater master plan using low impact development," in Low Impact Development: Redefining Water in the City, S. Struck, Ed.: ASCE, 2010, pp. 312-322.

[19] B. Anderson, B. Phillips, J. Voorhees, K. Siegler, and R. Tjeerdema, "Bioswales reduce contaminants associated with toxicity in urban storm water," Environmental Toxicology Chemistry, vol. 35, no. 12, pp. 3124-3134, 2016.

[20] M. Francey, T. Fletcher, A. Deletic, and H. Duncan, "New insights into the quality of urban storm water in south eastern Australia," Journal of Environmental Engineering vol. 136, no. 4, pp. 381-390, 2010.

[21] A. Maestre and R. Pitt, "National stormwater quality database version 1.1," Database 2005.

[22] C. Martin-Mikle, K. de Beurs, J. Julian, and P. Mayer, "Identifying priority sites for low impact development (LID) in a mixed-use watershed," Landscape and Urban Planning, vol. 140, pp. 29-41, 2015.

[23] N. Chang, J. Lu, T. Chui, and N. Hartshorn, "Global policy analysis of low impact development for stormwater management in urban regions," Land Use Policy, vol. 70, pp. 368-383, 2018. 
[24] H. Pochee and I. Johnston, "Understanding design scales for a range of potential green infrastructure benefits in a London Garden City," Building Services Engineering Research and Technology, vol. 38, no. 6, pp. 728-756, 2017.

[25] H. Taha, G. Akbar, and A. Rosenfield, "A vegetation canopy micro climate a field project in Davis," Lawerence Berkeley Laboratory, Document 24593, 1988.

[26] J. Merriam, "Low-impact development comes to Florida," Florida Watershed, vol. 4, no. 1, pp. 1-6, 2011.

[27] J. Gregory, B. Cunningham, L. Ammeson, M. Clard, and H. Hall, "Modifying low-impact development practices for Florida watersheds," Florida Watershed, vol. 4, no. 1, pp. 7-11, 2011.

[28] J. Steffen, M. Jensen, C. Pomeroy, and S. Burian, "Water supply and stormwater management benefits of residential rainwater harvesting in U.S. cities," Journal of the American Water Resources Association, vol. 49, no. 4, pp. 810-824, 2013.

[29] "Managing stormwater with low impact development practices addressing barriers to LID," Report EPA 901-F-09-003, 2009.

[30] "Lamb drove sustainable drainage system monitoring project," Report 9S7422, 2012.

[31] Z. Zahmatkesh, S. Burian, M. Karamouz, H. Tavakol-Davani, and E. Goharian, "Low-impact development practices to mitigate climate change effects on urban stormwater runoff: case study of New York City," Journal of Irrigation and Drainage Engineering, vol. 141, no. 1, 2015.

[32] I. Alyaseri and J. Zhou, "Stormwater volume reduction in combined sewer using permeable pavement: city of St. Louis," Journal of Environmental Engineering, vol. 142, no. 4, 2016.

[33] J. Lee, M. Borst, R. Brown, L. Rossman, and M. Simon, "Modeling the hydrologic processes of a permeable pavement system," Journal of Hydrologic Engineering, vol. 20, no. 5, 2015.

[34] M. Shafique, D. Lee, and R. Kim, "A field study to evaluate runoff quantity from blue roof and green blue roof in an urban area," International Journal of Control and Automation, vol. 9, no. 8, pp. 59-68, 2016.

[35] M. Niazi et al., "Storm water management model: performance review and gap analysis," Journal of Sustainable Water in the Built Environment, vol. 3, no. 2, 2017. 
[36] "InfoSWMM student analysis and design workbook," User Manual 2015.

[37] Innovyze, "Sustainable urban stormwater best management practices with InfoSWMM Sustain plus InfoSWMM 2D and SWMMLive," ed, 2015.

[38] L. Rossman, "Storm Water Management Model User's Manual Version 5.1," User manual EPA/600/R-14/413b, 2015.

[39] A. Massoudieh et al., "A flexible modeling framework for hydraulic and water quality performance assessment of stormwater green infrastructure," Environmental Modelling \& Software, vol. 92, pp. 57-73, 2017.

[40] X. Jin, "Raster GIS data models," ed, 2017.

[41] "BMP siting tool step-by-step guide," Tatera Tech, Inc., Report 2013.

[42] D. Chin and R. Patterson, "Quantification of hydrological processes and assessment of rainfall-runoff models in miami-dade county, Florida," in "U.S. Geological Survey Scientific Invistigations Report 2004-5191," 2005.

[43] "Drainage manual - IDF curves and rainfall distribution," Florida Department of Trasnportations 2015, Available: http://www.fdot.gov/roadway/Drainage/Manualsandhandbooks.shtm

[44] "Florida neighborhood boundaries," Zillow Shapefiles, 2018 Available: https://www.zillow.com/howto/api/neighborhood-boundaries.htm

[45] "Urban hydrology for small watersheds," Report 210-VI-TR-55, 1986.

[46] M. Clar, B. Barfield, and T. O'Connor, "Stormwater best management practice deisgn guide: volume 2 vegetative biofilters," Environmental Protection Agency, vol. EPA/600/R-04/184, 2004.

[47] S. Muthukrishnan, B. Madge, A. Selvakumar, R. Field, and D. Sullivan, "The use of best management practices (BMPs) in urban watersheds," Environmental Protection Agency, vol. EPA/600/R-04/184, 2004.

[48] R. Dickinson, "How to Use EPA SWMM 5 Water Quality Washoff and Buildup Features," ed, 2017.

[49] "Bioretention," Virginia Water Resources Research Center, 2011, Available: https://www.vwrrc.vt.edu/swc/NonPBMPSpecsMarch11/VASWMBMPSpec9BI ORETENTION.html 
[50] "Permeable pavement," Virginia Water Resources Research Center, 2011, Available: https://www.vwrrc.vt.edu/swc/NonPBMPSpecsMarch11/VASWMBMPSpec7PE RMEABLEPAVEMENT.html

[51] "Current conditions for Florida: groundwater," United State Geological Survey, 2018, Available:

https://waterdata.usgs.gov/fl/nwis/current/?type=gw\&group_key=county_cd

[52] "Reducing urban heat islands: compendium of strategies," U.S. Environmnetal Protection Agency 2008, Available: https://www.epa.gov/heat-islands/heat-islandcompendium

[53] "Permanent BMP standared details," Southeast Metro Stormwater Authority, 2009, Available: http://www.semswa.org/permanent-bmp-standard-details.aspx

[54] "Rain barrels," Tip of the Mitt Watershed Council, 2018, Available: https://www.watershedcouncil.org/rain-barrels.html

[55] "Rain barrel information "Sand Diego Departments of Public Works 2013, Available:

https://www.sandiegocounty.gov/content/sdc/dpw/watersheds/residential/RainBar relInformation.html 
APPENDICES 


\section{APPENDIX A}

\section{Hydrological Data}

Figure 1-A. Miami-Dade County IDF Curve ....................................................... 82

Figure 2-A. Miami-Dade County Monthly Saturated-Zone Evaporation Rate for Selected Wells and the Potential Evaporation Rate $\left(E_{o}\right)$ at the Ground Surface ......... 83

Figure 3-A. Miami Beach Groundwater Table Depth …........................................ 83

Table 1-A. Runoff Curve Number for Urban Areas ................................................... 84

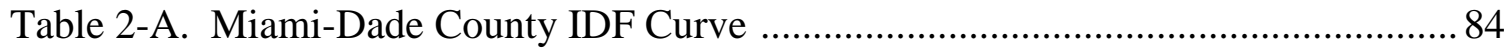




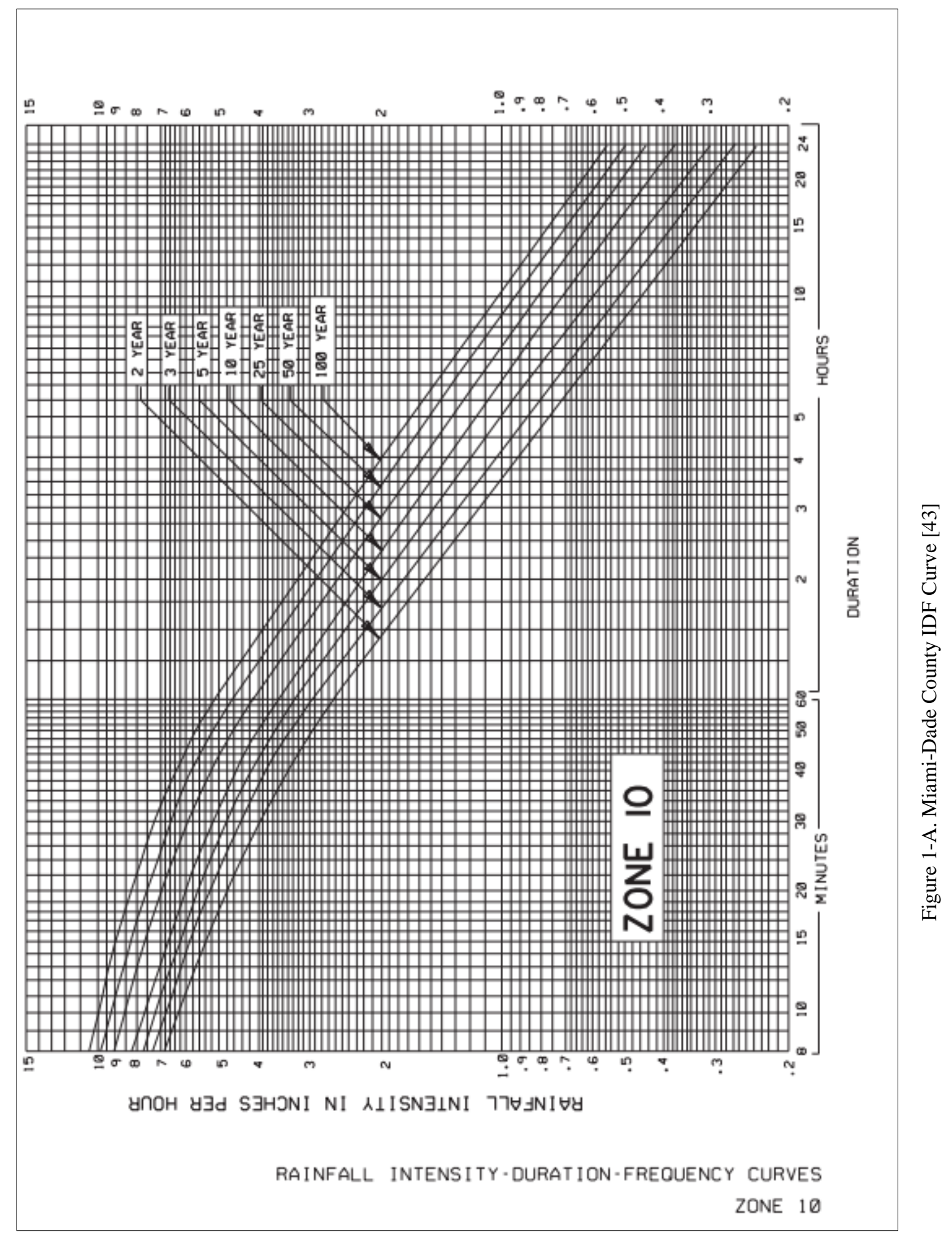




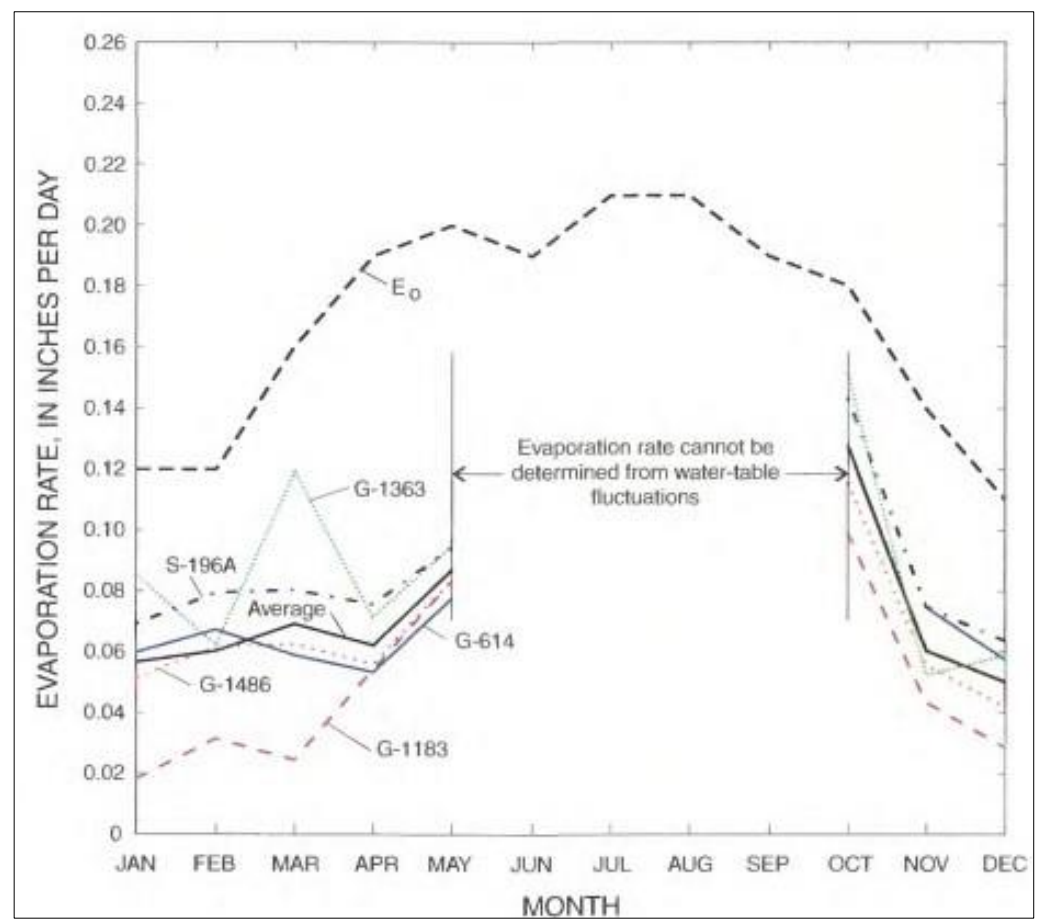

Figure 2-A. Monthly Saturated-Zone Evaporation Rate for Selected Wells and the Potential Evaporation Rate $\left(E_{o}\right)$ at the Ground Surface [42]

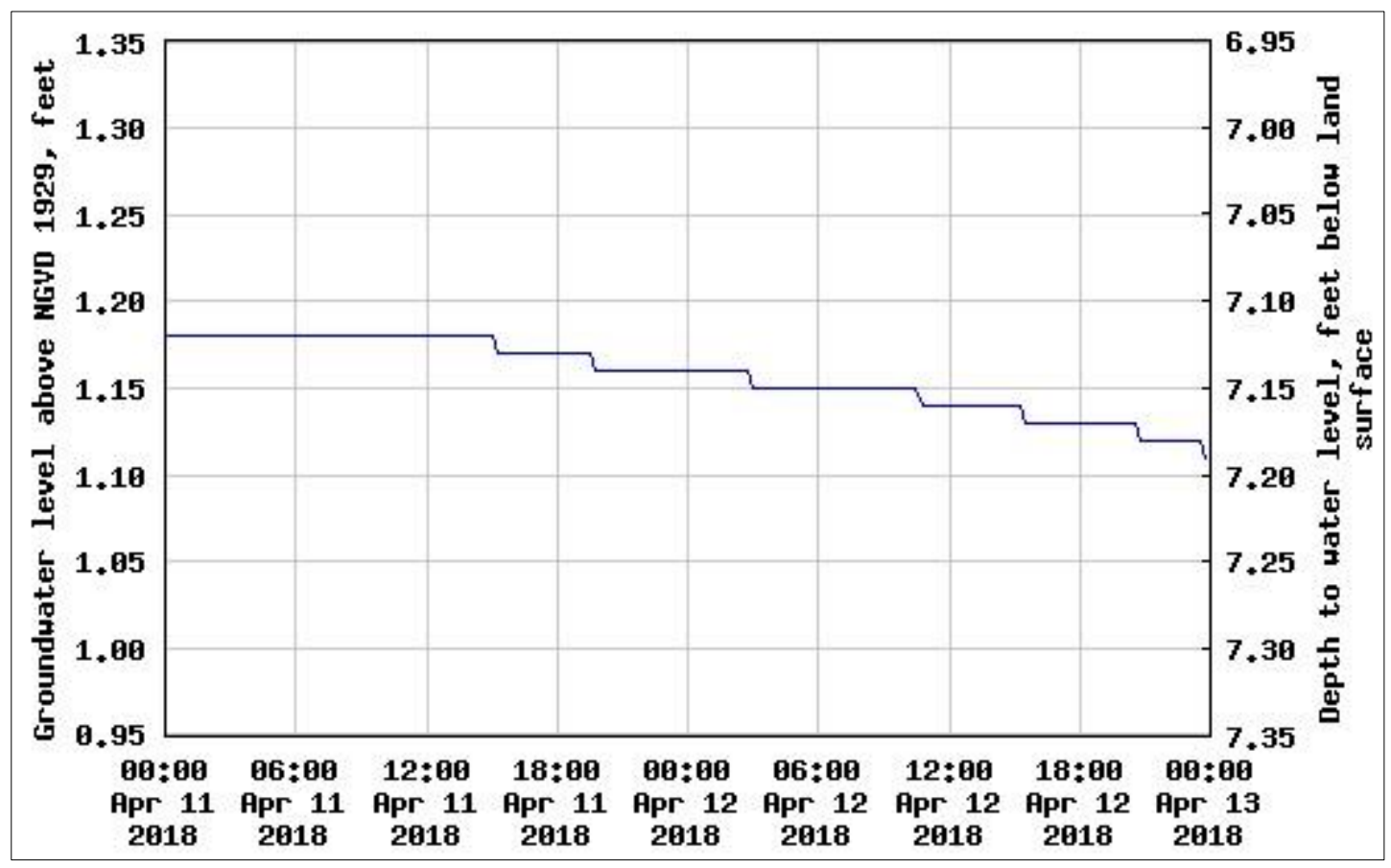

Figure 3-A. Miami Beach Groundwater Table (NGVD, feet) [51] 
Table 1-A. Runoff Curve Numbers for Urban Areas [45]

\begin{tabular}{|c|c|c|c|c|c|}
\hline \multirow[b]{2}{*}{ Cover type and hydrologic condition } & \multirow[b]{2}{*}{$\begin{array}{l}\text { Average percent } \\
\text { impervious area } z\end{array}$} & \multicolumn{4}{|c|}{$\begin{array}{r}\text { Curve numbers for } \\
\text {-hydrologic soil group }\end{array}$} \\
\hline & & A & B & C & D \\
\hline \multicolumn{6}{|l|}{ Fully developed urban areas (vegetation established) } \\
\hline \multicolumn{6}{|l|}{ Open space (lawns, parks, golf courses, cemeteries, etc.) 3 : } \\
\hline Poor condition (grass cover $<50 \%$ ) & & 68 & 79 & 86 & 89 \\
\hline 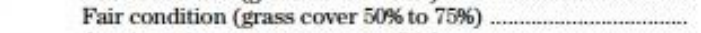 & & 49 & 69 & 79 & 84 \\
\hline Good condition (grass cover $>75 \%$ ) & & 39 & 61 & 74 & 80 \\
\hline \multicolumn{6}{|l|}{ Impervious areas: } \\
\hline $\begin{array}{l}\text { Paved parking lots, roofs, driveways, etc. } \\
\text { (excluding right-of-way) }\end{array}$ & & 98 & 98 & 98 & 98 \\
\hline \multicolumn{6}{|l|}{ Streets and roads: } \\
\hline right-of-way) & & 98 & 98 & 98 & 98 \\
\hline Paved; open ditches (including right-of-way) ......................... & & 83 & 89 & 92 & 93 \\
\hline 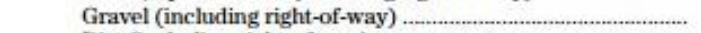 & & 76 & 85 & 89 & 91 \\
\hline 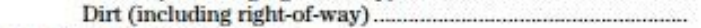 & & 72 & 82 & 87 & 89 \\
\hline \multicolumn{6}{|l|}{ Western desert urban areas: } \\
\hline Natural desert landscaping (pervious areas only) $y$................... & & 63 & 77 & 85 & 88 \\
\hline \multicolumn{6}{|l|}{$\begin{array}{l}\text { Artificial desert landscaping (impervious weed barrier, } \\
\text { desert shrub with } 1 \text { - to } 2 \text {-inch sand or gravel mulch }\end{array}$} \\
\hline and basin borders) & & 96 & 96 & 96 & 96 \\
\hline \multicolumn{6}{|l|}{ Urban districts: } \\
\hline Commercial and business ...................... & 85 & 89 & 92 & 94 & 95 \\
\hline Industrial ... & 72 & 81 & 88 & 91 & 93 \\
\hline \multicolumn{6}{|l|}{ Residential districts by average lot size: } \\
\hline $1 / 8$ acre or less (town houses) ............ & 65 & 77 & 85 & 90 & 92 \\
\hline $1 / 4$ acre & 38 & 61 & 75 & 83 & 87 \\
\hline $1 / 3$ acre & 30 & 57 & 72 & 81 & 86 \\
\hline $1 / 2$ acre & 25 & 54 & 70 & 80 & 85 \\
\hline 1 acre & 20 & 51 & 68 & 79 & 84 \\
\hline 2 acres & 12 & 46 & 65 & 77 & 82 \\
\hline \multicolumn{6}{|l|}{ Developing urban areas } \\
\hline Newly graded areas & & & & & \\
\hline (pervious areas only, no vegetation) & & 77 & 86 & 91 & 94 \\
\hline
\end{tabular}

Table 2-A. Miami-Dade County Meteorological Characteristics [42]

\begin{tabular}{|lccc|}
\hline Month & $\begin{array}{c}\text { Average } \\
\text { temperature } \\
\text { (degrees } \\
\text { Fahrenheit) }\end{array}$ & $\begin{array}{c}\text { Average } \\
\text { rainfall } \\
\text { (inches) }\end{array}$ & $\begin{array}{c}\text { Maximum } \\
\text { evapotrans- } \\
\text { piration } \\
\text { (inches } \\
\text { per day) }\end{array}$ \\
\hline January & 67.1 & 2.1 & 0.12 \\
February & 67.8 & 2.0 & .12 \\
March & 71.7 & 1.9 & .16 \\
April & 75.3 & 3.1 & .19 \\
May & 78.5 & 6.5 & .20 \\
June & 81.0 & 9.1 & .19 \\
July & 82.4 & 6.0 & .21 \\
August & 82.8 & 7.0 & .19 \\
September & 81.8 & 8.1 & .19 \\
Octoher & 77.9 & 7.1 & .19 \\
November & 72.8 & 2.7 & .19 \\
December & 68.5 & 1.9 & .19 \\
\hline
\end{tabular}




\section{APPENDIX B}

\section{GIS Attribute Tables}

\&

\section{North Shore Neighborhood Siting Manager Results}

TABLE / FIGURE PAGE

Table 1-B. Urban Land Use Attribute Table .............................................................. 86

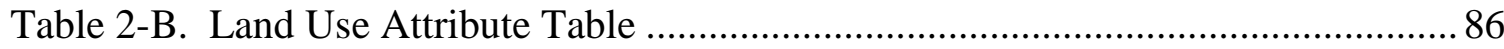

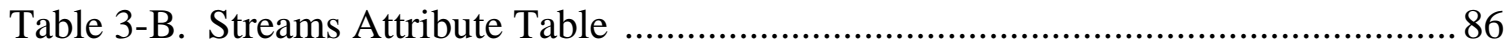

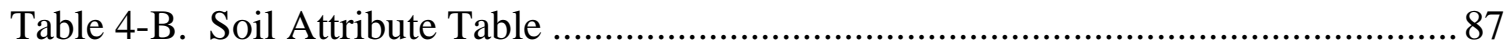

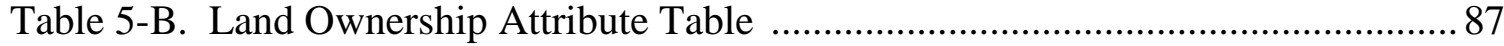

Table 6-B. Percent Impervious Attribute Table......................................................... 88

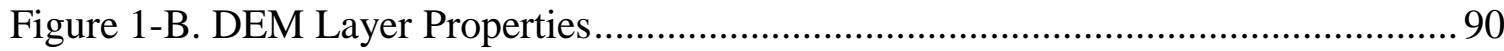

Table 7-B. North Shore LIDI and GI Unit Area and Top Width................................. 91 
Table 1-B. Urban Land Use Attribute Table

\begin{tabular}{|r|r|l|l|}
\hline & FID & Shape * & \\
\hline 0 & Polygon & \\
\hline 1 & Polygon & Airports/Ports \\
\hline 2 & Polygon & Communications, Utilities, Terminals, Plants \\
\hline 3 & Polygon & Industrial \\
\hline 4 & Polygon & Institutional \\
\hline 5 & Polygon & Low-Density Multi-Family \\
\hline 6 & Polygon & Multi-Family, Migrant Camps \\
\hline 7 & Polygon & Office \\
\hline 8 & Polygon & Parks (Including Preserves \& Conservation) \\
\hline 9 & Polygon & Shopping Centers, Commercial, Stadiums, Tracks \\
\hline 10 & Polygon & Single-Family \\
\hline 11 & Polygon & Streets/Roads, Expressways, Ramps \\
\hline 12 & Polygon & Streets/Roads/Canals RW \\
\hline 13 & Polygon & Townhouses \\
\hline 14 & Polygon & Transient-Residential (Hotels/Motels) \\
\hline 15 & Polygon & Two-Family (Duplexes) \\
\hline 16 & Polygon & Vacant Unprotected \\
\hline 17 & Polygon & Vacant, Government Owned \\
\hline 18 & Polygon & Water \\
\hline
\end{tabular}

Table 2-B. Land Use Attribute Table

\begin{tabular}{|r|r|l|l|}
\hline & FID & \multicolumn{1}{|c|}{ Shape * } & \multicolumn{2}{|c|}{ LEVEL2 } \\
\hline 0 & 0 & Polygon & BAYS AND ESTUARIES \\
\hline 1 & Polygon & COMMERCIAL AND SERVICES \\
\hline & 2 & Polygon & HERBACEOUS (DRY PRAIRIE) \\
\hline & 3 & Polygon & INSTITUTIONAL \\
\hline 4 & Polygon & MAJOR BODIES OF WATER \\
\hline 5 & Polygon & MIXED RANGELAND \\
\hline 6 & Polygon & OPEN LAND \\
\hline 7 & Polygon & RECREATIONAL \\
\hline 8 & Polygon & RESERVOIRS \\
\hline 9 & Polygon & RESIDENTTAL, HIGH DENSTY \\
\hline 10 & Polygon & RESIDENTTAL, LOW DENSTY \\
\hline 11 & Polygon & RESIDENTTAL, MEDIUM DENSTY \\
\hline 12 & Polygon & STREAMS AND WATERWAYS \\
\hline 13 & Polygon & TRANSPORTATION \\
\hline 14 & Polygon & UPLAND SHRUB AND BRUSHLAND \\
\hline 15 & Polygon & UTILTIES \\
\hline
\end{tabular}

Table 3-B. Streams Attribute Table

\begin{tabular}{|r|r|c|r|r|r|r|r|r|r|}
\hline & FID & Shape $^{*}$ & OBJECTID & MAJOR1 & MINOR1 & MAJOR2 & MINOR2 & MAJOR3 & MINOR3 \\
\hline & 0 & Polyline & 141 & 50 & 412 & -99999 & -99999 & 0 & 0 \\
\hline & 1 & Polyline & 157 & 50 & 412 & -99999 & -99999 & 0 & 0 \\
\hline
\end{tabular}


Table 4-B. Soil Attribute Table

\begin{tabular}{|c|c|c|c|c|c|c|c|}
\hline & FID & Shape * & AREA & PERIMETER & MDADE_SOIL & SOIL & NAME \\
\hline 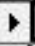 & 0 & Polygon & 2990050000 & 955221 & 2 & Water & Not specified \\
\hline & 1 & Polygon & 4223830 & 37115.2 & 168 & $\mathrm{Ca}$ & Coastal beach \\
\hline & 2 & Polygon & 2348270 & 13450.6 & 169 & $\mathrm{Ma}$ & Made land \\
\hline & 3 & Polygon & 1124290 & 4312.49 & 202 & $\mathrm{Ma}$ & Made land \\
\hline & 4 & Polygon & 422428 & 3138.45 & 209 & $\mathrm{Ma}$ & Made land \\
\hline & 5 & Polygon & 51444.7 & 1019.17 & 213 & $\mathrm{Ma}$ & Made land \\
\hline & 6 & Polygon & 331756 & 2982.61 & 223 & $\mathrm{Ma}$ & Made land \\
\hline & 7 & Polygon & 143828 & 2994.38 & 230 & $\mathrm{Ma}$ & Made land \\
\hline & 8 & Polygon & 16964.6 & 538.694 & 231 & $\mathrm{Ma}$ & Made land \\
\hline & 9 & Polygon & 166322 & 2987.7 & 232 & $\mathrm{Ma}$ & Made land \\
\hline & 10 & Polygon & 934577 & 4268.21 & 235 & $\mathrm{Ma}$ & Made land \\
\hline & 11 & Polygon & 72446.9 & 1165.83 & 239 & $\mathrm{Ma}$ & Made land \\
\hline & 12 & Polygon & 993561 & 4770.76 & 244 & $\mathrm{Ma}$ & Made land \\
\hline & 13 & Polygon & 136206 & 1991.18 & 261 & $\mathrm{Ma}$ & Made land \\
\hline & 14 & Polygon & 221479 & 1809.07 & 262 & $\mathrm{Ma}$ & Made land \\
\hline & 15 & Polygon & 64912.4 & 1957.16 & 263 & $\mathrm{Ma}$ & Made land \\
\hline & 16 & Polygon & 35348.6 & 1246.45 & 267 & $\mathrm{Ma}$ & Made land \\
\hline & 17 & Polygon & 11754.1 & 544.865 & 269 & $\mathrm{Ma}$ & Made land \\
\hline & 18 & Polygon & 19447.2 & 750.782 & 270 & $\mathrm{Ma}$ & Made land \\
\hline & 19 & Polygon & 1886450 & 6522.26 & 276 & $\mathrm{Ca} / \mathrm{Ma}$ & Coastal beach \\
\hline & 20 & Polygon & 5487000 & 15291.9 & 310 & $\mathrm{Ma}$ & Made land \\
\hline & 21 & Polygon & 989023 & 4489.25 & 312 & $\mathrm{Ma}$ & Made land \\
\hline & 22 & Polygon & 4873.06 & 266.677 & 326 & $\mathrm{Ma}$ & Made land \\
\hline & 23 & Polygon & 43845.4 & 759.581 & 328 & $\mathrm{Ma}$ & Made land \\
\hline & 24 & Polygon & 136649 & 1491.29 & 342 & $\mathrm{Ma}$ & Made land \\
\hline & 25 & Polygon & 178171 & 1763.39 & 346 & $\mathrm{Ma}$ & Made land \\
\hline & 26 & Polygon & 110978 & 1475.71 & 349 & $\mathrm{Ma}$ & Made land \\
\hline & 27 & Polygon & 79559.7 & 1185.27 & 352 & $\mathrm{Ma}$ & Made land \\
\hline & 28 & Polygon & 223053 & 2350.32 & 359 & $\mathrm{Ma}$ & Made land \\
\hline & 29 & Polygon & 156886 & 1742.49 & 361 & $\mathrm{Ma}$ & Made land \\
\hline & 30 & Polygon & 112676 & 1417.49 & 363 & $\mathrm{Ma}$ & Made land \\
\hline & 31 & Polygon & 132257 & 1345.56 & 365 & $\mathrm{Ma}$ & Made land \\
\hline & 32 & Polygon & 523513 & 8237.58 & 376 & $\mathrm{Ma}$ & Made land \\
\hline & 33 & Polygon & 233799 & 2519.27 & 383 & $\mathrm{Ma}$ & Made land \\
\hline & 34 & Polygon & 275533 & 2877.42 & 388 & $\mathrm{Ma}$ & Made land \\
\hline & 35 & Polygon & 216379 & 1941.33 & 395 & $\mathrm{Ma}$ & Made land \\
\hline & 36 & Polygon & 56043.3 & 1043.65 & 410 & $\mathrm{Ma}$ & Made land \\
\hline & 37 & Polygon & 208847 & 2719.12 & 413 & $\mathrm{Ma}$ & Made land \\
\hline & 38 & Polygon & 14483.6 & 514.83 & 416 & $\mathrm{Ma}$ & Made land \\
\hline & 39 & Polygon & 829176 & 4346.19 & 420 & $\mathrm{Ma}$ & Made land \\
\hline
\end{tabular}

Table 5-B. Land Ownership Attribute Table

\begin{tabular}{|r|r|l|l|r|r|}
\hline & FID * & \multicolumn{1}{|c|}{ Shape * } & OWN_STATE & Shape_Length & \multicolumn{1}{c|}{ Shape_Area } \\
\hline 1 & Polygon & & 427903.683524 & 38840742.350615 \\
\hline & 2 & Polygon & FL & 11664.973101 & 733454.538715 \\
\hline
\end{tabular}


Table 6-B. Percent Imperviousness Attribute Table

\begin{tabular}{|c|c|c|c|}
\hline & Rowid & VALUE & COUNT \\
\hline - & 0 & 0 & 64921 \\
\hline & 1 & 1 & 362 \\
\hline & 2 & 2 & 301 \\
\hline & 3 & 3 & 216 \\
\hline & 4 & 4 & 204 \\
\hline & 5 & 5 & 200 \\
\hline & 6 & 6 & 175 \\
\hline & 7 & 7 & 144 \\
\hline & 8 & 8 & 152 \\
\hline & 9 & 9 & 166 \\
\hline & 10 & 10 & 131 \\
\hline & 11 & 11 & 149 \\
\hline & 12 & 12 & 133 \\
\hline & 13 & 13 & 140 \\
\hline & 14 & 14 & 136 \\
\hline & 15 & 15 & 152 \\
\hline & 16 & 16 & 190 \\
\hline & 17 & 17 & 162 \\
\hline & 18 & 18 & 196 \\
\hline & 19 & 19 & 178 \\
\hline & 20 & 20 & 210 \\
\hline & 21 & 21 & 219 \\
\hline & 22 & 22 & 179 \\
\hline & 23 & 23 & 208 \\
\hline & 24 & 24 & 205 \\
\hline & 25 & 25 & 219 \\
\hline & 26 & 26 & 252 \\
\hline & 27 & 27 & 246 \\
\hline & 28 & 28 & 261 \\
\hline & 29 & 29 & 253 \\
\hline & 30 & 30 & 248 \\
\hline & 31 & 31 & 288 \\
\hline & 32 & 32 & 280 \\
\hline & 33 & 33 & 286 \\
\hline & 34 & 34 & 317 \\
\hline & 35 & 35 & 320 \\
\hline & 36 & 36 & 293 \\
\hline & 37 & 37 & 322 \\
\hline & 38 & 38 & 275 \\
\hline & 39 & 39 & 315 \\
\hline & 40 & 40 & 312 \\
\hline & 41 & 41 & 362 \\
\hline & 42 & 42 & 342 \\
\hline & 43 & 43 & 308 \\
\hline & 44 & 44 & 355 \\
\hline & 45 & 45 & 352 \\
\hline & 46 & 46 & 326 \\
\hline & 47 & 47 & 311 \\
\hline & 48 & 48 & 356 \\
\hline & 49 & 49 & 318 \\
\hline & 50 & 50 & 314 \\
\hline
\end{tabular}


Table 6-B continued

\begin{tabular}{|c|c|c|c|}
\hline & 51 & 51 & 310 \\
\hline & 52 & 52 & 343 \\
\hline & 53 & 53 & 300 \\
\hline & 54 & 54 & 345 \\
\hline & 55 & 55 & 330 \\
\hline & 56 & 56 & 312 \\
\hline & 57 & 57 & 302 \\
\hline & 58 & 58 & 333 \\
\hline & 59 & 59 & 297 \\
\hline & 60 & 60 & 270 \\
\hline & 61 & 61 & 288 \\
\hline & 62 & 62 & 252 \\
\hline & 63 & 63 & 310 \\
\hline & 64 & 64 & 266 \\
\hline & 65 & 65 & 267 \\
\hline & 66 & 66 & 259 \\
\hline & 67 & 67 & 273 \\
\hline & 68 & 68 & 235 \\
\hline & 69 & 69 & 260 \\
\hline & 70 & 70 & 239 \\
\hline & 71 & 71 & 301 \\
\hline & 72 & 72 & 240 \\
\hline & 73 & 73 & 302 \\
\hline & 74 & 74 & 303 \\
\hline & 75 & 75 & 319 \\
\hline & 76 & 76 & 301 \\
\hline & 77 & 77 & 322 \\
\hline & 78 & 78 & 329 \\
\hline & 79 & 79 & 302 \\
\hline & 80 & 80 & 354 \\
\hline & 81 & 81 & 325 \\
\hline & 82 & 82 & 375 \\
\hline & 83 & 83 & 352 \\
\hline & 84 & 84 & 358 \\
\hline & 85 & 85 & 376 \\
\hline & 86 & 86 & 357 \\
\hline & 87 & 87 & 346 \\
\hline & 88 & 88 & 409 \\
\hline & 89 & 89 & 397 \\
\hline & 90 & 90 & 384 \\
\hline & 91 & 91 & 368 \\
\hline & 92 & 92 & 381 \\
\hline & 93 & 93 & 335 \\
\hline & 94 & 94 & 365 \\
\hline & 95 & 95 & 410 \\
\hline & 96 & 96 & 409 \\
\hline & 97 & 97 & 402 \\
\hline & 98 & 98 & 252 \\
\hline & 99 & 99 & 160 \\
\hline & 100 & 100 & 119 \\
\hline
\end{tabular}




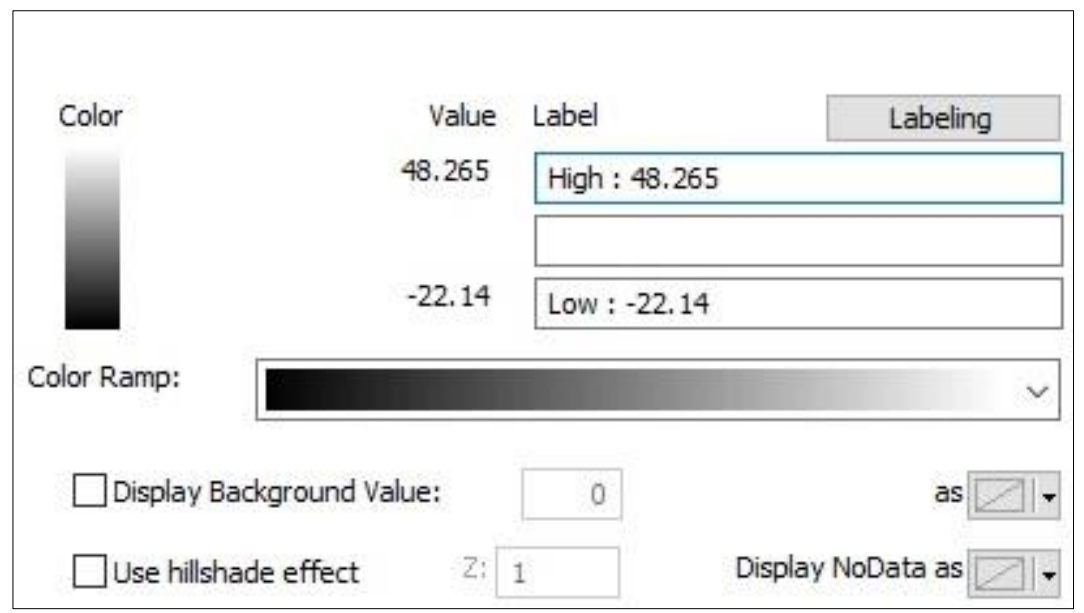

Figure 1-B. DEM Layer Properties 
Table 7-B. North Shore LIDI and GI Unite Area and Top Width

\begin{tabular}{|c|c|c|c|c|c|}
\hline 4 & ID & LID Type & Replicate & Unit Area & Top Width \\
\hline 1 & LID1 & 12: Green Roof & 1 & 3735.000 & 59.000 \\
\hline 2 & LID2 & 12: Green Roof & 1 & 2131.000 & 45.000 \\
\hline 3 & LID3 & 12: Green Roof & 1 & 2927.000 & 52.000 \\
\hline 4 & LID4 & 12: Green Roof & 1 & 7556.000 & 85.000 \\
\hline 5 & LID5 & 12: Green Roof & 1 & 6867.000 & 82.000 \\
\hline 6 & LID6 & 12: Green Roof & 1 & 7244.000 & 82.000 \\
\hline 7 & LID7 & 12: Green Roof & 1 & 3110.000 & 55.000 \\
\hline 8 & LID8 & 12: Green Roof & 1 & 2540.000 & 49.000 \\
\hline 9 & LID9 & 12: Green Roof & 1 & 5091.000 & 68.000 \\
\hline 10 & LID10 & 12: Green Roof & 1 & 4746.000 & 68.000 \\
\hline 11 & LID11 & 12: Green Roof & 1 & 3562.000 & 59.000 \\
\hline 12 & LID12 & 12: Green Roof & 1 & 3455.000 & 55.000 \\
\hline 13 & LID13 & 12: Green Roof & 1 & 2744.000 & 49.000 \\
\hline 14 & LID14 & 12: Green Roof & 1 & 5715.000 & 75.000 \\
\hline 15 & LID15 & 12: Green Roof & 1 & 2486.000 & 49.000 \\
\hline 16 & LID16 & 12: Green Roof & 1 & 1711.000 & 39.000 \\
\hline 17 & LID17 & 12: Green Roof & 1 & 3487.000 & 59.000 \\
\hline 18 & LID18 & 12: Green Roof & 1 & 5102.000 & 68.000 \\
\hline 19 & LID19 & 12: Green Roof & 1 & 5188.000 & 68.000 \\
\hline 20 & LID20 & 12: Green Roof & 1 & 4843.000 & 68.000 \\
\hline 21 & LID21 & 12: Green Roof & 1 & 3175.000 & 55.000 \\
\hline 22 & LID22 & 12: Green Roof & 1 & 1829.000 & 42.000 \\
\hline 23 & LID23 & 12: Green Roof & 1 & 904.000 & 29.000 \\
\hline 24 & LID24 & 12: Green Roof & 1 & 1862.000 & 42.000 \\
\hline 25 & LID25 & 12: Green Roof & 1 & 2841.000 & 52.000 \\
\hline 26 & LID26 & 12: Green Roof & 1 & 4391.000 & 65.000 \\
\hline 27 & LID27 & 12: Green Roof & 1 & 2647.000 & 65.000 \\
\hline 28 & LID28 & 12: Green Roof & 1 & 2120.000 & 49.000 \\
\hline 29 & LID29 & 12: Green Roof & 1 & 4316.000 & 45.000 \\
\hline 30 & LID30 & 12: Green Roof & 1 & 2572.000 & 42.000 \\
\hline 31 & LID31 & 12: Green Roof & 1 & 2292.000 & 65.000 \\
\hline 32 & LID32 & 12: Green Roof & 1 & 7879.000 & 49.000 \\
\hline 33 & LID33 & 12: Green Roof & 1 & 2981.000 & 45.000 \\
\hline 34 & LID34 & 12: Green Roof & 1 & 4865.000 & 88.000 \\
\hline 35 & LID35 & 12: Green Roof & 1 & 4843.000 & 52.000 \\
\hline 36 & LID36 & 12: Green Roof & 1 & 3100.000 & 68.000 \\
\hline 37 & LID37 & 12: Green Roof & 1 & 3283.000 & 68.000 \\
\hline 38 & LID38 & 12: Green Roof & 1 & 2723.000 & 52.000 \\
\hline 39 & LID39 & 12: Green Roof & 1 & 4424.000 & 52.000 \\
\hline 40 & LID 40 & 12: Green Roof & 1 & 2454.000 & 49.000 \\
\hline 41 & LID 41 & 12: Green Roof & 1 & 5252.000 & 65.000 \\
\hline 42 & LID 42 & 12: Green Roof & 1 & 5511.000 & 49.000 \\
\hline 43 & LID 43 & 12: Green Roof & 1 & 1808.000 & 72.000 \\
\hline 44 & LID 44 & 12: Green Roof & 1 & 2626.000 & 72.000 \\
\hline 45 & LID 45 & 12: Green Roof & 1 & 4876.000 & 39.000 \\
\hline 46 & LID 46 & 12: Green Roof & 1 & 5898.000 & 49.000 \\
\hline 47 & LID 47 & 12: Green Roof & 1 & 5769.000 & 68.000 \\
\hline 48 & LID 48 & 12: Green Roof & 1 & 14628.000 & 75.000 \\
\hline 49 & LID 49 & 12. Green Roof & 1 & 7330.000 & 75.000 \\
\hline 50 & LID50 & 12: Green Roof & 1 & 2271.000 & 118.000 \\
\hline
\end{tabular}

Table continues 
Table 7-B continued

\begin{tabular}{|c|c|c|c|c|c|}
\hline 51 & LID51 & 12: Green Roof & 1 & 957.000 & 85.000 \\
\hline 52 & LID52 & 12: Green Roof & 1 & 2152.000 & 45.000 \\
\hline 53 & LID53 & 12: Green Roof & 1 & 5446.000 & 29.000 \\
\hline 54 & LID54 & 12: Green Roof & 1 & 2055.000 & 45.000 \\
\hline 55 & LID55 & 12: Green Roof & 1 & 3283.000 & 72.000 \\
\hline 56 & LID56 & 12: Green Roof & 1 & 5360.000 & 42.000 \\
\hline 57 & LID57 & 12: Green Roof & 1 & 5155.000 & 55.000 \\
\hline 58 & LID58 & 12: Green Roof & 1 & 2228.000 & 72.000 \\
\hline 59 & LID59 & 12: Green Roof & 1 & 5392.000 & 68.000 \\
\hline 60 & LID60 & 12: Green Roof & 1 & 5059.000 & 45.000 \\
\hline 61 & LID61 & 12: Green Roof & 1 & 5295.000 & 72.000 \\
\hline 62 & LID62 & 12: Green Roof & 1 & 5155.000 & 68.000 \\
\hline 63 & LID63 & 12: Green Roof & 1 & 4811.000 & 72.000 \\
\hline 64 & LID64 & 12: Green Roof & 1 & 13991.000 & 72.000 \\
\hline 65 & LID65 & 12: Green Roof & 1 & 5640.000 & 68.000 \\
\hline 66 & LID66 & 12: Green Roof & 1 & 5328.000 & 68.000 \\
\hline 67 & LID67 & 12: Green Roof & 1 & 4154.000 & 118.000 \\
\hline 68 & LID68 & 12: Green Roof & 1 & 4714.000 & 72.000 \\
\hline 69 & LID69 & 12: Green Roof & 1 & 4962.000 & 72.000 \\
\hline 70 & LID70 & 13: Porous Pavement & 1 & 9827.000 & 65.000 \\
\hline 71 & LID71 & 13: Porous Pavement & 1 & 53863.000 & 68.000 \\
\hline 72 & LID72 & 13: Porous Pavement & 1 & 24380.000 & 98.000 \\
\hline 73 & LID73 & 13: Porous Pavement & 1 & 12410.000 & 229.000 \\
\hline 74 & LID74 & 13: Porous Pavement & 1 & 46801.000 & 154.000 \\
\hline 75 & LID75 & 13: Porous Pavement & 1 & 1237.000 & 108.000 \\
\hline 76 & LID76 & 13: Porous Pavement & 1 & 5080.000 & 213.000 \\
\hline 77 & LID77 & 13: Porous Pavement & 1 & 11948.000 & 32.000 \\
\hline 78 & LID78 & 13: Porous Pavement & 1 & 11808.000 & 68.000 \\
\hline 79 & LID79 & 2: Bio-Retention & 1 & 7050.000 & 108.000 \\
\hline 80 & LID80 & 2: Bio-Retention & 1 & 7846.000 & 88.000 \\
\hline 81 & LID81 & 2: Bio-Retention & 1 & 8116.000 & 88.000 \\
\hline 82 & LID82 & 2: Bio-Retention & 1 & 6092.000 & 75.000 \\
\hline 83 & LID83 & 2: Bio-Retention & 1 & 2421.000 & 49.000 \\
\hline 84 & LID84 & 8: Grassed Swale & 1 & 376.000 & 16.000 \\
\hline 85 & LID85 & 8: Grassed Swale & 1 & 613.000 & 22.000 \\
\hline 86 & LID86 & 8: Grassed Swale & 1 & 2034.000 & 42.000 \\
\hline 87 & LID87 & 8: Grassed Swale & 1 & 1323.000 & 36.000 \\
\hline 88 & LID88 & 8: Grassed Swale & 1 & 538.000 & 22.000 \\
\hline 89 & LID89 & 8: Grassed Swale & 1 & 1668.000 & 39.000 \\
\hline 90 & LID90 & 8: Grassed Swale & 1 & 710.000 & 26.000 \\
\hline 91 & LID91 & 8: Grassed Swale & 1 & 2906.000 & 52.000 \\
\hline 92 & LID92 & 8: Grassed Swale & 1 & 3067.000 & 52.000 \\
\hline 93 & LID93 & 8: Grassed Swale & 1 & 602.000 & 22.000 \\
\hline 94 & LID94 & 8: Grassed Swale & 1 & 516.000 & 45.000 \\
\hline 95 & LID95 & 8: Grassed Swale & 1 & 581.000 & 19.000 \\
\hline 96 & LID96 & 8: Grassed Swale & 1 & 2142.000 & 19.000 \\
\hline 97 & LID97 & 8: Grassed Swale & 1 & 398.000 & 16.000 \\
\hline 98 & LID98 & 8: Grassed Swale & 1 & 409.000 & 29.000 \\
\hline 99 & LID99 & 8: Grassed Swale & 1 & 279.000 & 32.000 \\
\hline 100 & LID100 & 8: Grassed Swale & 1 & 925.000 & 29.000 \\
\hline
\end{tabular}

\section{Table continues}


Table 7-B continued

\begin{tabular}{|l|l|l|r|r|r|}
\hline 101 & LID101 & 8: Grassed Swale & 1 & 1076.000 & 29.000 \\
\hline 102 & LID102 & 8: Grassed Swale & 1 & 1033.000 & 26.000 \\
\hline 103 & LID103 & 8: Grassed Swale & 1 & 742.000 & 13.000 \\
\hline 104 & LID104 & 8: Grassed Swale & 1 & 936.000 & 32.000 \\
\hline 105 & LID105 & 8: Grassed Swale & 1 & 699.000 & 16.000 \\
\hline 106 & LID106 & 8: Grassed Swale & 1 & 258.000 & 19.000 \\
\hline 107 & LID107 & 4: Rain Barrel & 33 & 81.000 & 1.000 \\
\hline
\end{tabular}




\section{APPENDIX C}

\section{LIDI and GI Design Guide}

TABLE / FIGURE

PAGE

Figure 1-C. Bioretention Cell Level 1 Design Criteria .................................................... 95

Figure 2-C. Bioretention Cell Level 2 Design Criteria .............................................. 95

Figure 3-C. Extensive and Intensive Green Roof Design Layers .................................. 96

Table 1-C. Extensive and Intensive Green Roof Features ........................................... 96

Figure 4-C. Grassed Swale Design Criteria (with Underdrain) ................................... 97

Figure 5-C. Grassed Swale Underdrain Details ..................................................... 97

Figure 6-C. Grassed Swale Design Criteria (without Underdrain) ................................97

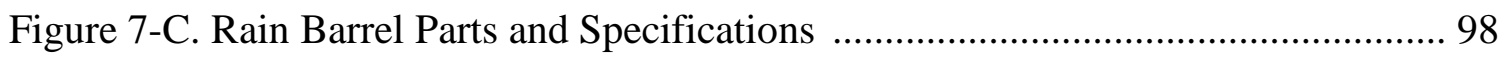

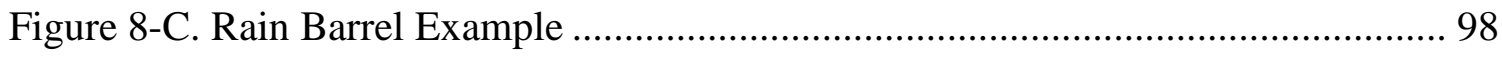

Figure 9-C. Porous Pavement Design Layers ....................................................... 99

Table 2-C. Comparative Properties of the Three Major Porous Pavement Types......... 99 


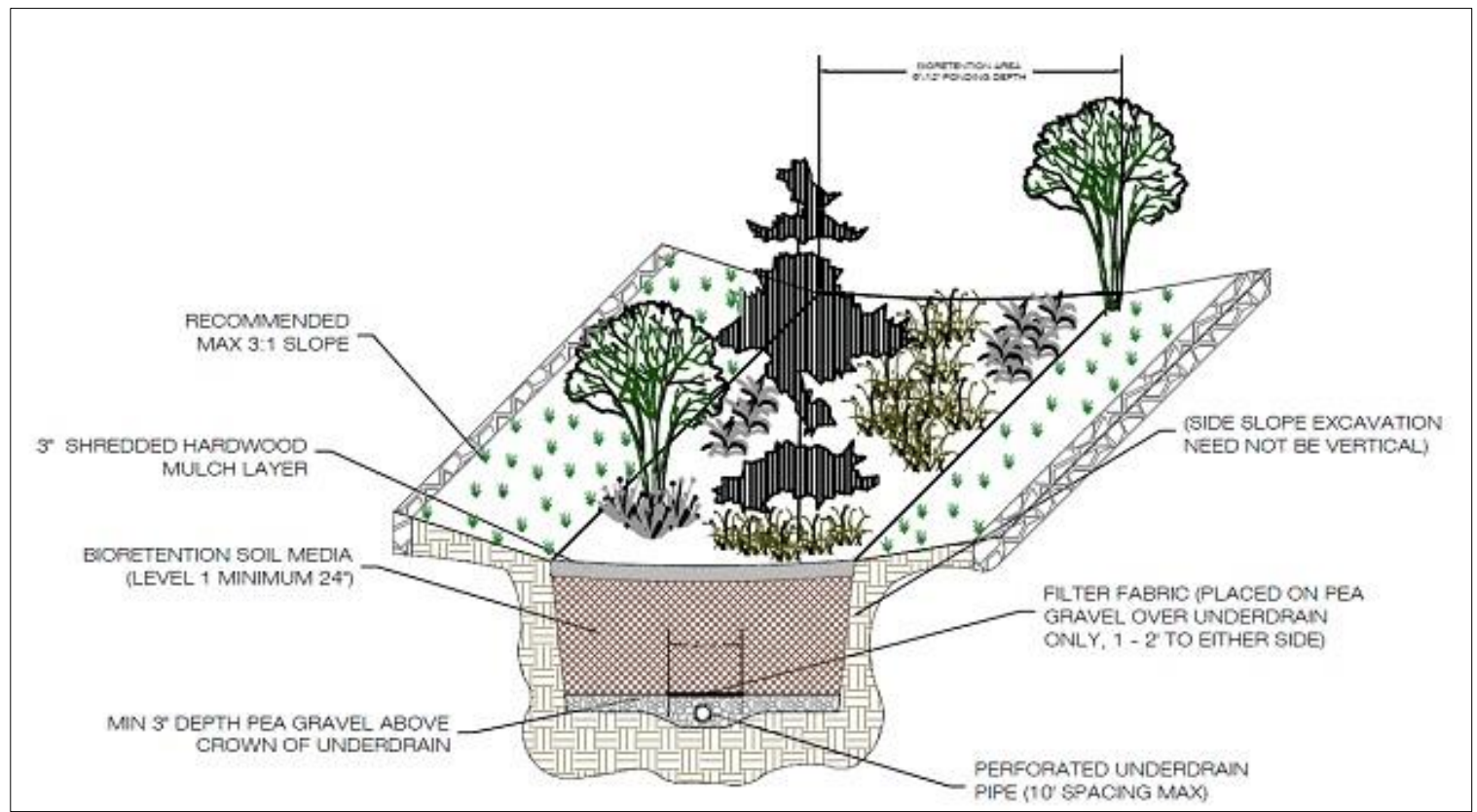

Figure 1-C. Bioretention Cell Level 1 Design Criteria [49]

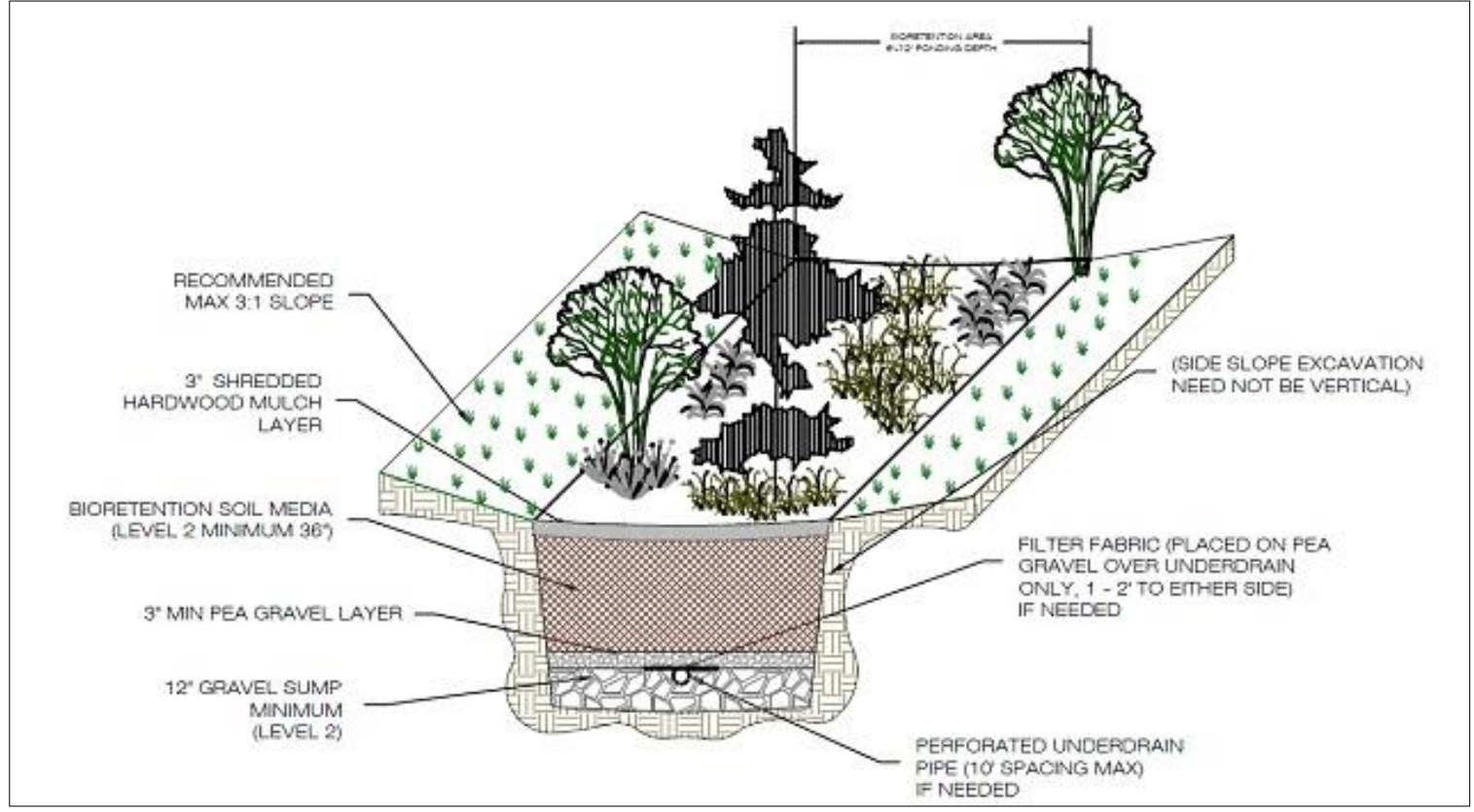

Figure 2-C. Bioretention Cell Level 2 Design Criteria [49] 


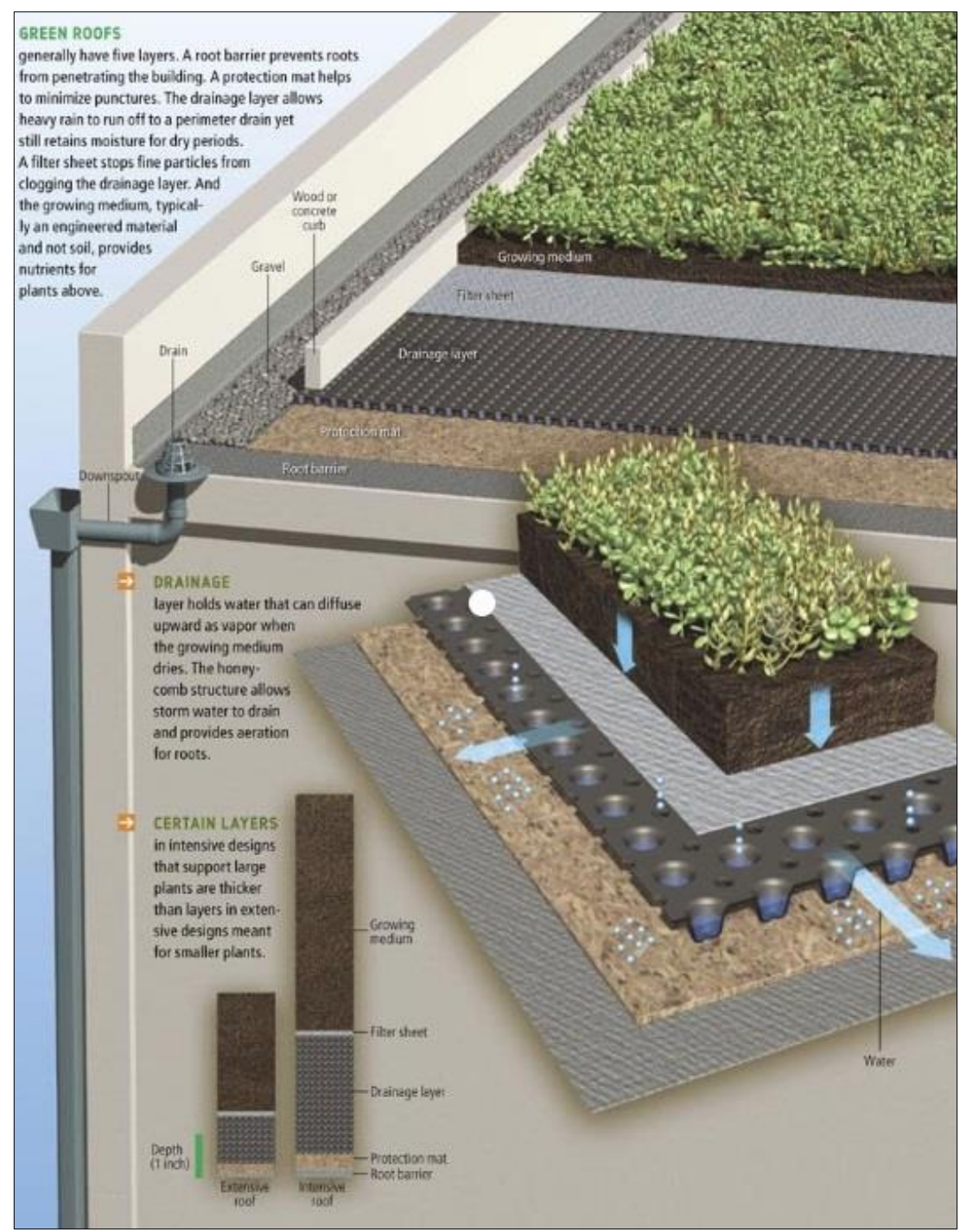

Figure 3-C. Extensive and Intensive Green Roof Design Layers [52]

Table 1-C. Extensive and Intensive Green Roof Features [52]

\begin{tabular}{|l|l|l|}
\hline Feature & Extensive & Intensive \\
\hline Growing medium & $2-6$ inches & $\begin{array}{l}6-15 \text { inches } \\
\text { and deeper }\end{array}$ \\
\hline Weight & $13-50 \mathrm{lbs} / \mathrm{sf}$ & $50+\mathrm{bs} / \mathrm{sf}$ \\
\hline Plants & $\begin{array}{l}\text { Low growing plants: } 1-24 \\
\text { inches high }\end{array}$ & Trees, shrubs, and more \\
\hline Water requirements & Low water requirements & Irrigation usually necessary \\
\hline Maintenance & Minimal maintenance & High maintenance \\
\hline
\end{tabular}




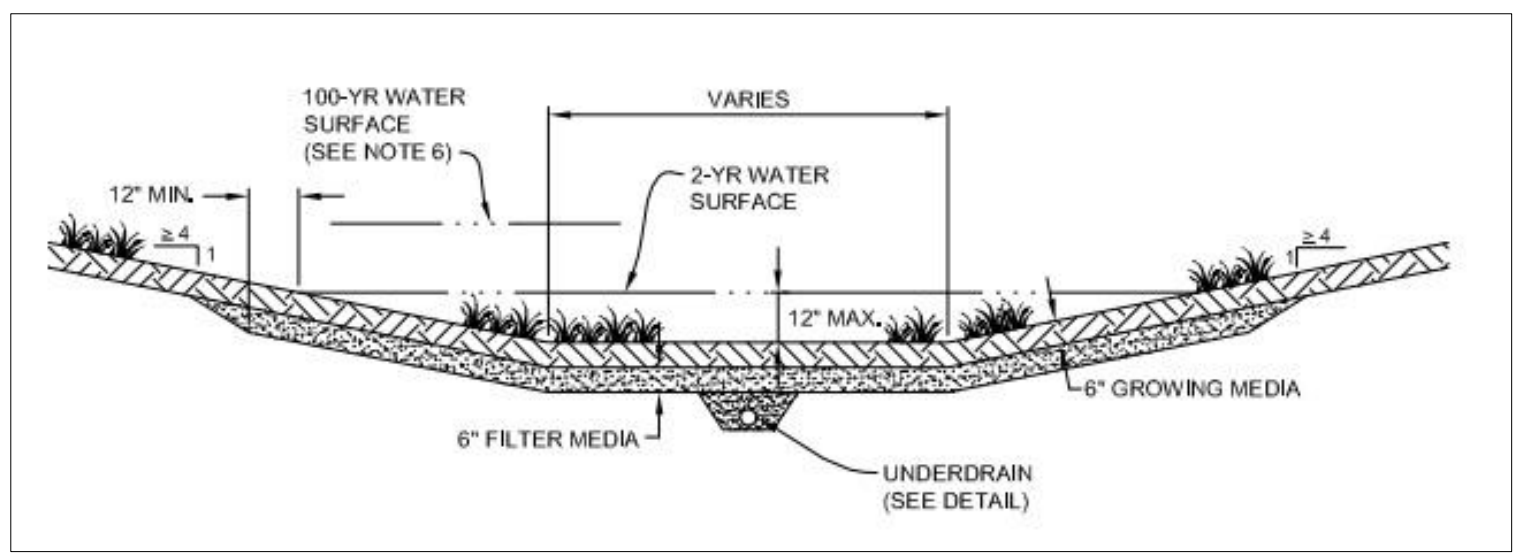

Figure 4-C. Grassed Swale Design Criteria (with Underdrain) [53]

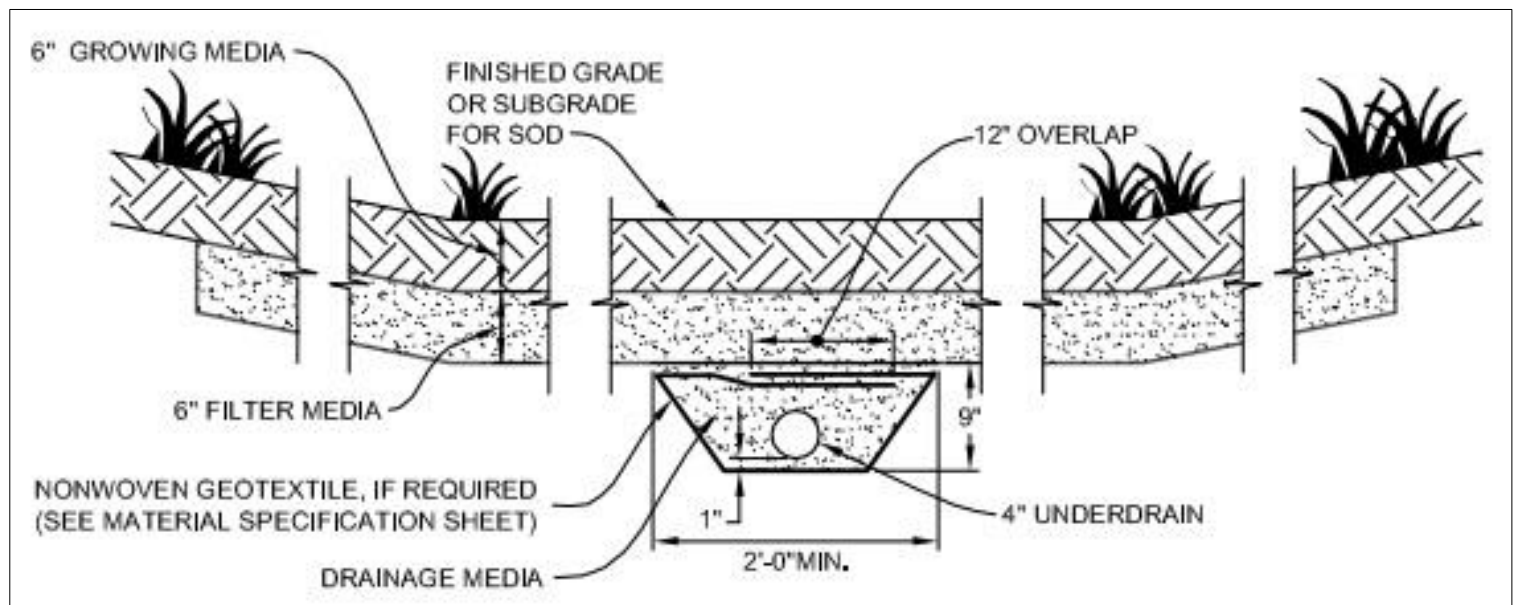

Figure 5-C. Grassed Swale Underdrain Details [53]

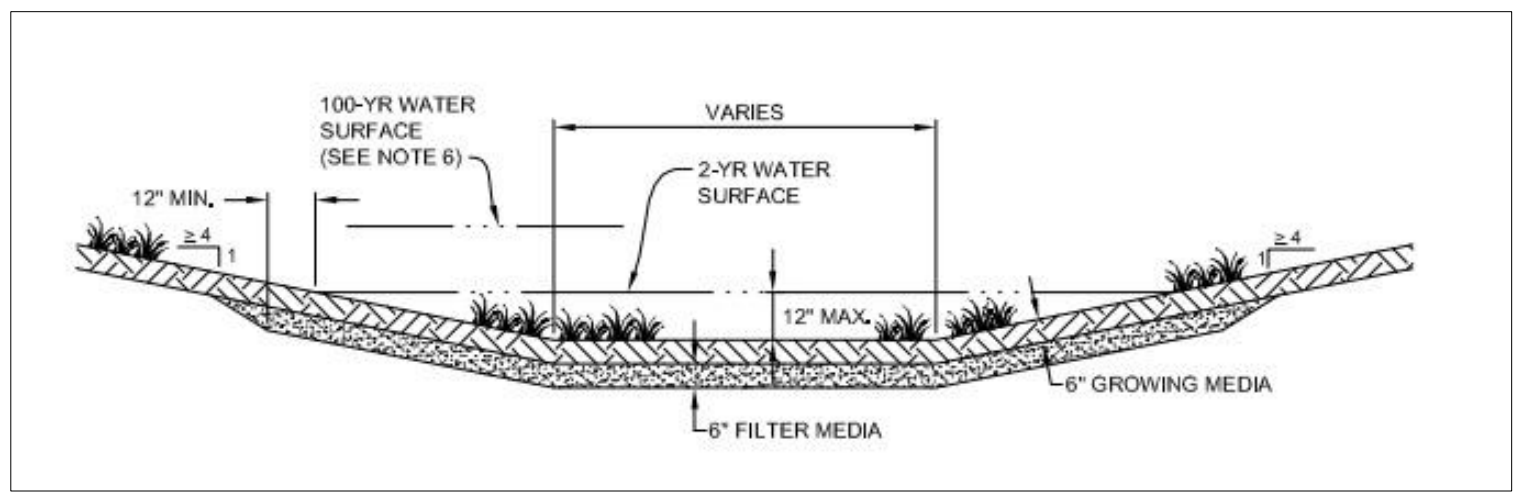

Figure 6-C. Grassed Swale Design Criteria (without Underdrain) [53] 


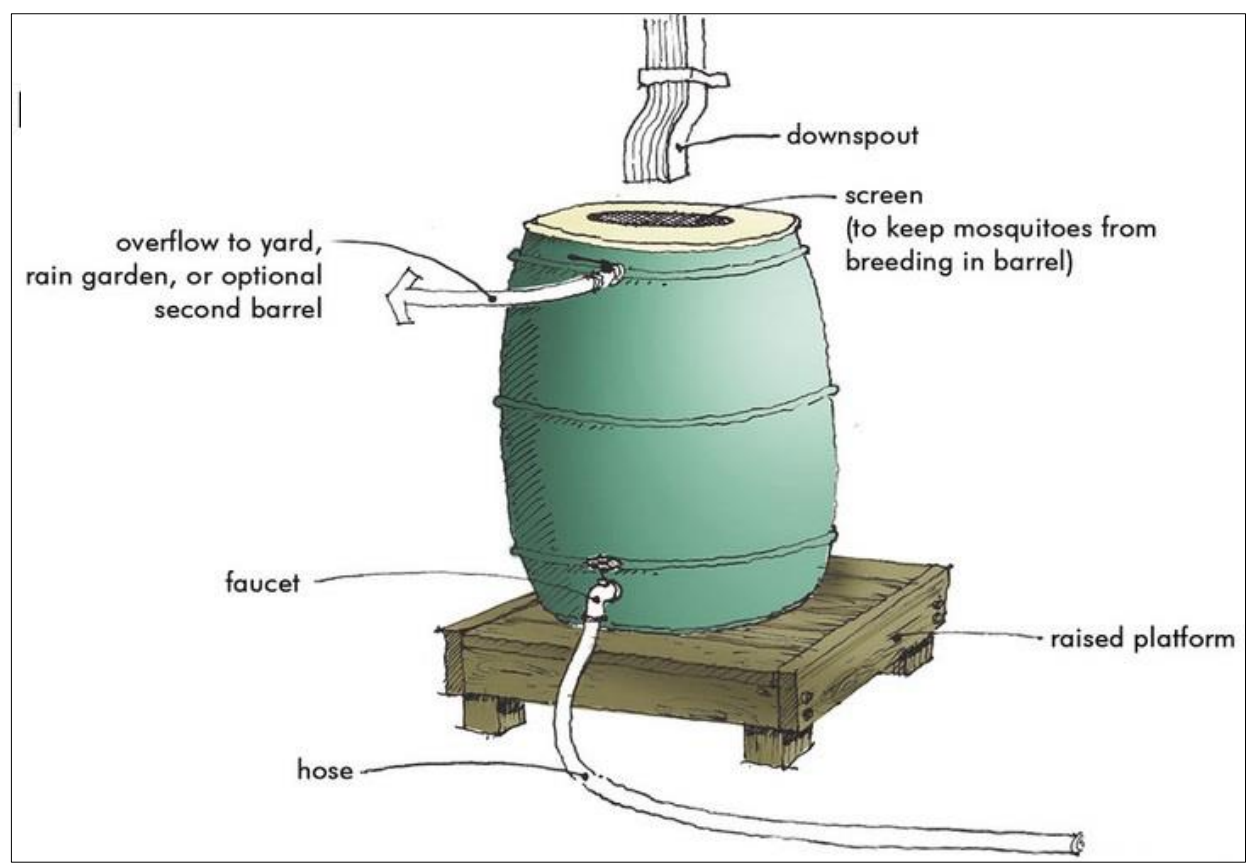

Figure 7-C. Rain Barrel Parts and Specification [54]

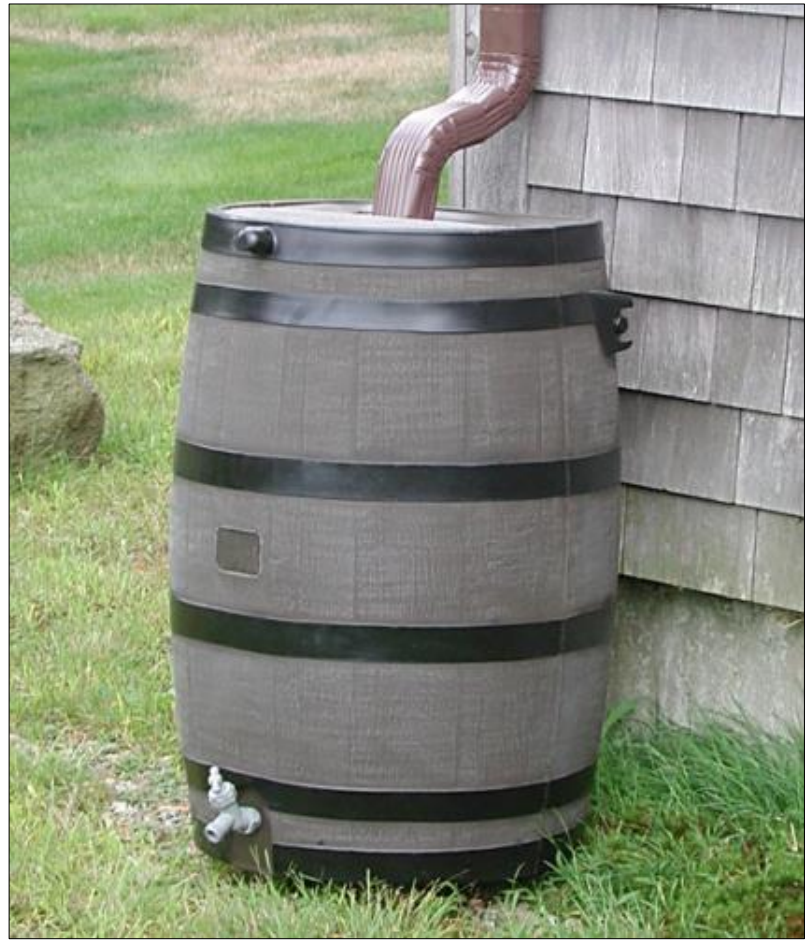

Figure 8-C. Rain Barrel Example [55] 


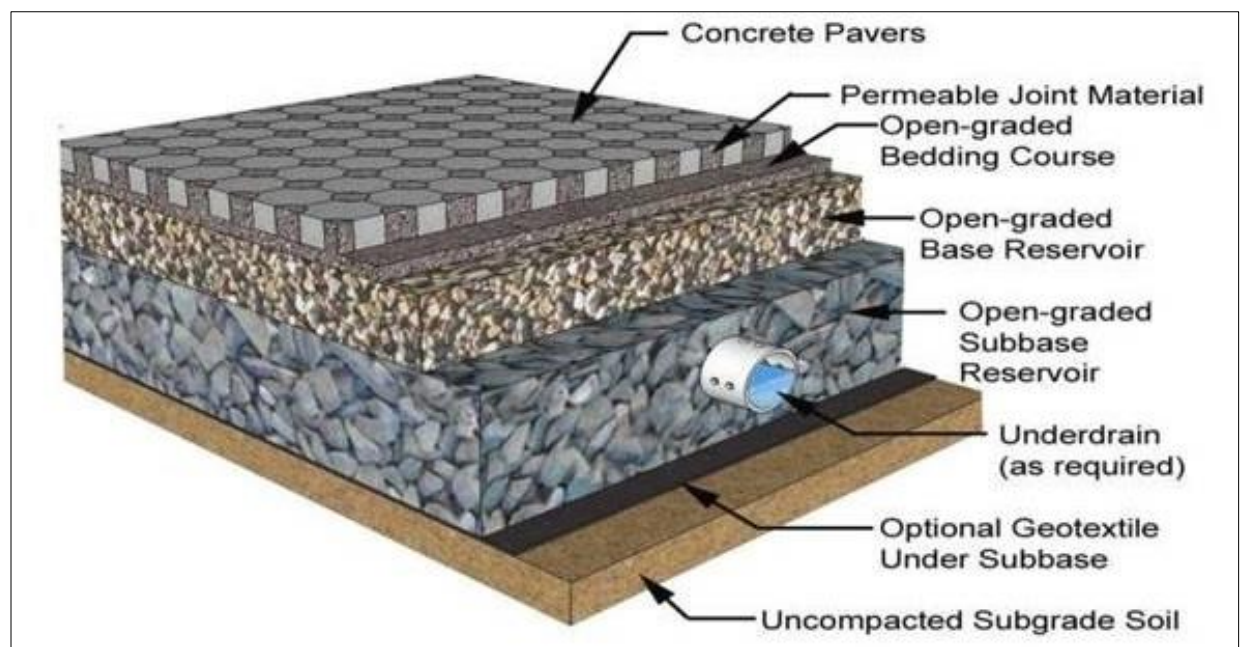

Figure 9-C. Porous Pavement Design Layers [50]

Table 2-C. Comparative Properties of the Three Major Porous Pavement Types [50]

\begin{tabular}{|l|l|l|l|}
\hline Design Factor & Porous Concrete & Porous Asphalt & Interlocking Pavers \\
\hline Pavement thickness & $5-8$ inches & $3-4$ inches & 3 inches \\
\hline Bedding layer & None & 2 inches of No. 57 stone $^{2}$ & $\begin{array}{l}2 \text { inches of No. } 8 \\
\text { stone }^{2}\end{array}$ \\
\hline Reservoir $^{1}$ & No. 57 stone & No. 2 stone $^{2}$ & $\begin{array}{l}\text { No. } 2 \text { stone }^{2} \\
3-4 \text { inches of No. } 57_{\text {stone }^{2}}\end{array}$ \\
\hline
\end{tabular}

${ }^{1}$ The thickness of the reservoir layer is determined by runoff storage needs, the infiltration rate of in situ soils, structural requirements of the pavement sub-base, depth to water table and bedrock, and frost depth conditions.

${ }^{2}$ Stone sizes correspond to ASTM D 448: Standard Classification for Sizes of Aggregate for Road and Bridge Construction. 